\title{
WestVirginiaUniversity
}

THE RESEARCH REPOSITORY @ WVU

Graduate Theses, Dissertations, and Problem Reports

2014

\section{The Influence of 4-H Judging Team Participation on Career Life Skills Development}

\author{
Evan $\mathrm{H}$. Anderson \\ West Virginia University
}

Follow this and additional works at: https://researchrepository.wvu.edu/etd

\section{Recommended Citation}

Anderson, Evan H., "The Influence of 4-H Judging Team Participation on Career Life Skills Development" (2014). Graduate Theses, Dissertations, and Problem Reports. 754.

https://researchrepository.wvu.edu/etd/754

This Thesis is protected by copyright and/or related rights. It has been brought to you by the The Research Repository @ WVU with permission from the rights-holder(s). You are free to use this Thesis in any way that is permitted by the copyright and related rights legislation that applies to your use. For other uses you must obtain permission from the rights-holder(s) directly, unless additional rights are indicated by a Creative Commons license in the record and/ or on the work itself. This Thesis has been accepted for inclusion in WVU Graduate Theses, Dissertations, and Problem Reports collection by an authorized administrator of The Research Repository @ WVU. For more information, please contact researchrepository@mail.wvu.edu. 
The Influence of 4-H Judging Team Participation on Career Life Skills Development

Evan H. Anderson

Thesis submitted to the Davis College of Agriculture, Natural Resources and Design at West Virginia University in partial fulfillment of the requirements

for the degree of

\section{Master of Science}

in

Agricultural and Extension Education

Deborah A. Boone, Ph.D., Chair

Harry N. Boone, Jr., Ph.D.

Jean M. Woloshuk, Ed.D.

Division of Resource Management

Morgantown, West Virginia

2014

Keywords: 4-H, Judging teams, Life skills, Career skills, Agriculture 


\section{ABSTRACT \\ The Influence of 4-H Judging Team Participation on Career Life Skills Development Evan H. Anderson}

The purpose of the study was to determine whether participation in WV 4-H agricultural judging teams impacted life skills development. This study measured the current life skill abilities of past 4-H state judging team winners from 1995 to 2006, determined their perception of the influence involvement on a judging team had on that ability, and compared that with the importance of the various life skills in participants' current jobs. A descriptive survey was sent to the target population, who were winners of West Virginia state 4-H agricultural judging team competitions between the years of 1995 and 2006 and competed in the national contest. 4-H judging team participation was found to influence education and career decisions and positively affect development of life skills, including many of those that respondents listed as being highly important in their current jobs. Problem solving, self-motivation, and self-responsibility were seen as having the highest importance in jobs; beyond these, $4-\mathrm{H}$ judging teams also developed skills in learning to learn, teamwork, and decision making. 


\section{ACKNOWLEDGEMENTS}

Many thanks are due to all those who helped me complete this thesis. Thanks to:

Dr. Debby Boone, my advisor. I simply could not have hoped for a better one.

Dr. Harry Boone, who is incredibly dedicated, knowledgeable, and a genuinely good person.

Dr. Jean Woloshuk, without whose previous work, help, and suggestions this thesis would not have existed at all.

My parents, for their constant love and support.

My friends, for the same.

And to all those who answered my survey, thank you for taking the time to do so. It is tremendously appreciated. 


\section{TABLE OF CONTENTS}

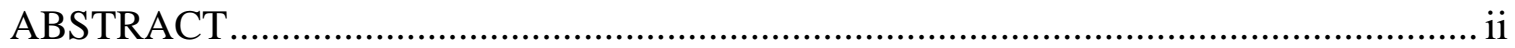

ACKNOWLEDGEMENTS ............................................................................... ii

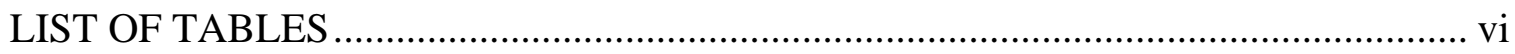

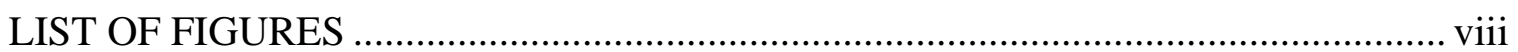

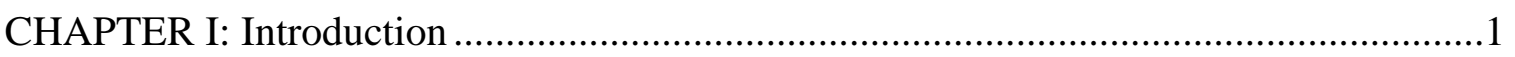

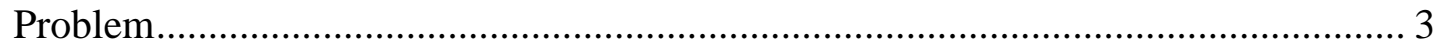

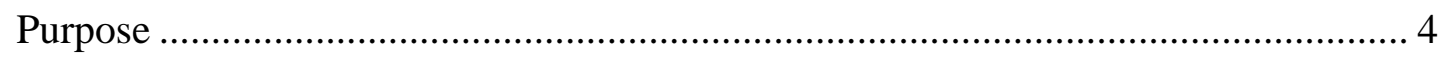

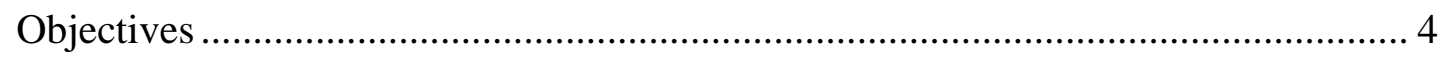

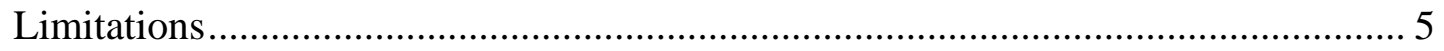

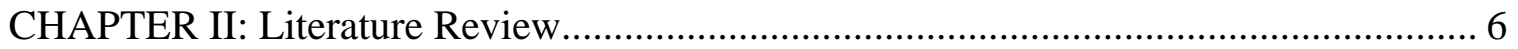

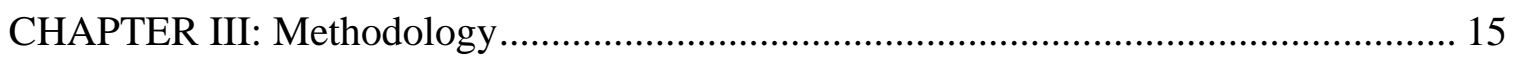

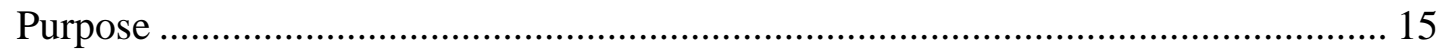

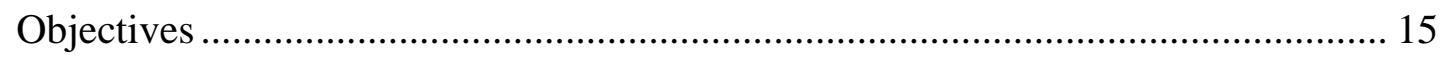

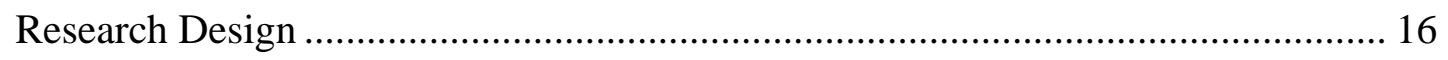

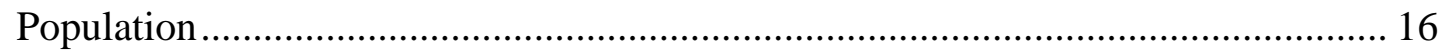

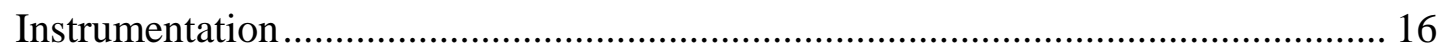

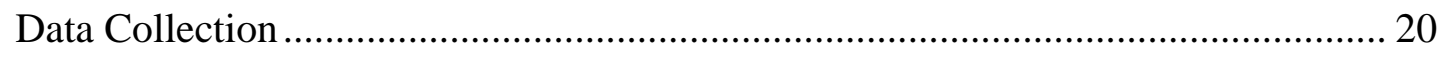

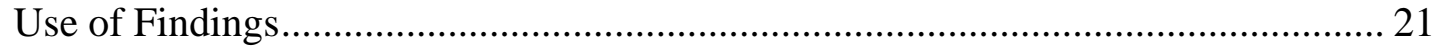

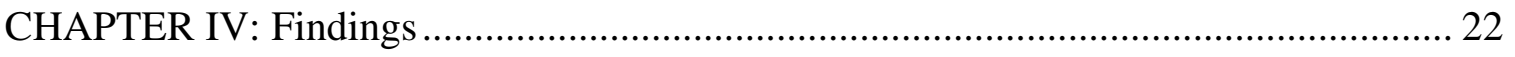

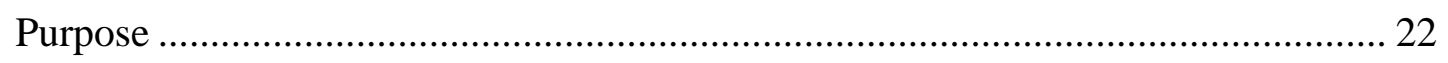

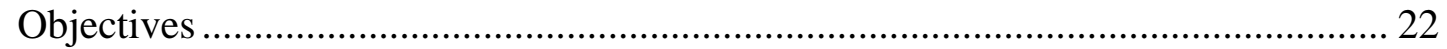

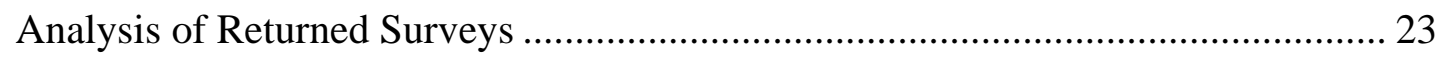

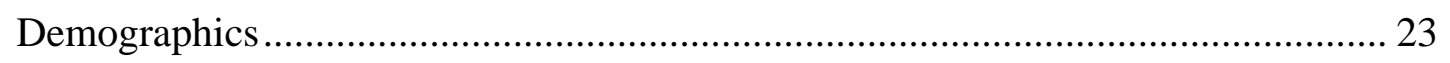

Judging Team Practices and Experiences............................................................... 29

Influence of Judging Team Participation on Education and Career Choice.............. 37

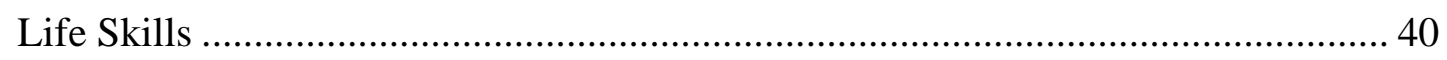

CHAPTER V: Summary, Conclusions, and Recommendations .................................. 72

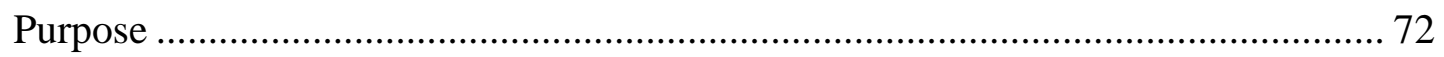

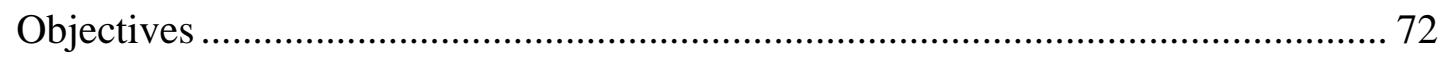

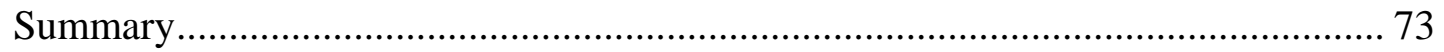




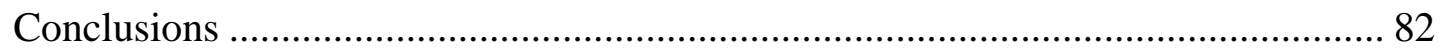

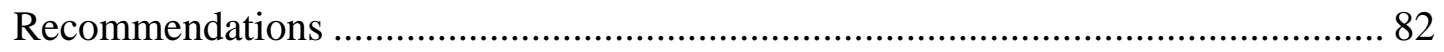

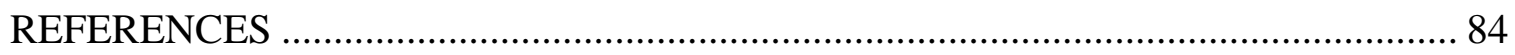

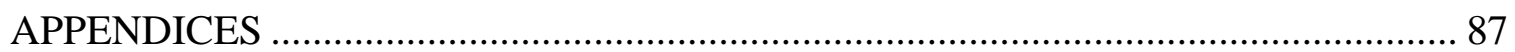

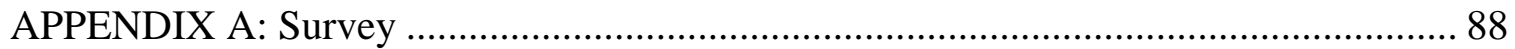

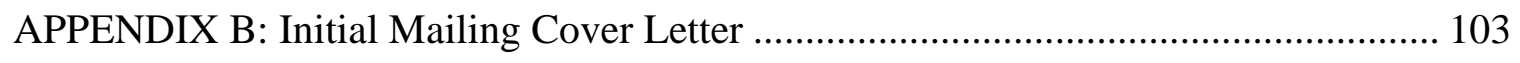

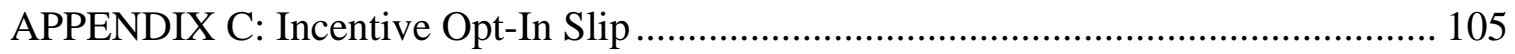

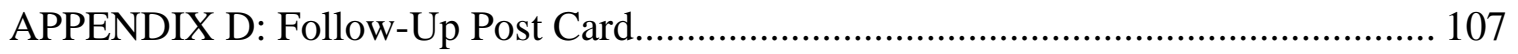

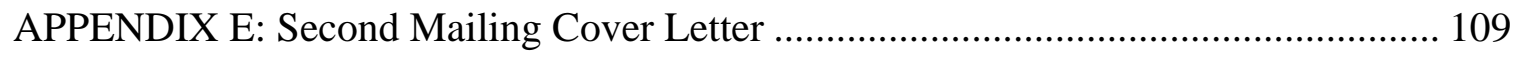

APPENDIX F: Second Follow-Up Post Card ......................................................... 111

APPENDIX G: Responses to Open-Ended Questions................................................ 113

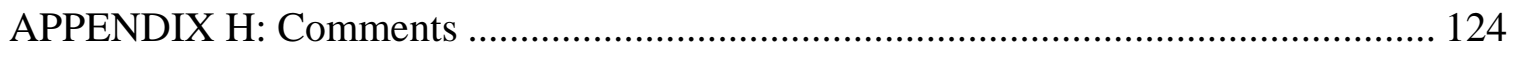

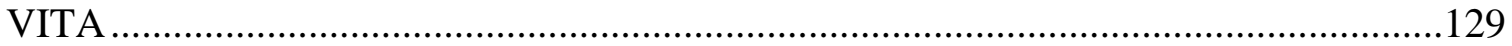




\section{LIST OF TABLES}

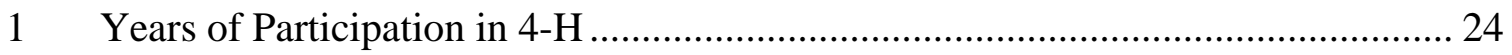

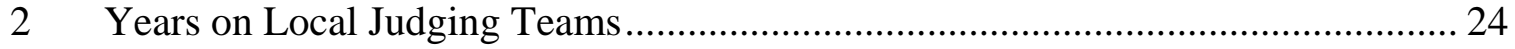

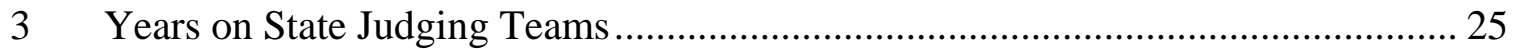

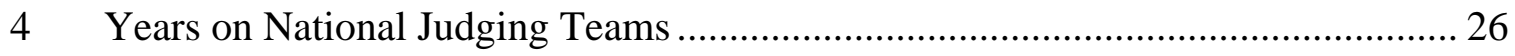

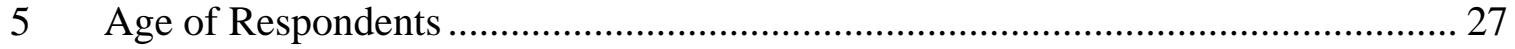

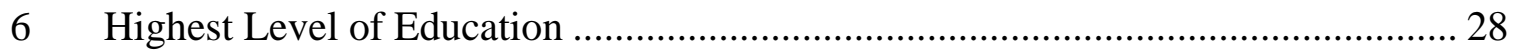

7 Jobs Related to Agriculture and Desire to Remain in Current Career .................... 29

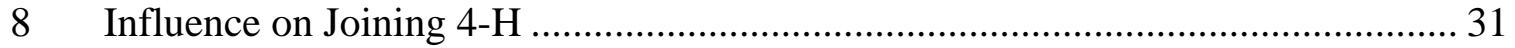

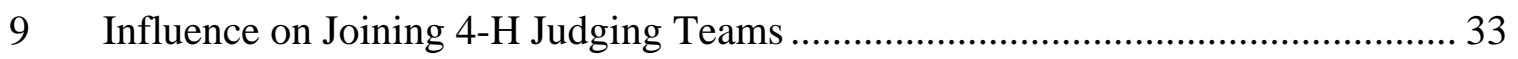

10 Individuals Who Taught Respondents 4-H Judging Skills ................................... 34

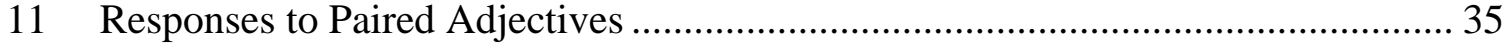

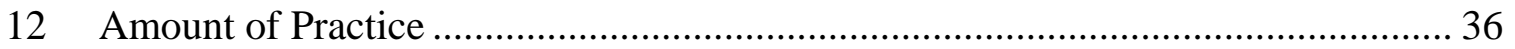

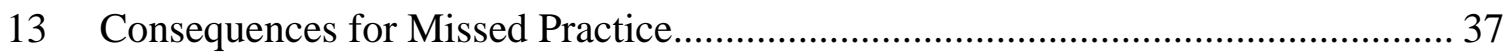

14 Judging Team Influence on Education and Career Choice.................................... 39

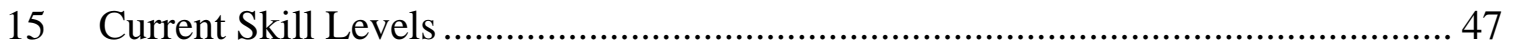

16 Influence of 4-H Judging Team Participation on Development of Life Skills ........ 58

17 Importance of Life Skills in Respondents’ Current Jobs ....................................... 69 


\section{LIST OF FIGURES}

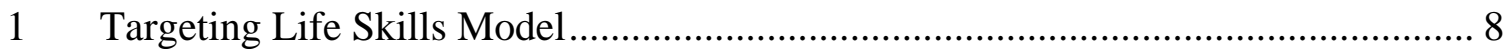

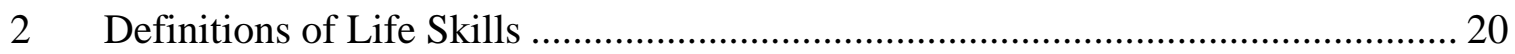

3 Judging Team Influence on Education and Career Choice................................... 75

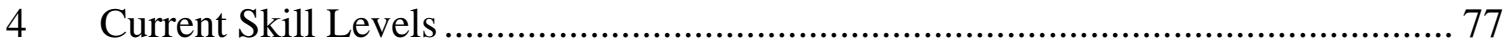

5 4-H Judging Team Influence on Development of Life Skills ............................... 79

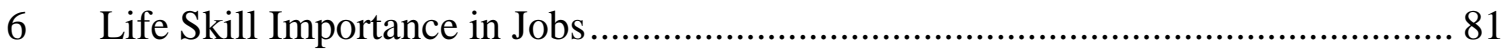




\section{CHAPTER I}

\section{Introduction}

Founded in 1902, 4-H is the youth development component of the Cooperative Extension Service. Initially, 4-H clubs were developed for youth in an effort to expose farmers and homemakers to new ways of doing things through teaching new information, skills and practices to rural youth, who in turn would share the information with their parents. The 4-H program is now active in urban areas as well and offers a wide range of agriculturally related educational programs and activities. In West Virginia alone, up to 15,000 youth are enrolled as organized club members annually and take part in programs that include 4-H projects, agriculturally related programs and activities, opportunities for civic engagement, and judging teams (National 4-H, April 9, 2014; personal conversation with Jean Woloshuk, March 1, 2014). The most popular activities among members of 4-H clubs were investigated by Ladewig and Thomas (1986), who looked at the impact of 4-H on its members nationally. While this study found that community and school clubs were the most popular form of participation in 4-H, 71 percent reported participating in stock shows and 60 percent in various contests, including judging contests.

One of 4-H’s primary goals is programming for positive development of youth, therefore, it is designed to give youth the opportunity to improve life skills. This is ultimately intended to better prepare individuals for further education and eventually entering the workforce. Many of the life skills developed as a result of involvement with 4-H programs are relevant to a broad range of careers, not only those directly related to agriculture. Gaining and improving skills such as leadership, communication, critical 
thinking, problem solving, self-responsibility, cooperation, and teamwork can serve to give an individual a strong foundation for further growth and development.

Judging teams are a part of the 4-H curriculum that helps to build life skills. Arising as part of the early 4-H club work, judging teams were noted to have begun prior to 1921 (True, 1928). In West Virginia, participants may currently compete on eight different judging teams: homesite evaluation, livestock, poultry, dairy cattle, forestry, horse, land, and horticulture judging. While these categories focus on different agricultural aspects, the steps used in evaluation are all very similar. Participants develop a variety of life skills while studying for and participating as members of judging teams.

4-H agricultural judging teams are intended to provide a safe, positive environment for individuals to learn and develop life skills. Judging teams emphasize experiential activities, organization, allowing youth to take part in leadership activities, and providing opportunities for volunteers to act as mentors to youths (WVU Extension, n.d.).

While the costs of offering judging programs may seem high, justification for their continuance may be found, in part, in the opportunities for development of life skills offered to participants. The life skills learned carry over to future education and occupational performance. Furthermore, the existence of judging teams at a collegiate level may influence potential students in deciding whether or not to attend a particular school (McCann \& McCann, 1992).

There seems to be no question that 4-H and its associated educational programming develop life skills in youth. Judging teams, animal and livestock projects, camps, and 4-H in general have all been the focus of studies that have shown that youth 
participants develop a variety of skills. Leadership, communication, self-confidence, responsibility, and decision-making are just a few of those that are taken away by 4- $\mathrm{H}$ members. What is much less prevalent among the body of research on these topics is a connection to the jobs these youths go on to later in life. One study by Robinson (2006) looked at employability skills of graduates from a school of Agriculture, Food, and Natural Resources, but more research is needed in this area. How helpful do past participants in 4-H judging teams find the life skills they developed as a result of their involvement to be useful in their current jobs?

\section{Problem}

As many as 15,000 West Virginia youth are members of the 4-H program each year, and of those approximately 475 are participants on judging teams. Participation on 4-H judging teams are intended to teach youth not only the skills directly related to judging, but also life skills such as leadership, communication, and self-confidence. These and other life skills as defined in the Targeting Life Skills Model by Hendricks (1996) are valuable to individuals throughout their lives and developing them is important to ensure that youth will have the ability to be effective in their future careers. Research has shown that 4-H, 4-H judging teams, and similar activities positively impact the development of life skills (Boyd, Herring, \& Briers, 1992; Ladewig \& Thomas, 1987; Lerner \& Lerner, 2013; McCann \& McCann, 1992; Rusk, Martin, Talbert, \& Balschweid, 2002). Further investigation is necessary, however, to determine the perceived importance of the life skills learned in conjunction with 4-H judging teams. Research is also needed to link the life skills used in developing 4-H programs to their usefulness in 
jobs, and to determine the impact of these life skills on the career paths participants choose later in their lives.

\section{Purpose}

The purpose of this study was to determine how participation in West Virginia 4-H agricultural judging teams impacts life skills development. This study intends to determine the current life skill abilities of past 4-H state judging team winners from 1995 to 2006, determine how they perceive that ability was influenced by involvement on a judging team, and compare that with the importance of the various life skills in former participants' current jobs.

\section{Objectives}

The objectives of the study were:

1. To describe how participating as a part of a West Virginia 4-H state agricultural judging team impacts the development of life skills.

2. To describe how past West Virginia state 4-H judging team participants perceive their current level of life skill development.

3. To determine past West Virginia state 4-H judging teams members' perceived importance of various life skills to their current job.

4. To describe how the life skills model used in 4-H programming relates to skills needed in employment situations. 


\section{Limitations}

This study was limited to the winners of West Virginia state 4-H agricultural judging team competitions between the years of 1995 and 2006 and competed in the national contest. Individuals who won the state competition and did not attend or declined to participate in the national competition were excluded from this study. 


\section{CHAPTER II}

\section{Literature Review}

A review of literature found that numerous research studies pertaining to life skill development in youth have used various lists of life skills. Among the life skills typically examined in studies are leadership (Astroth, 1996; Garton, Miltenberger, \& Pruett, 2007; Seevers \& Dormody, 1995; Singletary, Smith, \& Evans, 2006; Walker, 2003), communication skills (Boyd, Herring, \& Briers, 1992; Fitzpatrick, Gagne, Jones, Lobley, \& Phelps, 2005; Guthrie, 1997; McCann \& McCann, 1992; Shurson \& Lattner, 1991; Woloshuk, Kerns, \& Pennington, 1994), self-confidence (Armstrong, 2010; Fox, Schroeder, \& Lodl, 2003; Guthrie, 1997; McCann \& McCann, 1992; Rusk, SummerlotEarly, Machtmes, Talbert, \& Balschweid, 2003), and decision making (Guthrie, 1997; McCann \& McCann, 1992; Potter \& Mulroy, 1994; Rusk et al., 2003). Much less common was literature that connected the development of life skills to their applications later on, such as in a job or career.

With a primary focus on youth development in 4-H programming, Hendricks (1996) developed the “Targeting Life Skills Model” which highlights the four H’s (head, heart, hands, and health) and classifies a variety of life skills related to each. This Targeting Life Skills Model was developed to assist programmers in the development of their educational content, and comprises a comprehensive list of the life skills on which any particular program might focus. The life skills examined in other research may also be framed within this model.

The Targeting Life Skills Model listed various life skills under broad headings related to the four H's (hands, health, head and heart). Life skills listed under the heading 
of "hands" includes those related to giving and working, such as leadership, teamwork, and self-motivation. "Health" includes those related to being and living; including selfesteem, self-responsibility, self-discipline, and stress management. "Head" contains the subcategories of thinking and managing, which includes decision making, problem solving, critical thinking, and goal setting. Lastly, "heart” deals with relating and caring, and includes the skills related to empathy, conflict resolution, social skills, and communication (see Figure 1). The development of life skills have been researched in a number of studies, and while research specifically on judging teams is limited, other related activities have been investigated.

McCann and McCann (1992) surveyed 4-H judging team alumni in an attempt to determine the value of judging team programs. They found that judging team participation helped participants by developing communication skills, confidence, and decision making skills. Judging team programs were found to have influenced $44 \%$ of participants' choice of college.

Woloshuk, Kerns, and Pennington (1994) researched the impact of 4-H agricultural judging programs in West Virginia on their members. Participants, parents and guardians, and team coaches all had positive perceptions of the programs. Judging teams were found to provide opportunities for participants to gain communication, decision-making, problem solving, and organizational skills. 


\section{Targeting Life Skills Model}

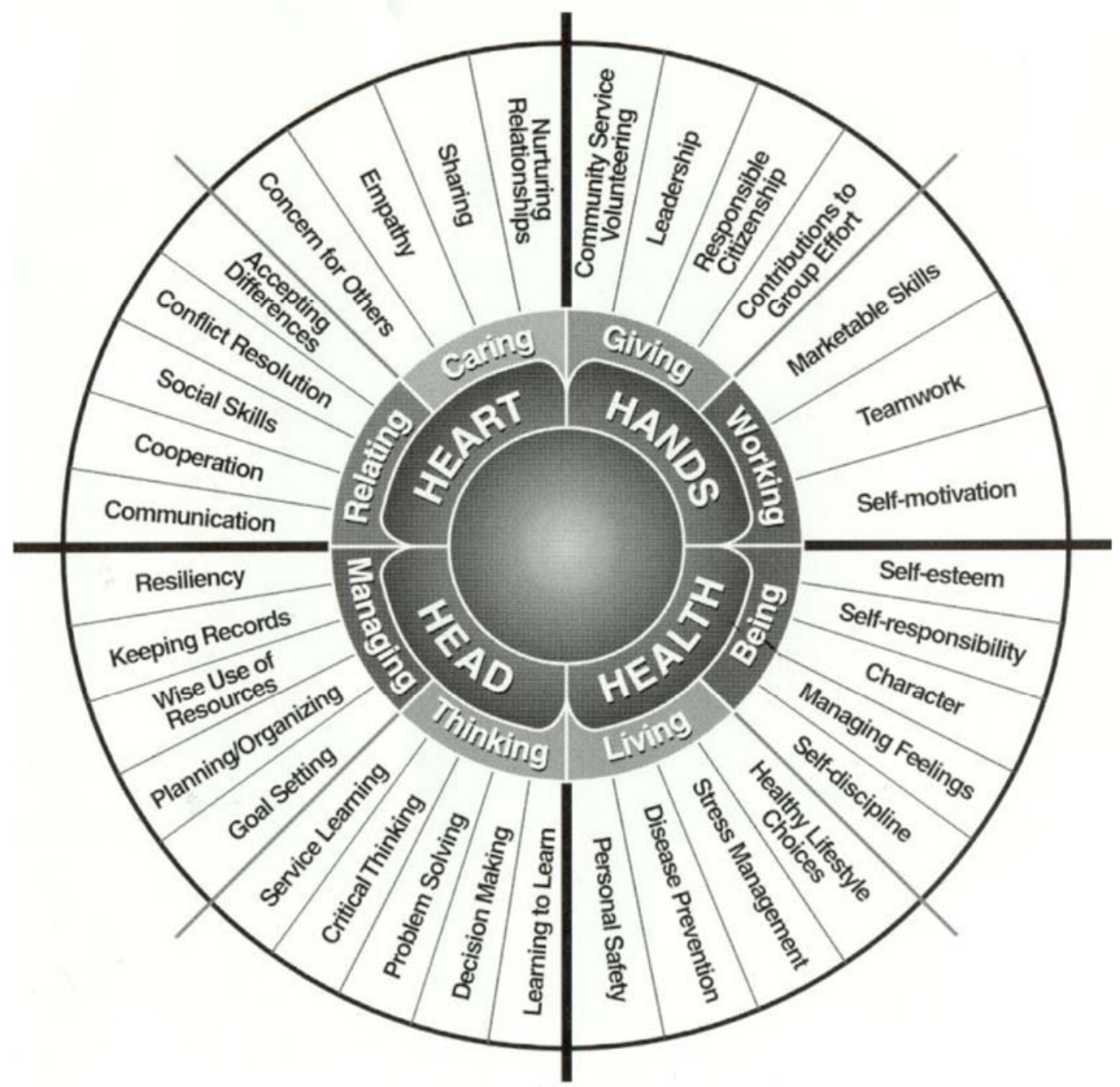

Figure 1

Targeting Life Skills Model (Hendricks, 1996. Used by permission of Iowa State University Extension and Outreach.)

Rusk, Martin, Talbert, and Balschweid (2002) conducted a study in Indiana to determine the effects of their livestock judging program on 10 life skills associated with workforce preparedness. Alumni of the livestock judging program, primarily between the ages of 21 and 50, responded that it was highly influential in developing their ability to 
verbally defend a position, livestock industry knowledge, oral communication, and decision making. The same 10 life skills were studied in Idaho in a study looking at 4-H animal judging. Of the respondents $97 \%$ of the judging alumni indicated that their experience in the Idaho 4-H animal judging program influenced their personal success. The life skills identified to have been most influenced by involvement were animal industry knowledge, self-confidence, decision making, and the ability to verbally defend a decision (Nash \& Sant, 2005).

Seevers and Dormody (1995) studied predictors of leadership life skill development in youth. Their study looked at 400 senior 4-H members and the development of their leadership skills and which activities most contributed to that development. Participation in leadership activities, which included judging contests, was found to be the most significant predictor of life skill development.

Leadership was also examined by Singletary, Smith, and Evans (2006), focusing on volunteer leaders in Nevada. They were surveyed to determine their perceptions of the skills youth develop as participants in 4-H and those skills that volunteer leaders possess that most aid youth in positive development. Results showed that volunteer leaders valued the ability to ensure the physical and psychological safety of 4-H members, and that the youth participating in 4-H learned all of the 15 life skills in question, including communication skills, self-esteem, decision-making, public speaking, leadership, and goal setting.

A Montana study on leadership and its relation to 4-H involvement surveyed community leaders. Rural leaders who participated in 4- $\mathrm{H}$ as youths were compared with those who did not and the perceptions of participants on the level of leadership skill 
development acquired through 4-H was measured. The top contributions 4-H were perceived to have had were teaching a person how to participate in the conduct of meetings, influencing them to participate in community activities, and helping to develop leadership skills (Flynn, Frick, \& Steele, 2010).

Boyd, Herring, and Briers (1992), in a study of 4-H club members aged 13 to 19 in Texas, showed that as the level of participation in 4-H increased, so did the level of leadership life skill development. These skills included working with groups, understanding oneself, communicating, making decisions, and leadership.

4-H campers between the ages of 8 and 21 were surveyed in West Virginia to measure their development of life and leadership skills as a result of their experiences during 4-H camp programs. Responsibility for one's own actions, respecting the rights and property of others, accepting differences, accepting responsibility for doing a job, and contributing as a member of a team were reported by older campers (ages 12-21) as the skills most learned in 4-H camp, while younger campers (ages 8-13) responded that they learned to accept differences, to respect the rights and property of others, to participate as a member of a team, and to listen carefully to what others say (Garton, Miltenberger, \& Pruett, 2007).

A study by Rusk, et al. (2003) found that 4-H members who participated in livestock projects developed not only skills related to caring for animals, but also valuable life skills. These include self-confidence, responsibility, decision-making, and people skills.

Walker (2003) studied the development of leadership and related life skills among youth who participated in beef cattle projects with the National Junior Angus 
Association. The findings indicated that leadership development was found among all participants, particularly in the areas of responsibility, goal-setting, and setting priorities.

In a study of Ohio swine project members’ life skill development by Shurson \& Lattner (1991) found that learning about sportsmanship and working with others, accepting responsibility, communicating with others, and decision-making were the primary life skills developed. Guthrie (1997) concluded that dairy cattle judging is important to provide individuals who will be entering the dairy industry with critical life skills, most notably communication skills, confidence, and decision-making skills.

A study by Everswick (2011) examined 4-H youth aged 13 through 19 in two New Jersey counties. The study found development in the areas of empathy, connections to others, competence in social, cognitive, and vocational skills, and character. A study on the impact of 4-H programs as reported by 4-H alumni in Nebraska, found that 4- $\mathrm{H}$ involvement positively affects the development of life skills. Among the life skills influenced by involvement were responsibility, the ability to handle competition, leadership, and self-confidence (Fox, et al., 2003).

Astroth (1996) determined that 4-H teaches skills that schools cannot by offering actual practice of those skills and allowing youth more autonomy over their decisions and learning. This leads to the development of leadership, decision-making, responsibility, and interpersonal skills.

Lerner and Lerner (2013) found that fifth-grade 4-H participants reported significantly higher levels of positive youth development (a term that covers competence, confidence, connection, character, and caring) than their non-4-H member peers who participated in other, unspecified extracurricular programs. 4-H youth were found to 
contribute more to their communities - helping others, providing service to their communities, and acting in leadership roles.

A survey of students in a college level horse judging course showed that students perceived themselves as developing a variety of life skills. These included decisionmaking, public speaking, self-evaluation, and teamsmanship skills (Potter \& Mulroy, 1994).

Radhakrishna, Everhart, \& Sinasky (2006) conducted a study of 4-H competitive event participants in Pennsylvania. Participant attitudes toward the competitive events revealed the perception that such events were beneficial to the development of life skills, self-esteem, and goal-setting.

A study of the alumni of 4-H animal science projects in New Jersey showed a positive relationship between participation on the projects and development in several life skills. Those skills included decision making, public speaking, self-esteem, and the ability to accept responsibility. Results for participation in shows and judging activities contributed the most to skill development (Ward, 1996).

4-H Youth Development programs in Maine were examined to determine their long-term impact on participants. Qualitative data in the form of narrative stories were collected from alumni and adult volunteers. Responses indicated that alumni perceived growth and development in skills such as accepting people who are different, community service, and making healthy choices, while adult volunteers saw youth develop skills in community service, record keeping, communication, and making decisions (Fitzpatrick et al., 2005). 
Involvement in 4-H horse projects in Nebraska was found by Anderson \& KarrLilienthal (2011) to positively influence the development of life skills such as handling pressure, sportsmanship, goal setting, self-motivation, and leadership. It was also indicated that project participants realized some relationship and benefit to their future college plans.

Armstrong (2010) studied the perceived life skill development of participants in the Florida 4-H program, comparing those with added experience in residential camping to those without. Those who camped showed greater development in life skills, especially in the areas of communication, leadership, and workforce preparation, as camping is promoted in Florida 4-H as a leadership opportunity.

Ladewig and Thomas (1987) reported that 4-H alumni rated highly the effects 4-H participation had on developing self-confidence, working with others, leadership skills, and the ability to communicate. Respondents also indicated that 4-H had an influence on preparing them for leadership and finishing their high school education.

Parents of 4-H youth involved in 4-H beef projects were studied in Texas to determine their perceptions of the life skill development their children showed as a result of participation in the 4-H beef project. The average age of the youths was 15 years of age, and accepting responsibility, setting goals, and self-discipline were the life skills in which their parents perceived the most development (Boleman, Cummings, \& Briers, 2004).

Research relating the development of life skills to career development, job performance, and the needs of employers is much less common than that focused on the development of life skills. Ward (1996) explored questions about the influence of 
participation in 4-H animal science programming on career choice and developing a career. Thirty-seven percent of respondents reported that participation in 4-H animal science programming influenced their career choice, and $46 \%$ reported that it assisted them in developing a career.

Nebraska 4-H alumni reported that their involvement in 4-H programs oriented toward career exploration and leadership development had an impact on their career development as adults. These programs taught them to make better use of time, how to work with people, and to conduct business meetings. (Rockwell, Stohler, \& Rudman, 1984).

Robinson (2006) assessed the employability skills of graduates of the College of Agriculture, Food, and Natural Resources at the University of Missouri-Columbia and looked at the importance of those skills in their fields of work. Those skills that were perceived to be most important for the workforce by graduates were solving problems, the ability to work independently, functioning well in stressful situations, maintaining a positive attitude, and listening attentively. Their immediate supervisors perceived the most important skills to be similar to the graduates, listing the most important skills as: working well with fellow employees, functioning well in stressful situations, the ability to work independently, solving problems, and maintaining a positive attitude. 


\section{CHAPTER III}

\section{Methodology}

\section{Purpose}

The purpose of this study was to determine how participation in West Virginia 4-H agricultural judging teams impacts life skills development. This study intends to determine the current life skill abilities of past 4-H state judging team winners from 1995 to 2006, determine how they perceive that ability was influenced by involvement on a judging team, and compare that with the importance of the various life skills in former participants' current jobs.

\section{Objectives}

The objectives of the study were:

1. To describe how participating as a part of a West Virginia 4-H state agricultural judging team impacts the development of life skills.

2. To describe how past West Virginia state 4-H judging team participants perceive their current level of life skill development.

3. To determine past West Virginia state 4-H judging teams members perceived importance of various life skills to their current job.

4. To describe how the life skills model used in 4-H programming relates to skills needed in employment situations. 


\section{Research Design}

A descriptive survey was utilized to collect data from the target population. This allows the collection of a wide scope of information, both qualitative and quantitative in nature. Descriptive research asks questions about the nature, incidence, or distribution of variables. Rather than manipulating variables, it involves only describing them (Ary, Jacobs, \& Razavieh, 2002). The design of this study was primarily quantitative, and also included several open-ended questions.

\section{Population}

The target population for this study was West Virginia state 4-H agricultural judging team contest winners from 1995 to 2006 who competed at the state level and went on to compete at the national level. A census was conducted of all these individuals. Members of teams who did not participate in a state level competition but were allowed to attend the national competition and who declined to participate in the national competition were excluded from the study. A list of past participants was provided by the State 4-H Youth Livestock specialist and a request was made to the county extension agents in the individuals home county at the time of participation to seek their assistance in providing current and up-to-date addresses for the individuals.

\section{Instrumentation}

The survey instrument was developed based on a review of literature. Content and face validity were established by a panel of experts consisting of West Virginia University faculty in Extension and Agricultural and Extension Education. Taking a 
census of the population controlled for sampling and selection errors. Institutional Review Board requirements at West Virginia University were met.

Internal reliability was determined by analyzing data from the population using the Spearman-Brown Coefficient. A rating of exemplary for internal reliability was found based on the analysis, which showed a Spearman-Brown Coefficient value of .894 (Robinson, Shaver, \& Wrightsman, 1991). Measurement errors were controlled by using a valid and reliable instrument.

The questionnaire sought to seek information related to the factors which influenced participation in judging teams, life skill development associated with involvement on judging teams and how beneficial those skills are in their current field of employment. The first group of questions pertained to influences that led subjects to join 4-H and 4-H judging teams, rating the influence various individuals had on participation. The rating scale used was: 1 - not at all influential, 2 - mildly influential, 3 - moderately influential, 4 - highly influential, and 5 - almost essential.

The second group of items dealt with participants’ experiences on 4-H judging teams. Respondents were given a series of diametrically opposed adjective pairs, such as "boring” and “exciting”, and asked to rate their experiences on a scale from 1 to 5 for each, with 1 being at the negative end of the scale.

The third set of items measured the influence participation on a judging team had on education and career choice. The rating scale for influence participation on a judging team had on education and career choice was: 1 - not at all influential, 2 - mildly influential, 3 - moderately influential, 4 - highly influential, and 5 - almost essential. 
The fourth section covered life skill development and current usage of life skills in respondents' jobs. Respondents were asked to rate their current level of ability in each of 35 life skills, as well as the level to which participation in a 4-H judging team contributed to the development of that ability and the importance of that life skill in their current jobs. The rating scale for current level of ability was: 1 - very poor, 2 - poor, 3 - average, 4 good, and 5 - excellent. The rating scale for judging team contribution to development and life skill importance in current job was: 1 - not at all influential, 2 - mildly influential, 3 - moderately influential, 4 - highly influential, and 5 - almost essential.

The list of 35 life skills was taken from the Targeting Life Skills Model by Hendricks (1996). Each skill listed was accompanied by a definition (see Figure 2).

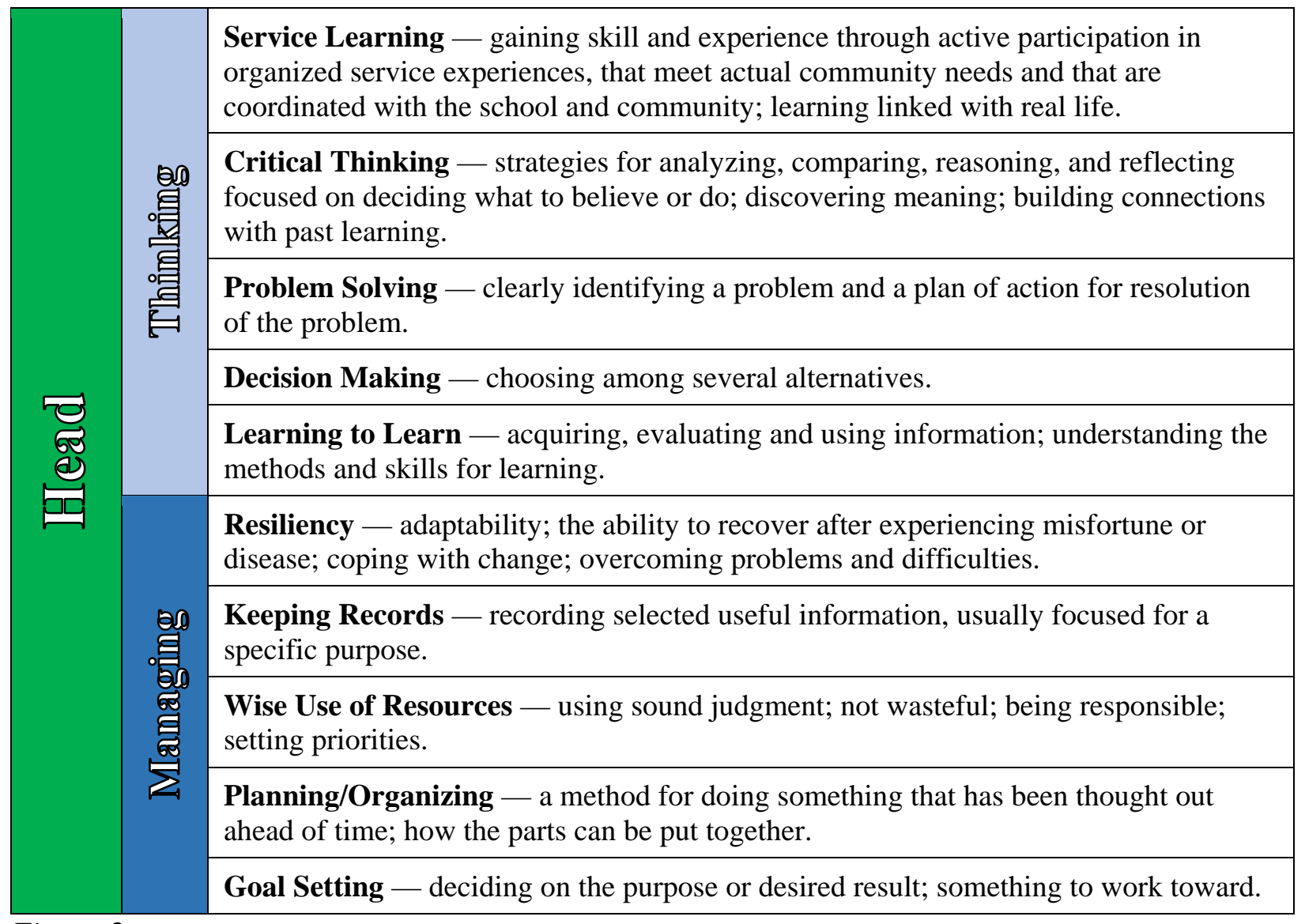

Figure 2

Definitions of Life Skills 


\begin{tabular}{|c|c|c|}
\hline & \multirow{4}{*}{ 富 } & $\begin{array}{l}\text { Nurturing Relationships - two or more people form a connection that contributes to } \\
\text { their mutual well being, each providing care and attention to the other person. }\end{array}$ \\
\hline & & Sharing — to have, use or do together with another or others. \\
\hline & & $\begin{array}{l}\text { Empathy — being sensitive to or identifying with another person's situation, feelings } \\
\text { or motives. }\end{array}$ \\
\hline & & Concern for others - to worry about, give attention to, the well being of others. \\
\hline & \multirow{5}{*}{ 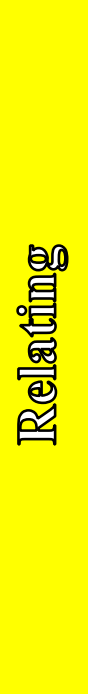 } & $\begin{array}{l}\text { Accepting Differences - to recognize and welcome factors that separate or } \\
\text { distinguish one person from another. }\end{array}$ \\
\hline & & $\begin{array}{l}\text { Conflict Resolution - finding and applying creative and non-destructive ways to } \\
\text { resolve differences between two or more persons; getting along with others. }\end{array}$ \\
\hline & & $\begin{array}{l}\text { Social Skills - skills people use when interacting with others and to behave in the } \\
\text { accepted manner or customs of the society in which they live; adapting well to one's } \\
\text { social environment. }\end{array}$ \\
\hline & & Cooperation — to work or act together for a common purpose or mutual benefit. \\
\hline & & $\begin{array}{l}\text { Communication - exchange of thoughts, information or messages between } \\
\text { individuals; sending and receiving information using speech, writing, gestures and } \\
\text { artistic expression. Public Speaking is not a life skill in the Hendricks model. For those } \\
\text { who want a definition Public Speaking — the ability to effectively communicate in } \\
\text { front of a group of people. }\end{array}$ \\
\hline \multirow{7}{*}{ 远 } & \multirow{4}{*}{ 造 } & $\begin{array}{l}\text { Community Service/Volunteering - to donate one's time and/or effort of one's own } \\
\text { free will for the benefit of the group without guarantee. }\end{array}$ \\
\hline & & $\begin{array}{l}\text { Leadership - to assist the group in meeting its goals by showing or directing along } \\
\text { the way; using personal influence to guide the group in reaching its goals. }\end{array}$ \\
\hline & & $\begin{array}{l}\text { Responsible Citizenship - an individual demonstrating love and devotion in } \\
\text { response to duties, rights, and privileges as a member of a community or country. }\end{array}$ \\
\hline & & $\begin{array}{l}\text { Contributions to group efforts — to give or supply along with others for a common } \\
\text { purpose. }\end{array}$ \\
\hline & \multirow{3}{*}{ 章 } & $\begin{array}{l}\text { Marketable Skills — to have the abilities wanted by employers and needed to hold a } \\
\text { job. }\end{array}$ \\
\hline & & Teamwork - work done by two or more people, each doing parts of the whole task. \\
\hline & & $\begin{array}{l}\text { Self-motivation — able to make the needed effort to carry out a task or a plan; } \\
\text { personal will to take action. }\end{array}$ \\
\hline
\end{tabular}

Figure 2 (continued)

Definitions of Life Skills 


\begin{tabular}{|c|c|c|}
\hline \multirow{9}{*}{ 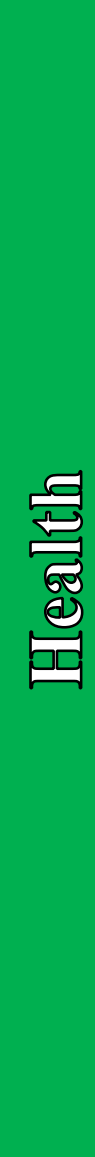 } & \multirow{5}{*}{ 嘼 } & $\begin{array}{l}\text { Self-esteem - pride in oneself; proper regard for oneself as a human being; valuing } \\
\text { oneself; a feeling of ability to cope; learning to accept and like oneself. }\end{array}$ \\
\hline & & $\begin{array}{l}\text { Self-responsibility — taking care of oneself; being accountable for one's behavior and } \\
\text { obligations; choosing for oneself between right and wrong. }\end{array}$ \\
\hline & & $\begin{array}{l}\text { Character - a person's moral strength; integrity, fortitude, reputation; a person's } \\
\text { usual qualities or traits; adherence to a code of values or ethical principles. }\end{array}$ \\
\hline & & $\begin{array}{l}\text { Managing Feelings - expressing one's feelings appropriately and in proportion to } \\
\text { circumstance. }\end{array}$ \\
\hline & & $\begin{array}{l}\text { Self-discipline - control of self and one's conduct in line with moral character (what } \\
\text { is right and wrong), personal values (what one considers important), and societal } \\
\text { expectations; control before acting in a hurtful or harmful way. }\end{array}$ \\
\hline & \multirow{4}{*}{ 量 } & $\begin{array}{l}\text { Healthy Lifestyle Choices - increased knowledge, attitudes and behaviors that } \\
\text { insure current good health, as well as those that assure future well-being such as: } \\
\text { exercise, nutrition, disease prevention, personal safety and stress management. }\end{array}$ \\
\hline & & $\begin{array}{l}\text { Stress Management - to direct or have control over physical or mental strain and } \\
\text { pressure, or one's reaction to it; coping with change. }\end{array}$ \\
\hline & & $\begin{array}{l}\text { Disease Prevention - to anticipate and ward off conditions that keep the body from } \\
\text { functioning normally, such as infection or stress that impairs normal physiological } \\
\text { functioning. }\end{array}$ \\
\hline & & $\begin{array}{l}\text { Personal Safety — taking care to avoid danger, risk, or harm; self-protection; being } \\
\text { cautious, careful; physically and emotionally safe. }\end{array}$ \\
\hline
\end{tabular}

Figure 2 (continued)

Definitions of Life Skills (Hendricks, 1996. Used by permission of Iowa State University Extension and Outreach.)

Lastly, the fifth set of items were demographic in nature. Information was requested on current age, level of education, current employment, and number of years as a participant in 4-H and on 4-H judging teams.

\section{Data Collection}

Recommendations from Dillman’s (2000) Tailored Design Method were used to design data collection methods. Packets were sent to each member of the target population via the United States Postal Service. Each packet contained a hand-signed 
cover letter explaining the purpose of the study, a copy of the questionnaire, a return envelope, and a slip for respondents to have their names entered into a drawing to receive a reward for participation. A number was placed on the corner of each return envelope to identify non-respondents. Two weeks after the initial mailing, non-respondents were identified and sent a second follow-up packet, again containing a cover letter, questionnaire, return envelope, and reward slip. A final postcard was sent as a reminder one week after the second mailing.

\section{Data Analysis}

Early and late respondents were compared to determine any differences between the two groups. No significant differences were found. Since no differences were found, it was assumed that early and late respondents were similar. Findings were therefore generalized to the entire target population.

\section{Use of Findings}

The study will provide information about the factors that lead to involvement in 4-H judging teams and the perceived benefits of participation. It will show a comparison between the life skill development of participants and the usage of those skills in their current jobs. The study results will provide Extension agents and specialist with information that will be valuable in conducting training for future judging teams. 


\section{CHAPTER IV}

\section{Findings}

\section{Purpose}

The purpose of this study was to determine how participation in West Virginia 4-H agricultural judging teams impacts life skills development. This study intends to determine the current life skill abilities of past 4-H state judging team winners from 1995 to 2006, determine how they perceive that ability was influenced by involvement on a judging team, and compare that with the importance of the various life skills in participants' current jobs.

\section{Objectives}

The objectives of the study were:

1. To describe how participating as a part of a West Virginia 4-H state agricultural judging team impacts the development of life skills.

2. To describe how past West Virginia state 4-H judging team participants perceive their current level of life skill development.

3. To determine past West Virginia state 4-H judging teams members perceived importance of various life skills to their current job.

4. To describe how the life skills model used in 4-H programming relates to skills needed in employment situations. 


\section{Analysis of Returned Surveys}

The target population for this study consisted of all West Virginia state 4-H agricultural judging team contest winners from 1995 to 2006. Of the original list of 320 winners, 33 were found to be undeliverable. A total of 117 surveys were returned from the remaining 287, one of which was unusable, for a total of 116 usable surveys. This translates to a response rate of $40.0 \%$.

Data were entered into an Excel spreadsheet and analyzed using the Statistical Package for the Social Sciences (SPSS). Descriptive analyses including frequencies, percentages, and means were used to evaluate numerical data, and responses to openended questions were recorded in full.

An independent $t$-test was used to compare the responses of early and late respondents to the number of years they participated in 4-H, their current age, and whether their current jobs were directly related to agriculture. No significant differences were found; generalizations were made to the target population.

\section{Demographics}

Respondents were asked to provide demographic information including number

of years as a member of $4-\mathrm{H}$, number of years as a participant on $4-\mathrm{H}$ judging teams, age, highest level of education, and current type of work.

Youth in West Virginia can be involved in 4-H between the ages of nine and 21 years. Respondents were asked to report the number of years they participated in 4-H. The mean number of years individuals indicated they had participated in 4-H was 10 years (see Table 1$)$. 
Table 1

Years of Participation in 4- $H$

\begin{tabular}{ccccc}
\hline & M & SD & Min & Max \\
\hline Years in 4-H & 9.99 & 3.03 & 1 & 18 \\
\hline
\end{tabular}

Years of participation on various judging teams varied at the different levels. At the local level, the mean number of years of participation on livestock judging teams was 5.3; for poultry judging it was 5.2 years; dairy cattle judging, 3.9 years; forestry judging, 1.4 years; horse judging, 3.2 years; land judging, 2.5 years; homesite evaluation, 2.8 years; and for horticulture judging, 3.6 years (see Table 2).

Table 2

Years on Local Judging Teams

\begin{tabular}{lcccc}
\hline & M & SD & Min & Max \\
\hline Livestock Judging & 5.33 & 3.00 & 1 & 12 \\
Poultry Judging & 5.21 & 2.92 & 1 & 12 \\
Dairy Cattle Judging & 3.91 & 3.21 & 1 & 10 \\
Forestry Judging & 1.40 & .70 & 1 & 3 \\
Horse Judging & 3.20 & 2.44 & 1 & 8 \\
Land Judging & 2.54 & 1.96 & 1 & 7 \\
Homesite Evaluation & 2.77 & 2.17 & 1 & 10 \\
\hline Horticulture Judging & 3.64 & 2.95 & 1 & 7 \\
\hline
\end{tabular}


At the state level, the mean number of years of participation on livestock judging teams was 5.0. For poultry judging the mean number of years was 5.2; dairy cattle judging, 3.1 years; forestry judging, 1.3 years; horse judging, 2.7 years; land judging, 2.5 years; homesite evaluation, 2.1 years; and horticulture judging, 4.0 years (see Table 3).

Table 3

Years on State Judging Teams

\begin{tabular}{lcccc}
\hline & M & SD & Min & Max \\
\hline Livestock Judging & 4.95 & 3.00 & 1 & 13 \\
Poultry Judging & 5.23 & 3.40 & 1 & 13 \\
Dairy Cattle Judging & 3.13 & 2.78 & 1 & 10 \\
Forestry Judging & 1.27 & .47 & 1 & 2 \\
Horse Judging & 2.71 & 2.52 & 1 & 8 \\
Land Judging & 2.47 & 1.89 & 1 & 7 \\
Homesite Evaluation & 2.11 & 1.66 & 1 & 10 \\
Horticulture Judging & 4.00 & 2.62 & 1 & \\
\hline
\end{tabular}

At the national level, the mean number of years of participation on livestock, poultry, land judging, and homesite evaluation teams was 1.0. For dairy cattle, forestry, and horse judging the mean was 1.1 years. For horticulture judging, the mean was 1.3 years of participation (see Table 4). 
Table 4

Years on National Judging Teams

\begin{tabular}{lcccc}
\hline & M & SD & Min & Max \\
\hline Livestock Judging & 1.00 & .00 & 1 & 1 \\
Poultry Judging & 1.04 & .21 & 1 & 2 \\
Dairy Cattle Judging & 1.07 & .26 & 1 & 2 \\
Forestry Judging & 1.10 & .32 & 1 & 2 \\
Horse Judging & 1.08 & .29 & 1 & 2 \\
Land Judging & 1.03 & .19 & 1 & 1 \\
Homesite Evaluation & 1.00 & .00 & 1 & 2 \\
Horticulture Judging & 1.30 & .48 & 1 & \\
\hline
\end{tabular}

A majority of respondents ( $\mathrm{N}=55,48.3 \%)$ were between the ages of 26 and 30 (see Table 5). Those ranging in age from 31 to 35 were the next most common, comprising 33.3\% of the population $(\mathrm{N}=38)$, followed by those aged 21 to $25(\mathrm{~N}=17$, $14.9 \%)$ and 36 to $40(\mathrm{~N}=4,3.5 \%)$. 
Table 5

Age of Respondents

\begin{tabular}{lcc}
\hline & $\mathrm{N}$ & $\%$ \\
\hline $21-25$ & 17 & 14.91 \\
$26-30$ & 55 & 48.25 \\
$31-35$ & 38 & 33.33 \\
$36-40$ & 4 & 3.51 \\
\hline
\end{tabular}

Most respondents indicated having either a Bachelor's or Master's degree, with 35.1\% ( $\mathrm{N}=40)$ having a Bachelor's and 26.3\% $(\mathrm{N}=30)$ a Master's (see Table 6). A number of courses of study among respondents were indicated, with business and related degrees $(\mathrm{N}=8)$, agriculture $(\mathrm{N}=7)$, animal science $(\mathrm{N}=7)$, and veterinary degrees $(\mathrm{N}=$ 5) being the most popular (see Appendix G). 
Table 6

Highest Level of Education

\begin{tabular}{lcc}
\hline & $\mathrm{N}$ & $\%$ \\
\hline Some High School & 0 & .00 \\
High School/GED & 7 & 6.14 \\
Technical School & 4 & 3.51 \\
Some College & 13 & 11.40 \\
Associate’s Degree & 6 & 5.26 \\
Bachelor's Degree & 40 & 35.09 \\
Master's Degree & 30 & 26.32 \\
Doctorate & 4 & 3.51 \\
Other Professional Degree & 10 & 8.77 \\
\hline
\end{tabular}

The jobs respondents currently held were of a varied nature. See Appendix G for a full listing of responses. More than half $(\mathrm{N}=74,66.1 \%)$ were reported to be not directly related to agriculture, with 38 respondents (33.9\%) indicating that their current job was directly related to agriculture. A majority $(\mathrm{N}=64,57.7 \%)$ of the respondents wanted to spend the remainder of their career in their current positions, while 47 respondents (42.3\%) did not (see Table 7). 
Table 7

Jobs Related to Agriculture and Desire to Remain in Current Career

\begin{tabular}{lcccc}
\hline & \multicolumn{3}{c}{ No } & \multicolumn{2}{c}{ Yes } \\
\cline { 2 - 5 } & $\mathrm{N}$ & $\%$ & $\mathrm{~N}$ & $\%$ \\
\hline Ag related & 74 & 66.07 & 38 & 33.93 \\
Rest of career & 47 & 42.34 & 64 & 57.66 \\
\hline
\end{tabular}

\section{Judging Team Practices and Experiences}

Respondents indicated the level of influence various persons had on their joining both 4-H and 4-H judging teams. Four respondents (3.5\%) answered that their parents were not at all influential to joining 4-H. Eight individuals (7.0\%) said parents were mildly influential, 17 (14.9\%) of those surveyed said that they were moderately influential, 41 (36.0\%)respondents replied that parents were highly influential, and 44 (38.6\%) people indicated that parents were almost essential.

When asked about the level of influence from other 4-H members, seven respondents (6.3\%) indicated that they were not at all influential, 13 of those surveyed (11.6\%) said they were mildly influential, 26 people (23.2\%) responded that they were moderately influential, 51 persons (45.5\%) said they were highly influential, and 15 individuals (13.4\%) reported that other 4-H members were almost essential.

When asked about how influential 4-H leaders were in their decision to join 4-H, 19 respondents each (17.1\%) indicated that they were not at all and mildly influential, 28 people (25.2\%) responded that they were moderately influential, 32 persons (28.8\%) said 
they were highly influential, and 13 of those surveyed (11.7\%) reported that $4-\mathrm{H}$ leaders were almost essential.

When asked how much influence teachers had on their decision to join 4-H, 61 individuals (58.1\%) indicated that they were not at all influential, 21 of those surveyed (20.0\%) said they were mildly influential, six persons (5.7\%) responded that they were moderately influential, seven respondents (6.8\%) said teachers were highly influential, and 10 individuals (9.5\%) reported that they were almost essential.

When asked how much influence brothers or sisters had on their decision to join 4-H, 45 people (42.1\%) said they were not at all influential, seven of those surveyed (6.5\%) said they were mildly influential, 14 respondents (13.1\%) responded that brothers or sisters were moderately influential, 20 persons (18.7\%) indicated they were highly influential, and 21 of those surveyed (19.6\%) responded that they were almost essential.

When asked how much extension agents influenced their decision to join 4-H, 29 of those surveyed (26.4\%) indicated that they were not at all influential, 17 persons (15.5\%) responded they were mildly influential, 20 individuals (18.2\%) indicated that they were moderately influential, 24 people (21.8\%) said they were highly influential, and 15 individuals (13.4\%) reported that extension agents were almost essential to their joining 4-H.

When asked how much other individuals influenced their decision to join 4-H, nine respondents replied that they were not at all influential, none of those surveyed indicated that they were either mildly or moderately influential, one person said they were highly influential, and two responded that other individuals were almost essential 
(see Table 8). See Appendix G for a list of the other individuals cited as influencing the decision to join 4-H.

Table 8

Influence on Joining 4-H

\begin{tabular}{|c|c|c|c|c|c|c|c|c|c|c|}
\hline & \multicolumn{2}{|c|}{$\begin{array}{l}\text { Not at all } \\
\text { influential }\end{array}$} & \multicolumn{2}{|c|}{$\begin{array}{c}\text { Mildly } \\
\text { influential }\end{array}$} & \multicolumn{2}{|c|}{$\begin{array}{l}\text { Moderately } \\
\text { influential }\end{array}$} & \multicolumn{2}{|c|}{$\begin{array}{c}\text { Highly } \\
\text { influential }\end{array}$} & \multicolumn{2}{|c|}{$\begin{array}{l}\text { Almost } \\
\text { essential }\end{array}$} \\
\hline & $\mathrm{N}$ & $\%$ & $\mathrm{~N}$ & $\%$ & $\mathrm{~N}$ & $\%$ & $\mathrm{~N}$ & $\%$ & $\mathrm{~N}$ & $\%$ \\
\hline Parents & 4 & 3.51 & 8 & 7.02 & 17 & 14.91 & 41 & 35.96 & 44 & 38.60 \\
\hline $\begin{array}{l}\text { Other 4-H } \\
\text { members }\end{array}$ & 7 & 6.25 & 13 & 11.61 & 26 & 23.21 & 51 & 45.54 & 15 & 13.39 \\
\hline 4-H leader & 19 & 17.12 & 19 & 17.12 & 28 & 25.23 & 32 & 28.83 & 13 & 11.71 \\
\hline Teacher & 61 & 58.10 & 21 & 20.00 & 6 & 5.71 & 7 & 6.67 & 10 & 9.52 \\
\hline $\begin{array}{l}\text { Brother/ } \\
\text { sister }\end{array}$ & 45 & 42.06 & 7 & 6.54 & 14 & 13.08 & 20 & 18.69 & 21 & 19.63 \\
\hline $\begin{array}{l}\text { Extension } \\
\text { agent }\end{array}$ & 29 & 26.36 & 17 & 15.45 & 20 & 18.18 & 24 & 21.82 & 20 & 18.18 \\
\hline Other & 9 & 75.00 & 0 & .00 & 0 & .00 & 1 & 8.33 & 2 & 16.67 \\
\hline
\end{tabular}

Those surveyed also indicated the influence individuals had on their joining 4- $\mathrm{H}$ judging teams. For parents, eight people (7.3\%) answered that they were not at all influential, 13 of those surveyed (11.8\%) responded that parents were mildly influential, 26 respondents (23.6\%) said that parents were moderately influential, 37 persons (33.6\%) reported parents were highly influential, and 26 individuals (23.6\%) reported that parents were almost essential to their decision to join a 4-H judging team. 
When asked about other 4-H members, eight of those surveyed (7.4\%) said that they were not at all influential, 11 people (10.2\%) said they were mildly influential, 25 individuals (23.2\%) responded that they were moderately influential, 44 people $(40.7 \%)$ indicated they were highly influential, and 20 persons (18.5\%) responded that other 4-H members were almost essential to their decision to join a 4-H judging team.

When asked about 4-H leaders, 14 people (13.2\%) indicated that they were not at all influential, 13 respondents (12.3\%) said they were mildly influential to their decision to join a 4-H judging team, 23 people (21.7\%) responded that 4-H leaders were moderately influential, 31 of those surveyed (29.3\%) said they were highly influential, and 25 individuals (23.6\%) reported that they were almost essential.

When asked about teachers, 57 persons (54.8\%) responded that they were not at all influential to the decision to join a 4-H judging team, 10 of those surveyed (9.6\%) reported they were mildly influential, 11 people (10.6\%) said they were moderately influential, and 13 individuals each (12.5\%) said they were highly influential and almost essential.

When asked about brothers or sisters, 50 respondents (48.1\%) said that they were not at all influential, nine of those surveyed (8.7\%) said they were mildly influential, 10 people (9.6\%) indicated that brothers or sisters were moderately influential, 13 of those surveyed (12.5\%) responded that they were highly influential, and 22 respondents (21.2\%) reported they were almost essential to their decision to join a 4-H judging team. When asked about extension agents, 18 respondents (16.7\%) indicated they were not at all influential, six of those surveyed (5.6\%) said they were mildly influential to their decision to join a 4-H judging team, 16 persons (14.8\%) responded that they were 
moderately influential, 29 people (26.9\%) said they were highly influential, and 39 respondents (36.1\%) reported that extension agents were almost essential.

When asked about other individuals, eight (61.5\%) people responded that they were not at all influential, none (0.0\%) said they were either mildly or moderately influential, one (7.7\%) respondent indicated they were highly influential to their decision to join a $4-\mathrm{H}$ judging team, and four (30.8\%) of those surveyed said that they were almost essential (see Table 9). For a full list of the other individuals mentioned as influencing their decision to join a judging team, please see Appendix G.

Table 9

Influence on Joining 4-H Judging Teams

\begin{tabular}{|c|c|c|c|c|c|c|c|c|c|c|}
\hline & \multicolumn{2}{|c|}{$\begin{array}{l}\text { Not at all } \\
\text { influential }\end{array}$} & \multicolumn{2}{|c|}{$\begin{array}{c}\text { Mildly } \\
\text { influential }\end{array}$} & \multicolumn{2}{|c|}{$\begin{array}{c}\text { Moderately } \\
\text { influential }\end{array}$} & \multicolumn{2}{|c|}{$\begin{array}{c}\text { Highly } \\
\text { influential }\end{array}$} & \multicolumn{2}{|c|}{$\begin{array}{c}\text { Almost } \\
\text { essential }\end{array}$} \\
\hline & $\mathrm{N}$ & $\%$ & $\mathrm{~N}$ & $\%$ & $\mathrm{~N}$ & $\%$ & $\mathrm{~N}$ & $\%$ & $\mathrm{~N}$ & $\%$ \\
\hline Parents & 8 & 7.27 & 13 & 11.82 & 26 & 23.64 & 37 & 33.64 & 26 & 23.64 \\
\hline $\begin{array}{l}\text { Other } 4-\mathrm{H} \\
\text { members }\end{array}$ & 8 & 7.41 & 11 & 10.19 & 25 & 23.15 & 44 & 40.74 & 20 & 18.52 \\
\hline 4-H leader & 14 & 13.21 & 13 & 12.26 & 23 & 21.70 & 31 & 29.25 & 25 & 23.58 \\
\hline Teacher & 57 & 54.81 & 10 & 9.62 & 11 & 10.58 & 13 & 12.50 & 13 & 12.50 \\
\hline $\begin{array}{l}\text { Brother/ } \\
\text { sister }\end{array}$ & 50 & 48.08 & 9 & 8.65 & 10 & 9.62 & 13 & 12.50 & 22 & 21.15 \\
\hline $\begin{array}{l}\text { Extension } \\
\text { agent }\end{array}$ & 18 & 16.67 & 6 & 5.56 & 16 & 14.81 & 29 & 26.85 & 39 & 36.11 \\
\hline Other & 8 & 61.54 & 0 & .00 & 0 & .00 & 1 & 7.69 & 4 & 30.77 \\
\hline
\end{tabular}


When asked which person or persons taught them the skills needed for 4-H judging, respondents credited extension agents most often $(\mathrm{N}=72,62.1 \%)$. Parents or guardians were indicated by 63 respondents (54.3\%), and other 4-H members by 61 individuals (52.6\%). 4-H leaders were selected by 40 survey participants (34.5\%), brothers/sisters by 33 respondents (28.5\%), teachers by 29 people (25.0\%), and only 27 respondents (23.3\%) selected the "other” category (see Table 10). See Appendix G for a full list of all individuals indicated for the "other" category of having taught skills needed for 4-H judging.

Table 10

Individuals Who Taught Respondents 4-H Judging Skills

\begin{tabular}{lcccc}
\hline & \multicolumn{2}{c}{ No } & \multicolumn{2}{c}{ Yes } \\
\cline { 2 - 5 } & $\mathrm{N}$ & $\%$ & $\mathrm{~N}$ & $\%$ \\
\hline Parents/guardians & 53 & 45.69 & 63 & 54.31 \\
Other 4-H members & 55 & 47.41 & 61 & 52.59 \\
4-H leader & 76 & 65.52 & 40 & 34.48 \\
Teacher & 87 & 75.00 & 29 & 25.00 \\
Brother/sister & 83 & 71.55 & 33 & 28.45 \\
Extension agent & 44 & 37.93 & 72 & 62.07 \\
Other & 89 & 76.72 & 27 & 23.28 \\
\hline
\end{tabular}

When asked to rate their judging team experiences on a continuum between “stressful” and “relaxing”, respondents were most likely to rate their experience as being slightly relaxing $(\mathrm{M}=3.2)$. When choosing between "terrifying” and "wonderful”, the 
average response placed the experience as being moderately wonderful $(\mathrm{M}=4.1)$. The choice between "boring” and “exciting” indicated that most found their participation to be exciting $(\mathrm{M}=4.5)$, and the choice between "waste of time" and "learning experience" showed that respondents were most likely to perceive $4-\mathrm{H}$ judging team involvement as a learning experience $(M=4.7)$ rather than a waste of time (see Table 11).

Table 11

Responses to Paired Adjectives

\begin{tabular}{lcccc}
\hline & M & SD & Min & Max \\
\hline Stressful-Relaxing & 3.24 & .90 & 2 & 5 \\
Terrifying-Wonderful & 4.13 & .90 & 1 & 5 \\
Boring-Exciting & 4.52 & .70 & 2 & 5 \\
$\begin{array}{l}\text { Waste of Time-Learning } \\
\text { Experience }\end{array}$ & 4.73 & .79 & 1 & 5 \\
\hline
\end{tabular}

Respondents were asked to indicate how often they practiced before both state and national judging contests. For the state contest, only eight people (7.3\%) practiced daily, while 33 of those surveyed (30.0\%) practiced once a week, 25 individuals $(22.7 \%)$ practiced twice a week, and 31 respondents (28.2\%) practiced more than twice a week. Seven respondents (6.4\%) practiced once every two weeks, and six individuals practiced (5.5\%) only once a month.

Before the national contest, 20 of those surveyed (18.7\%) practiced daily, 31 people (29.0\%) practiced more than twice a week, 24 respondents (22.4\%) practiced twice a week, and 18 individuals (16.8\%) practiced once a week. Seven respondents 
(6.5\%) each said that they practiced once every two weeks or once a month (see Table 12).

Table 12

Amount of Practice

\begin{tabular}{lcccc}
\hline & \multicolumn{2}{c}{ Before state contest } & \multicolumn{2}{c}{ Before national contest } \\
\cline { 2 - 5 } & $\mathrm{N}$ & $\%$ & $\mathrm{~N}$ & $\%$ \\
\hline Daily & 8 & 7.27 & 20 & 18.69 \\
More than twice a week & 31 & 28.18 & 31 & 28.97 \\
Twice a week & 25 & 22.73 & 24 & 22.43 \\
Once a week & 33 & 30.00 & 18 & 16.82 \\
Once every two weeks & 7 & 6.36 & 7 & 6.54 \\
Once a month & 6 & 5.45 & 7 & 6.54 \\
\hline
\end{tabular}

The majority of respondents $(\mathrm{N}=92,81.4 \%)$ indicated that there were no consequences if they missed judging practice prior to their state judging event (see Table 13). Among the consequences listed by those who answered to the affirmative were being kicked off the team and poor performance in the competition. See Appendix G for a full list of responses. 
Table 13

Consequences for Missed Practice

\begin{tabular}{llc}
\hline & $\mathrm{N}$ & $\%$ \\
\hline No & 92 & 81.42 \\
Yes & 21 & 18.58 \\
\hline
\end{tabular}

\section{Influence of Judging Team Participation on Education and Career Choice}

Respondents were asked about the influence of judging team participation on education and career choice. In regards to its effect on completing a high school education, 45 (39.5\%) of those surveyed said that judging team participation was not at all influential. Twenty people (17.5\%) said it was mildly influential, 21 individuals (18.4\%) said it was moderately influential, 13 of those surveyed (11.4\%) chose highly influential, eight people (7.0\%) said almost essential, and the remainder of the respondents $(\mathrm{N}=7,6.1 \%)$ said it was not applicable. With regard to continuing education beyond high school, 30 individuals (26.3\%) claimed that taking part in the 4-H judging team was not influential at all, 23 people (20.2\%) said it was mildly influential, 15 respondents (13.2\%) said moderately influential, 28 individuals (24.6\%) said highly influential, seven people (6.1\%) that it was almost essential, and 11 of those surveyed (9.7\%) chose not applicable.

When asked about their choice of college, 33 people (29.2\%) responded that judging team participation was not at all influential. Fifteen respondents (13.3\%) said it was mildly influential, 18 of those surveyed (15.9\%) said moderately influential, 25 individuals (22.1\%) said highly influential, 11 persons (9.7\%) said almost essential, and 
the remaining 11 (9.7\%) said not applicable. Choosing a college with a judging team was not at all influenced by judging team participation for 57 respondents (50.4\%). Eighteen of those surveyed (15.9\%) responded that their participation was mildly influential, six people (5.3\%) each said moderately and highly influential, seven individuals (6.2\%) said almost essential, and 19 persons (16.8\%) indicated that it was not applicable.

Finally, 34 individuals (30.1\%) responded that judging team participation was not at all influential on their choice of job or career. Sixteen people (14.2\%) said it was mildly influential, 22 individuals (19.5\%) said moderately influential, 21 of those surveyed (18.6\%) said highly influential, 11 respondents (9.7\%) said almost essential, and the remaining 9 (8.0\%) said not applicable (see Table 14). 
Table 14

Judging Team Influence on Education and Career Choice

\begin{tabular}{|c|c|c|c|c|c|c|c|c|c|c|c|c|}
\hline & \multicolumn{2}{|c|}{$\begin{array}{c}\text { Not at all } \\
\text { influential }\end{array}$} & \multicolumn{2}{|c|}{ Mildly influential } & \multicolumn{2}{|c|}{$\begin{array}{c}\text { Moderately } \\
\text { influential }\end{array}$} & \multicolumn{2}{|c|}{ Highly influential } & \multicolumn{2}{|c|}{ Almost essential } & \multicolumn{2}{|c|}{ Not applicable } \\
\hline & $\mathrm{N}$ & $\%$ & $\mathrm{~N}$ & $\%$ & $\mathrm{~N}$ & $\%$ & $\mathrm{~N}$ & $\%$ & $\mathrm{~N}$ & $\%$ & $\mathrm{~N}$ & $\%$ \\
\hline Completing HS & 45 & 39.47 & 20 & 17.54 & 21 & 18.42 & 13 & 11.40 & 8 & 7.02 & 7 & 6.14 \\
\hline $\begin{array}{l}\text { Continuing } \\
\text { beyond HS }\end{array}$ & 30 & 26.32 & 23 & 20.18 & 15 & 13.16 & 28 & 24.56 & 7 & 6.14 & 11 & 9.65 \\
\hline College choice & 33 & 29.20 & 15 & 13.27 & 18 & 15.93 & 25 & 22.12 & 11 & 9.73 & 11 & 9.73 \\
\hline $\begin{array}{l}\text { College w/judging } \\
\text { team }\end{array}$ & 57 & 50.44 & 18 & 15.93 & 6 & 5.31 & 6 & 5.31 & 7 & 6.19 & 19 & 16.81 \\
\hline Career/job choice & 34 & 30.09 & 16 & 14.16 & 22 & 19.47 & 21 & 18.58 & 11 & 9.73 & 9 & 7.96 \\
\hline
\end{tabular}




\section{Life Skills}

Respondents were asked to rate their current level of ability in a series of 35 life skills. These life skills and their definitions were taken from the Targeting Life Skills Model by Hendricks (1996), which groups each skill under a broad heading of one of the four H’s, hands, health, head, and heart. The model breaks the skills further into subheadings, placing giving and working under the broad heading of Hands, being and living under the heading of Health, thinking and managing under the heading of Head, and relating and caring under the heading of Heart.

\section{Hands}

\section{Giving}

When asked about their current levels of community service/volunteering, 36 respondents (31\%) rated their skill as excellent, 42 of those surveyed (36.2\%) rated their skill as good, 28 individuals (24.1\%) rated their skill as average, nine people (7.8\%) rated their skill as poor, and one person (0.9\%) rated their skill as very poor.

When asked about their current level of leadership ability, 43 respondents (37.1\%) rated their skill as excellent, 56 people (48.3\%) rated their skill as good, 14 individuals $(12.1 \%)$ rated their skill as average, and two persons (1.7\%) rated their skill as poor. One person (0.9\%) rated their skill as very poor.

With regard to their current level of skill in responsible citizenship, 45 respondents (38.8\%) rated their skill as excellent, 59 of those surveyed (50.9\%) rated their skill as good, 11 individuals (9.5\%) rated their skill as average, and one person (0.9\%) rated their skill as poor. When asked about their current level of skill with contributions to group effort, 47 respondents (40.5\%) rated their skill as excellent, 58 of 
those surveyed (50.0\%) rated their skill as good, 10 individuals (8.6\%) rated their skill as average, one person (0.9\%) rated their skill with contributions to group effort as poor, and none rated their skill as very poor.

\section{Working}

In regard to their current level of ability with marketable skills, 60 respondents (51.7\%) rated their skill as excellent, 49 of those surveyed (42.2\%) rated their skill as good, six individuals (5.2\%) rated their skill as average, one person (0.9\%) rated their skill as poor, and none rated their skill as very poor. When questioned about their current skills with teamwork, 56 respondents (48.3\%) rated their skill as excellent, 53 of those surveyed (45.7\%) rated their skill as good, five individuals (4.3\%) rated their skill as average, two people (1.7\%) rated their skill as poor, and zero rated their skill as very poor.

In response to questioning about their current level of self-motivation, 64 respondents (55.2\%) rated their skill as excellent, 46 of those surveyed (39.7\%) rated their skill as good, four individuals (3.5\%) rated their skill as average, and two respondents $(1.7 \%)$ rated their skill as poor. None rated their skill as very poor. Health

Being

When asked about their current level of self-esteem, 45 respondents (38.8\%) rated their skill as excellent, 51 of those surveyed (44.0\%) rated their skill as good, 16 individuals (13.8\%) rated their skill as average, three people (2.6\%) rated their skill as poor, and one person (0.9\%) rated their skill as very poor. 
In regard to their current level of self-responsibility, 72 respondents (62.1\%) rated their skill as excellent, 40 of those surveyed (34.5\%) rated their skill as good, four individuals (3.5\%) rated their skill as average, and none rated their skill as either poor or very poor. With regard to character, 64 respondents (55.2\%) rated their skill as excellent, 47 of those surveyed (40.5\%) rated their skill as good, four individuals (3.5\%) rated their skill as average, one person (0.9\%) rated their skill as poor, and not a soul rated their skill as very poor.

When asked about their current level of skill in managing feelings, 28 respondents (24.1\%) rated their skill as excellent, 65 of those surveyed (56.0\%) rated their skill as good, 19 individuals (16.4\%) rated their skill as average, four people (3.5\%) rated their skill as poor, and none rated their skill in managing feelings as very poor. When questioned in regard to their current levels of self-discipline, 53 respondents (45.7\%) rated their skill as excellent, 54 of those surveyed (46.6\%) rated their skill as good, eight individuals (6.9\%) rated their skill as average, one person (0.9\%) rated their skill as poor, and none rated their skill as very poor.

\section{Living}

When reporting their current skill in making healthy lifestyle choices, 24 respondents (20.7\%) rated their skill as excellent, 56 of those surveyed (48.3\%) rated their skill as good, 34 individuals (29.3\%) rated their skill in making healthy lifestyle choices as average, two people (1.7\%) rated their skill as poor, and none rated their skill as very poor. When asked to rate their current abilities in stress management, 14 respondents (12.1\%) rated their skill as excellent, 58 of those surveyed (50.0\%) rated 
their skill as good, 39 individuals (33.6\%) rated their skill as average, four people (3.5\%) rated their skill as poor, and one person (0.9\%) rated their skill as very poor.

In regard to their current skills in disease prevention, 29 people (25.0\%) rated their skill as excellent, 61 individuals (52.6\%) rated their skill as good, 26 of those surveyed (22.4\%) rated their skill as average, and no respondents rated their skill as poor or very poor. When asked about their current level of skill in personal safety, 35 people (30.2\%) rated their skill as excellent, 62 individuals (53.5\%) rated their skill as good, 18 of those surveyed (22.4\%) rated their skill as average, one respondent (0.9\%) rated their skill as poor, and none rated their skill as very poor.

Head

\section{Thinking}

When questioned about their current abilities in learning to learn, 52 people (44.8\%) rated their skill as excellent, 57 individuals (49.1\%) rated their skill as good, seven of those surveyed (6.0\%) rated their skill as average, and no respondents rated their skill as poor or very poor. With regard to their current ability in decision making, 50 people (43.1\%) rated their skill as excellent, 52 individuals (44.8\%) rated their skill as good, 13 of those surveyed (11.2\%) rated their skill as average, one respondent ( $0.9 \%)$ rated their skill as poor, and none rated their skill in decision making as very poor.

When asked to rate their current skill level in problem solving, 57 people (49.6\%) rated their skill as excellent, 44 individuals (38.3\%) rated their skill as good, 14 of those surveyed (12.2\%) rated their skill in problem solving as average, and no respondents rated their skill as poor or very poor. When asked about their current level of ability in critical thinking, 57 respondents (49.1\%) indicated that their skill was excellent, 42 of 
those surveyed (36.2\%) rated their skill as good, 16 people (13.8\%) rated their skill as average, one person ( $0.9 \%)$ rated their skill as poor, and none rated their skill as very poor.

In regard to their current skill abilities in service learning, 33 respondents (28.5\%) indicated that their skill was excellent, 55 of those surveyed (47.4\%) rated their skill as good, 24 people (20.7\%) rated their skill as average, and four people (3.5\%) rated their skill as poor. None rated their skill as very poor.

\section{Managing}

When asked to indicate their current abilities in goal setting, 38 respondents (32.8\%) indicated that their skill was excellent, 57 of those surveyed (49.1\%) rated their skill as good, 20 people (17.2\%) rated their skill as average, one person $(0.9 \%)$ rated their skill as poor, and none rated their skill as very poor.

When asked to rank their current skills in planning/organizing, 42 respondents (36.2\%) indicated that their skill was excellent, 55 of those surveyed (47.4\%) rated their skill as good, 16 people (13.8\%) rated their skills in planning/organizing as average, three individuals (2.6\%) rated their skill as poor, and none rated their skill as very poor. With regard to their current skill in the wise use of resources, 39 respondents (33.9\%) indicated that their skill was excellent, 66 of those surveyed (57.4\%) rated their skill as good, 10 people (8.7\%) rated their skill as average, and none rated their skill in the wise use of resources as poor or very poor.

When questioned about their current level of ability in keeping records, 34 respondents (29.6\%) indicated that their skill was excellent, 58 of those surveyed (50.4\%) rated their skill as good, 20 people (17.4\%) rated their skill as average, three individuals 
(2.6\%) rated their skill as poor, and none rated their skill as very poor. When asked about their current levels of resiliency, 37 individuals (32.2\%) rated their skill as excellent, 49 people (42.6\%) rated their skill as good, 27 of those surveyed (23.5\%) rated their skill as average, two respondents (1.7\%) rated their skill as poor, and none rated their skill as very poor.

Heart

\section{Relating}

In regard to questioning about their current level of communication skills, 33 individuals (32.2\%) rated their skill as excellent, 63 people (42.6\%) rated their skill as good, 17 of those surveyed (23.5\%) rated their skill as average, one respondent $(0.9 \%)$ rated their skill as poor, and one person $(0.9 \%)$ rated their communication skills as very poor. With regard to their current skills with cooperation, 48 individuals (41.7\%) rated their skill as excellent, 52 people (45.2\%) rated their skill as good, 14 of those surveyed (12.2\%) rated their skill as average, one respondent $(0.9 \%)$ rated their skill as poor, and none rated their skill as very poor.

When asked about their current social skills, 43 individuals (37.4\%) rated their skill as excellent, 54 people (47.0\%) rated their skill as good, 15 of those surveyed (13.0\%) rated their skill as average, three respondents (2.6\%) rated their skill as poor, and none rated their skill as very poor. When questioned on their current skill in conflict resolution, 22 individuals (19.1\%) rated their skill as excellent, 65 people (56.5\%) rated their skill as good, 25 of those surveyed (21.7\%) rated their skill as average, three respondents $(2.6 \%)$ rated their skill as poor, and none rated their skill as very poor. 
In response to questioning about their current ability in accepting differences, 40 individuals (34.8\%) rated their skill as excellent, 49 people (42.6\%) rated their skill as good, 25 of those surveyed (21.7\%) rated their skill as average, and one respondent (0.9\%) rated their skill as poor. None rated their skill as very poor.

\section{Caring}

In regard to their current levels of concern for others, 52 individuals (45.2\%) rated their skill as excellent, 44 of those surveyed (38.3\%) rated their skill as good, 18 people (15.7\%) rated their skill as average, and one respondent (.9\%) rated their skill as poor. None rated their skill as very poor.

When asked to indicate their current level of ability in empathy, 38 individuals (33.0\%) rated their skill as excellent, 44 people (38.3\%) rated their skill as good, 21 of those surveyed (18.3\%) rated their skill as average, three respondents (2.6\%) rated their skill as poor, and none rated their skill as very poor. With regard to their current level of skill in sharing, 37 individuals (32.2\%) rated their skill as excellent, 56 people (48.7\%) rated their skill in sharing as good, 20 of those surveyed (17.4\%) rated their skill as average, two respondents (1.7\%) rated their skill as poor, and none rated their skill as very poor.

Lastly, when asked about their current ability in nurturing relationships, 37 individuals (32.2\%) rated their skill as excellent, 58 people (50.4\%) rated their skill as good, and 20 of those surveyed (17.4\%) rated their skill as average. None rated their skill as poor or very poor (see Table 15). 
Table 15

Current Skill Levels

\begin{tabular}{|c|c|c|c|c|c|c|c|c|c|c|}
\hline & \multicolumn{2}{|c|}{ Very Poor } & \multicolumn{2}{|c|}{ Poor } & \multicolumn{2}{|c|}{ Average } & \multicolumn{2}{|c|}{ Good } & \multicolumn{2}{|c|}{ Excellent } \\
\hline & $\mathrm{N}$ & $\%$ & $\mathrm{~N}$ & $\%$ & $\mathrm{~N}$ & $\%$ & $\mathrm{~N}$ & $\%$ & $\mathrm{~N}$ & $\%$ \\
\hline \multicolumn{11}{|l|}{ Community } \\
\hline \multicolumn{11}{|l|}{ Service/ } \\
\hline Volunteering & 1 & .86 & 9 & 7.76 & 28 & 24.14 & 42 & 36.21 & 36 & 31.03 \\
\hline Leadership & 1 & .86 & 2 & 1.72 & 14 & 12.07 & 56 & 48.28 & 43 & 37.07 \\
\hline \multicolumn{11}{|l|}{ Responsible } \\
\hline Citizenship & 0 & .00 & 1 & .86 & 11 & 9.48 & 59 & 50.86 & 45 & 38.79 \\
\hline \multicolumn{11}{|l|}{ Contributions } \\
\hline to Group Effort & 0 & .00 & 1 & .86 & 10 & 8.62 & 58 & 50.00 & 47 & 40.52 \\
\hline \multicolumn{11}{|l|}{ Marketable } \\
\hline Skills & 0 & .00 & 1 & .86 & 6 & 5.17 & 49 & 42.24 & 60 & 51.72 \\
\hline Teamwork & 0 & .00 & 2 & 1.72 & 5 & 4.31 & 53 & 45.69 & 56 & 48.28 \\
\hline Self-Motivation & 0 & .00 & 2 & 1.72 & 4 & 3.45 & 46 & 39.66 & 64 & 55.17 \\
\hline Self-Esteem & 1 & .86 & 3 & 2.59 & 16 & 13.79 & 51 & 43.97 & 45 & 38.79 \\
\hline \multicolumn{11}{|l|}{ Self- } \\
\hline Responsibility & 0 & .00 & 0 & .00 & 4 & 3.45 & 40 & 34.48 & 72 & 62.07 \\
\hline Character & 0 & .00 & 1 & .86 & 4 & 3.45 & 47 & 40.52 & 64 & 55.17 \\
\hline \multicolumn{11}{|l|}{ Managing } \\
\hline Feelings & 0 & .00 & 4 & 3.45 & 19 & 16.38 & 65 & 56.03 & 28 & 24.14 \\
\hline Self-Discipline & 0 & .00 & 1 & .86 & 8 & 6.90 & 54 & 46.55 & 53 & 45.69 \\
\hline \multicolumn{11}{|l|}{ Healthy } \\
\hline \multicolumn{11}{|l|}{ Lifestyle } \\
\hline Choices & 0 & .00 & 2 & 1.72 & 34 & 29.31 & 56 & 48.28 & 24 & 20.69 \\
\hline
\end{tabular}


Table 15 (continued)

Current Skill Levels

\begin{tabular}{|c|c|c|c|c|c|c|c|c|c|c|}
\hline & \multicolumn{2}{|c|}{ Very Poor } & \multicolumn{2}{|c|}{ Poor } & \multicolumn{2}{|c|}{ Average } & \multicolumn{2}{|c|}{ Good } & \multicolumn{2}{|c|}{ Excellent } \\
\hline & $\mathrm{N}$ & $\%$ & $\mathrm{~N}$ & $\%$ & $\mathrm{~N}$ & $\%$ & $\mathrm{~N}$ & $\%$ & $\mathrm{~N}$ & $\%$ \\
\hline \multicolumn{11}{|l|}{ Stress } \\
\hline Management & 1 & .86 & 4 & 3.45 & 39 & 33.62 & 58 & 50.00 & 14 & 12.07 \\
\hline \multicolumn{11}{|l|}{ Disease } \\
\hline Prevention & 0 & .00 & 0 & .00 & 26 & 22.41 & 61 & 52.59 & 29 & 25.00 \\
\hline Personal Safety & 0 & .00 & 1 & .86 & 18 & 15.52 & 62 & 53.45 & 35 & 30.17 \\
\hline \multicolumn{11}{|l|}{ Learning to } \\
\hline Learn & 0 & .00 & 0 & .00 & 7 & 6.03 & 57 & 49.14 & 52 & 44.83 \\
\hline \multicolumn{11}{|l|}{ Decision } \\
\hline Making & 0 & .00 & 1 & .86 & 13 & 11.21 & 52 & 44.83 & 50 & 43.10 \\
\hline \multicolumn{11}{|l|}{ Problem } \\
\hline Solving & 0 & .00 & 0 & .00 & 14 & 12.17 & 44 & 38.26 & 57 & 49.57 \\
\hline \multicolumn{11}{|l|}{ Critical } \\
\hline Thinking & 0 & .00 & 1 & .86 & 16 & 13.79 & 42 & 36.21 & 57 & 49.14 \\
\hline \multicolumn{11}{|l|}{ Service } \\
\hline Learning & 0 & .00 & 4 & 3.45 & 24 & 20.69 & 55 & 47.41 & 33 & 28.45 \\
\hline Goal Setting & 0 & .00 & 1 & .86 & 20 & 17.24 & 57 & 49.14 & 38 & 32.76 \\
\hline \multicolumn{11}{|l|}{ Planning/ } \\
\hline Organizing & 0 & .00 & 3 & 2.59 & 16 & 13.79 & 55 & 47.41 & 42 & 36.21 \\
\hline \multicolumn{11}{|l|}{ Wise Use of } \\
\hline Resources & 0 & .00 & 0 & .00 & 10 & 8.70 & 66 & 57.39 & 39 & 33.91 \\
\hline \multicolumn{11}{|l|}{ Keeping } \\
\hline Records & 0 & .00 & 3 & 2.61 & 20 & 17.39 & 58 & 50.43 & 34 & 29.57 \\
\hline Resiliency & 0 & .00 & 2 & 1.74 & 27 & 23.48 & 49 & 42.61 & 37 & 32.17 \\
\hline
\end{tabular}


Table 15 (continued)

Current Skill Levels

\begin{tabular}{|c|c|c|c|c|c|c|c|c|c|c|}
\hline & \multicolumn{2}{|c|}{ Very Poor } & \multicolumn{2}{|c|}{ Poor } & \multicolumn{2}{|c|}{ Average } & \multicolumn{2}{|c|}{ Good } & \multicolumn{2}{|c|}{ Excellent } \\
\hline & $\mathrm{N}$ & $\%$ & $\mathrm{~N}$ & $\%$ & $\mathrm{~N}$ & $\%$ & $\mathrm{~N}$ & $\%$ & $\mathrm{~N}$ & $\%$ \\
\hline Communication & 1 & .87 & 1 & .87 & 17 & 14.78 & 63 & 54.78 & 33 & 28.70 \\
\hline Cooperation & 0 & .00 & 1 & .87 & 14 & 12.17 & 52 & 45.22 & 48 & 41.74 \\
\hline Social Skills & 0 & .00 & 3 & 2.61 & 15 & 13.04 & 54 & 46.96 & 43 & 37.39 \\
\hline \multicolumn{11}{|l|}{ Conflict } \\
\hline Resolution & 0 & .00 & 3 & 2.61 & 25 & 21.74 & 65 & 56.52 & 22 & 19.13 \\
\hline \multicolumn{11}{|l|}{ Accepting } \\
\hline Differences & 0 & .00 & 1 & .87 & 25 & 21.74 & 49 & 42.61 & 40 & 34.78 \\
\hline \multicolumn{11}{|l|}{ Concern for } \\
\hline Others & 0 & .00 & 1 & .87 & 18 & 15.65 & 44 & 38.26 & 52 & 45.22 \\
\hline Empathy & 0 & .00 & 3 & 2.61 & 21 & 18.26 & 53 & 46.09 & 38 & 33.04 \\
\hline Sharing & 0 & .00 & 2 & 1.74 & 20 & 17.39 & 56 & 48.70 & 37 & 32.17 \\
\hline \multicolumn{11}{|l|}{ Nurturing } \\
\hline Relationships & 0 & .00 & 0 & .00 & 20 & 17.39 & 58 & 50.43 & 37 & 32.17 \\
\hline
\end{tabular}

Those who participated in the study indicated the level to which participation on 4-H judging teams influenced their development of each life skill listed. Following is a description of their responses.

\section{Hands}

Giving

When asked about community service/volunteering, 13 individuals (11.3\%) responded that judging team participation was almost essential to their development, 48 
(41.7\%) respondents said that it was highly influential, 32 (27.8\%) of those surveyed indicated that it was moderately influential, 16 people said that it was mildly influential, and 6 (5.2\%) respondents answered that community service/volunteering was not at all influential. In regard to leadership, 27 respondents (23.3\%) said that judging team participation was almost essential in development of the skill, 54 people (46.6\%) said that it was highly influential, 25 individuals (21.6\%) said that it was moderately influential, nine people (7.8\%) indicated that it was mildly influential, and one person (0.9\%) responded that it was not at all influential.

When questioned about responsible citizenship, 23 respondents (19.8\%) said that judging team participation was almost essential in development of the skill, 43 people (37.1\%) said that it was highly influential, 38 individuals (32.8\%) said that responsible citizenship was moderately influential, 10 people (8.6\%) indicated that it was mildly influential, and two of those surveyed (1.7\%) responded that it was not at all influential. With regard to questioning about contributions to group effort, 48 respondents (41.4\%) said that judging team participation was almost essential in development of the skill, 44 people (37.9\%) said that it was highly influential, 19 individuals (16.4\%) said that it was moderately influential, three people (2.6\%) indicated that it was mildly influential, and two of those surveyed (1.7\%) responded that it was not at all influential.

\section{Working}

With regard to marketable skills, 19 respondents (16.5\%) said that judging team participation was almost essential in development of the skill, 56 people (48.7\%) said that marketable skills were highly influential, 29 individuals (25.2\%) said that they were moderately influential, 10 people ( $8.7 \%)$ indicated that they were mildly influential, and 
one person $(0.9 \% \%)$ responded that they were not at all influential. When asked about teamwork, 57 individuals (16.5\%) said that judging team participation was almost essential in development of the skill, 33 people (29.0\%) indicated that teamwork was highly influential, 21 of those surveyed (18.4\%) responded that it was moderately influential, two people (1.8\%) indicated that it was mildly influential, and one person (0.9\%) said that teamwork was not at all influential.

In regard to questioning about self-motivation, 42 individuals (36.2\%) said that judging team participation was almost essential in development of the skill, 43 people (37.1\%) indicated that it was highly influential, 22 of those surveyed (19.0\%) responded that it was moderately influential, and seven people (6.0\%) indicated that self-motivation was mildly influential. Only two respondents (1.7\%) said that it was not at all influential. Health

\section{Being}

When responding to questioning on self-esteem, 28 individuals (24.1\%) said that judging team participation was almost essential in their development, 54 people (46.6\%) indicated that it was highly influential, 26 of those surveyed (22.4\%) responded that it was moderately influential, and five people (4.3\%) indicated that it was mildly influential. The remaining three respondents (2.6\%) said that it was not at all influential.

With regard to self-responsibility, 38 individuals (32.8\%) said that judging team participation was almost essential in development of the skill, 45 people (38.8\%) indicated that self-responsibility was highly influential, 25 of those surveyed (21.6\%) responded that it was moderately influential, seven people (6.0\%) indicated that it was mildly influential, and one person (0.9\%) said that it was not at all influential. When 
asked about character, 39 people (33.9\%) indicated that judging team participation was almost essential in development, 40 people (34.8\%) said that it was highly influential, 24 of those surveyed (20.9\%) responded that it was moderately influential, 11 individuals (9.6\%) indicated that it was mildly influential, and one person (0.9\%) said that it was not at all influential.

With regard to questioning about managing feelings, 19 people (16.4\%) indicated that judging team participation was almost essential in development, 41 people (35.3\%) said that it was highly influential, 30 of those surveyed (25.9\%) responded that managing feelings was moderately influential, 21 individuals (18.1\%) indicated that it was mildly influential, and five persons (4.3\%) said that it was not at all influential. When questioned about self-discipline, 33 people (28.5\%) indicated that judging team participation was almost essential in development of the skill, 40 people (34.5\%) said that it was highly influential, 31 of those surveyed (26.7\%) responded that it was moderately influential, 10 individuals (8.6\%) indicated that it was mildly influential, and two people (1.7\%) said that it was not at all influential.

\section{Living}

When asked about healthy lifestyle choices, six respondents (5.2\%) indicated that judging team participation was almost essential in development, 21 people (18.3\%) said that it was highly influential, 41 of those surveyed (35.7\%) responded that healthy lifestyle choices was moderately influential, 24 individuals (20.9\%) indicated that it was mildly influential, and 23 people (20.0\%) said that it was not at all influential. In regard to stress management, 11 people (9.5\%) indicated that judging team participation was almost essential in development of the skill, 30 respondents (25.9\%) said that it was 
highly influential, 49 individuals (42.4\%) responded that it was moderately influential, 24 persons (20.7\%) indicated that it was mildly influential, and two of those surveyed (1.7\%) said that stress management was not at all influential.

With regard to disease prevention, nine people (7.8\%) indicated that judging team participation was almost essential in development, 14 respondents (12.2\%) said that it was highly influential, 33 individuals (28.7\%) responded that it was moderately influential, 34 persons (29.6\%) indicated that it was mildly influential, and 25 of those surveyed (21.7\%) said that it was not at all influential. In regard to questioning about personal safety, 12 people (10.3\%) indicated that judging team participation was almost essential in development, 30 respondents (25.9\%) said that it was highly influential, 33 individuals (28.5\%) responded that personal safety was moderately influential, 26 persons (22.4\%) indicated that it was mildly influential, and 15 of those surveyed (23.9\%) said that it was not at all influential.

Head

Thinking

When asked about learning to learn, 39 respondents (33.6\%) indicated that judging team participation was almost essential in development, 55 individuals (47.4\%) responded that it was highly influential, 17 respondents (14.7\%) said that it was moderately influential, four people (3.5\%) indicated that it was mildly influential, and one person (0.9\%) said that it was not at all influential. When questioned about decision making, 46 respondents (39.7\%) indicated that judging team participation was almost essential in development of the skill, 41 individuals (35.3\%) responded that it was highly influential, 23 respondents (19.8\%) said that decision making was moderately influential, 
five people (4.3\%) indicated that it was mildly influential, and one person $(0.9 \%)$ said that it was not at all influential.

In regard to problem solving, 35 respondents (30.2\%) indicated that judging team participation was almost essential in development of the skill, 43 individuals (37.1\%) responded that it was highly influential, 28 respondents (24.1\%) said that it was moderately influential, nine people (7.8\%) indicated that it was mildly influential, and one person (0.9\%) said that it was not at all influential. When asked about critical thinking, 40 respondents (34.5\%) indicated that judging team participation was almost essential in development of the skill, 43 individuals (37.1\%) responded that it was highly influential, 24 respondents (20.7\%) said that it was moderately influential, eight people (6.9\%) indicated that it was mildly influential, and one person (0.9\%) said that critical thinking was not at all influential.

With regard to service learning, 30 of those surveyed (25.9\%) responded that judging team participation was almost essential in development, 41 people (35.3\%) said that it was highly influential, 28 individuals (24.1\%) indicated that it was moderately influential, and 13 people (11.2\%) responded that it was mildly influential. The remaining four (3.5\%) said that it was not at all influential.

\section{Managing}

When questioned about goal setting, 30 of those surveyed (25.9\%) responded that judging team participation was almost essential in development, 45 people (38.8\%) said that goal setting was highly influential, 31 individuals (26.7\%) indicated that it was moderately influential, and nine people (7.8\%) responded that it was mildly influential. One person (0.9\%) said that it was not at all influential. 
In response to questioning about planning/organizing, 26 people (22.4\%)

indicated that judging team participation was almost essential in development of the skill, 44 respondents (37.9\%) said that it was highly influential, 33 individuals (28.5\%) responded that it was moderately influential, 11 persons $(9.5 \%)$ indicated that it was mildly influential, and two of those surveyed (1.7\%) said that it was not at all influential. In regard to the wise use of resources, 19 people (16.5\%) indicated that judging team participation was almost essential in development, 46 respondents (40.0\%) said that it was highly influential, 36 individuals (31.3\%) responded that it was moderately influential, 10 persons (8.7\%) indicated that it was mildly influential, and four of those surveyed (3.5\%) said that it was not at all influential.

With regard to questioning about keeping records, 32 people (27.8\%) indicated that judging team participation was almost essential in development, 38 respondents (33.0\%) said that it was highly influential, 30 individuals (26.1\%) responded that it was moderately influential, 11 persons (9.6\%) indicated that it was mildly influential, and four of those surveyed (3.5\%) said that it was not at all influential. When asked about resiliency, 22 individuals (19.1\%) said that judging team participation was almost essential in development, 40 people (34.8\%) indicated that it was highly influential, 34 of those surveyed (29.6\%) responded that it was moderately influential, 14 people $(12.2 \%)$ indicated that it was mildly influential, and the remaining five (4.4\%) said that it was not at all influential. 
Heart

Relating

When asked about communication skills, 44 individuals (38.3\%) said that judging team participation was almost essential in development of the skill, 42 people (36.5\%) indicated that it was highly influential, 22 of those surveyed (19.1\%) responded that it was moderately influential, five people (4.4\%) indicated that it was mildly influential, and two persons $(1.7 \%)$ said that it was not at all influential. In regard to questioning about cooperation, 42 respondents (36.5\%) indicated that judging team participation was almost essential in development, 43 people (37.4\%) said that it was highly influential, 22 of those surveyed (19.1\%) responded that it was moderately influential, six individuals (5.2\%) indicated that it was mildly influential, and two people (1.7\%) said that it was not at all influential.

With regard to social skills, 50 respondents (43.5\%) indicated that judging team participation was almost essential in development, 33 people (28.7\%) said that it was highly influential, 20 of those surveyed (17.4\%) responded that it was moderately influential, 10 individuals (8.7\%) indicated that it was mildly influential, and two people (1.7\%) said that it was not at all influential. When asked about conflict resolution skills, 15 people (13.0\%) indicated that judging team participation was almost essential in development, 43 respondents (37.4\%) said that it was highly influential, 34 individuals (29.6\%) responded that it was moderately influential, 16 persons (13.9\%) indicated that it was mildly influential, and seven of those surveyed (6.1\%) said that it was not at all influential. 
When responding to questioning about accepting differences, 18 respondents (15.7\%) indicated that judging team participation was almost essential in development, 46 individuals (40.0\%) responded that it was highly influential, 33 respondents (28.7\%) said that it was moderately influential, and nine people (7.8\%) indicated that it was mildly influential. The remaining nine of those surveyed (7.8\%) said that it was not at all influential.

\section{Caring}

In regard to concern for others, 18 respondents (15.7\%) indicated that judging team participation was almost essential in development, 39 individuals (33.9\%) responded that it was highly influential, 31 respondents (27.0\%) said that it was moderately influential, and 19 people (16.5\%) indicated that it was mildly influential. Eight persons (7.0\%) said that it was not at all influential.

When questioned about empathy, 10 individuals (8.7\%) said that judging team participation was almost essential in development of the skill, 41 people (35.7\%) indicated that it was highly influential, 30 of those surveyed (26.1\%) responded that it was moderately influential, 25 people (21.7\%) indicated that it was mildly influential, and the remaining nine (7.8\%) said that it was not at all influential. When asked about sharing, 31 individuals (27.0\%) said that judging team participation was almost essential in development of the skill, 33 people (28.7\%) indicated that it was highly influential, 30 of those surveyed (26.1\%) responded that it was moderately influential, 16 people (13.9\%) indicated that it was mildly influential, and five persons (4.4\%) said that it was not at all influential. 
Lastly, in regard to nurturing relationships, 23 respondents (20.0\%) indicated that judging team participation was almost essential in development of the skill, 37 individuals (32.2\%) responded that it was highly influential, 31 respondents (27.0\%) said that it was moderately influential, 16 people (13.9\%) indicated that it was mildly influential, and the remaining eight people (7.0\%) said that it was not at all influential (see Table 16).

Table 16

Influence of 4-H Judging Team Participation on Development of Life Skills

\begin{tabular}{|c|c|c|c|c|c|c|c|c|c|c|}
\hline & \multicolumn{2}{|c|}{$\begin{array}{l}\text { Not at all } \\
\text { influential }\end{array}$} & \multicolumn{2}{|c|}{$\begin{array}{c}\text { Mildly } \\
\text { influential }\end{array}$} & \multicolumn{2}{|c|}{$\begin{array}{c}\text { Moderately } \\
\text { influential }\end{array}$} & \multicolumn{2}{|c|}{$\begin{array}{l}\text { Highly } \\
\text { influential }\end{array}$} & \multicolumn{2}{|c|}{$\begin{array}{c}\text { Almost } \\
\text { essential }\end{array}$} \\
\hline & $\mathrm{N}$ & $\%$ & $\mathrm{~N}$ & $\%$ & $\mathrm{~N}$ & $\%$ & $\mathrm{~N}$ & $\%$ & $\mathrm{~N}$ & $\%$ \\
\hline \multicolumn{11}{|l|}{ Community } \\
\hline \multicolumn{11}{|l|}{ Service/ } \\
\hline Volunteering & 6 & 5.22 & 16 & 13.91 & 32 & 27.83 & 48 & 41.74 & 13 & 11.30 \\
\hline Leadership & 1 & .86 & 9 & 7.76 & 25 & 21.55 & 54 & 46.55 & 27 & 23.28 \\
\hline \multicolumn{11}{|l|}{ Responsible } \\
\hline Citizenship & 2 & 1.72 & 10 & 8.62 & 38 & 32.76 & 43 & 37.07 & 23 & 19.83 \\
\hline $\begin{array}{l}\text { Contributions } \\
\text { to Group Effort }\end{array}$ & 2 & 1.72 & 3 & 2.59 & 19 & 16.38 & 44 & 37.93 & 48 & 41.38 \\
\hline \multicolumn{11}{|l|}{ Marketable } \\
\hline Skills & 1 & .87 & 10 & 8.70 & 29 & 25.22 & 56 & 48.70 & 19 & 16.52 \\
\hline Teamwork & 1 & .88 & 2 & 1.75 & 21 & 18.42 & 33 & 28.95 & 57 & 50.00 \\
\hline Self-Motivation & 2 & 1.72 & 7 & 6.03 & 22 & 18.97 & 43 & 37.07 & 42 & 36.21 \\
\hline Self-Esteem & 3 & 2.59 & 5 & 4.31 & 26 & 22.41 & 54 & 46.55 & 28 & 24.14 \\
\hline \multicolumn{11}{|l|}{ Self- } \\
\hline Responsibility & 1 & .86 & 7 & 6.03 & 25 & 21.55 & 45 & 38.79 & 38 & 32.76 \\
\hline
\end{tabular}


Table 16 (continued)

Influence of 4-H Judging Team Participation on Development of Life Skills

\begin{tabular}{|c|c|c|c|c|c|c|c|c|c|c|}
\hline & \multicolumn{2}{|c|}{$\begin{array}{l}\text { Not at all } \\
\text { influential }\end{array}$} & \multicolumn{2}{|c|}{$\begin{array}{c}\text { Mildly } \\
\text { influential }\end{array}$} & \multicolumn{2}{|c|}{$\begin{array}{c}\text { Moderately } \\
\text { influential }\end{array}$} & \multicolumn{2}{|c|}{$\begin{array}{c}\text { Highly } \\
\text { influential }\end{array}$} & \multicolumn{2}{|c|}{$\begin{array}{c}\text { Almost } \\
\text { essential }\end{array}$} \\
\hline & $\mathrm{N}$ & $\%$ & $\mathrm{~N}$ & $\%$ & $\mathrm{~N}$ & $\%$ & $\mathrm{~N}$ & $\%$ & $\mathrm{~N}$ & $\%$ \\
\hline Character & 1 & .87 & 11 & 9.57 & 24 & 20.87 & 40 & 34.78 & 39 & 33.91 \\
\hline \multicolumn{11}{|l|}{ Managing } \\
\hline Feelings & 5 & 4.31 & 21 & 18.10 & 30 & 25.86 & 41 & 35.34 & 19 & 16.38 \\
\hline Self-Discipline & 2 & 1.72 & 10 & 8.62 & 31 & 26.72 & 40 & 34.48 & 33 & 28.45 \\
\hline \multicolumn{11}{|l|}{ Healthy } \\
\hline \multicolumn{11}{|l|}{ Lifestyle } \\
\hline Choices & 23 & 20.00 & 24 & 20.87 & 41 & 35.65 & 21 & 18.26 & 6 & 5.22 \\
\hline \multicolumn{11}{|l|}{ Stress } \\
\hline Management & 2 & 1.72 & 24 & 20.69 & 49 & 42.24 & 30 & 25.86 & 11 & 9.48 \\
\hline \multicolumn{11}{|l|}{ Disease } \\
\hline Prevention & 25 & 21.74 & 34 & 29.57 & 33 & 28.70 & 14 & 12.17 & 9 & 7.83 \\
\hline Personal Safety & 15 & 12.93 & 26 & 22.41 & 33 & 28.45 & 30 & 25.86 & 12 & 10.34 \\
\hline \multicolumn{11}{|l|}{ Learning to } \\
\hline Learn & 1 & .86 & 4 & 3.45 & 17 & 14.66 & 55 & 47.41 & 39 & 33.62 \\
\hline \multicolumn{11}{|l|}{ Decision } \\
\hline Making & 1 & .86 & 5 & 4.31 & 23 & 19.83 & 41 & 35.34 & 46 & 39.66 \\
\hline \multicolumn{11}{|l|}{ Problem } \\
\hline Solving & 1 & .86 & 9 & 7.76 & 28 & 24.14 & 43 & 37.07 & 35 & 30.17 \\
\hline \multicolumn{11}{|l|}{ Critical } \\
\hline Thinking & 1 & .86 & 8 & 6.90 & 24 & 20.69 & 43 & 37.07 & 40 & 34.48 \\
\hline \multicolumn{11}{|l|}{ Service } \\
\hline Learning & 4 & 3.45 & 13 & 11.21 & 28 & 24.14 & 41 & 35.34 & 30 & 25.86 \\
\hline
\end{tabular}


Table 16 (continued)

Influence of 4-H Judging Team Participation on Development of Life Skills

\begin{tabular}{|c|c|c|c|c|c|c|c|c|c|c|}
\hline & \multicolumn{2}{|c|}{$\begin{array}{l}\text { Not at all } \\
\text { influential }\end{array}$} & \multicolumn{2}{|c|}{$\begin{array}{c}\text { Mildly } \\
\text { influential }\end{array}$} & \multicolumn{2}{|c|}{$\begin{array}{l}\text { Moderately } \\
\text { influential }\end{array}$} & \multicolumn{2}{|c|}{$\begin{array}{c}\text { Highly } \\
\text { influential }\end{array}$} & \multicolumn{2}{|c|}{$\begin{array}{c}\text { Almost } \\
\text { essential }\end{array}$} \\
\hline & $\mathrm{N}$ & $\%$ & $\mathrm{~N}$ & $\%$ & $\mathrm{~N}$ & $\%$ & $\mathrm{~N}$ & $\%$ & $\mathrm{~N}$ & $\%$ \\
\hline Goal Setting & 1 & .86 & 9 & 7.76 & 31 & 26.72 & 45 & 38.79 & 30 & 25.86 \\
\hline \multicolumn{11}{|l|}{ Planning/ } \\
\hline Organizing & 2 & 1.72 & 11 & 9.48 & 33 & 28.45 & 44 & 37.93 & 26 & 22.41 \\
\hline Wise Use of & & & & & & & & & & \\
\hline Resources & 4 & 3.48 & 10 & 8.70 & 36 & 31.30 & 46 & 40.00 & 19 & 16.52 \\
\hline \multicolumn{11}{|l|}{ Keeping } \\
\hline Records & 4 & 3.48 & 11 & 9.57 & 30 & 26.09 & 38 & 33.04 & 32 & 27.83 \\
\hline Resiliency & 5 & 4.35 & 14 & 12.17 & 34 & 29.57 & 40 & 34.78 & 22 & 19.13 \\
\hline Communication & 2 & 1.74 & 5 & 4.35 & 22 & 19.13 & 42 & 36.52 & 44 & 38.26 \\
\hline Cooperation & 2 & 1.74 & 6 & 5.22 & 22 & 19.13 & 43 & 37.39 & 42 & 36.52 \\
\hline Social Skills & 2 & 1.74 & 10 & 8.70 & 20 & 17.39 & 33 & 28.70 & 50 & 43.48 \\
\hline \multicolumn{11}{|l|}{ Conflict } \\
\hline Resolution & 7 & 6.09 & 16 & 13.91 & 34 & 29.57 & 43 & 37.39 & 15 & 13.04 \\
\hline \multicolumn{11}{|l|}{ Accepting } \\
\hline Differences & 9 & 7.83 & 9 & 7.83 & 33 & 28.70 & 46 & 40.00 & 18 & 15.65 \\
\hline \multicolumn{11}{|l|}{ Concern for } \\
\hline Others & 8 & 6.96 & 19 & 16.52 & 31 & 26.96 & 39 & 33.91 & 18 & 15.65 \\
\hline Empathy & 9 & 7.83 & 25 & 21.74 & 30 & 26.09 & 41 & 35.65 & 10 & 8.70 \\
\hline Sharing & 5 & 4.35 & 16 & 13.91 & 30 & 26.09 & 33 & 28.70 & 31 & 26.96 \\
\hline \multicolumn{11}{|l|}{ Nurturing } \\
\hline Relationships & 8 & 6.96 & 16 & 13.91 & 31 & 26.96 & 37 & 32.17 & 23 & 20.00 \\
\hline
\end{tabular}


Respondents were asked how important life skills were in their current jobs.

Following is a description of their responses.

Hands

Giving

When asked about community service/volunteering, 25 individuals (21.7\%)

responded that it was almost essential and highly important in their current job, 32 people (27.8\%) said that it was moderately important, 25 of those surveyed (21.7\%) reported that it was mildly important, and eight individuals (7.0\%) said that it was not at all important. In regard to leadership skills, 60 people (52.2\%) responded that it was almost essential in their current job, 34 respondents (29.6\%) indicated that it was highly important, 16 individuals (13.9\%) said that it was moderately important, four of those surveyed (3.5\%) reported that leadership was mildly important, and one individual (0.9\%) said that it was not at all important.

With regard to responsible citizenship, 45 people (39.1\%) responded that it was almost essential in their current job, 41 respondents (35.7\%) indicated that it was highly important, 24 individuals (20.9\%) said that it was moderately important, four of those surveyed (3.5\%) reported that it was mildly important, and one individual (0.9\%) said that it was not at all important. When questioned about contributions to group effort, 69 people (60.5\%) responded that it was almost essential in their current job, 32 respondents (28.1\%) indicated that it was highly important, 11 individuals (9.7\%) said that it was moderately important, two of those surveyed (1.8\%) reported that contributions to group effort was mildly important, and none (0.0\%) said that it was not at all important. 


\section{Working}

When questioned regarding marketable skills, 68 people (59.1\%) said that it was almost essential in their current job, 35 respondents (30.4\%) indicated that it was highly important, 12 individuals (10.4\%) responded that it was moderately important, and none of those surveyed reported that it was mildly important or not at all important. In regard to questioning about teamwork, 73 people (64.0\%) responded that it was almost essential in their current job, 29 respondents (25.4\%) indicated that it was highly important, 10 individuals (8.8\%) said that it was moderately important, two of those surveyed (1.8\%) reported that it was mildly important, and none said that teamwork was not at all important.

In regard to self-motivation, 77 individuals (67.0\%) said that it was almost essential in their current job, 33 respondents (28.7\%) said that it was highly important, three people (2.6\%) responded that self-motivation was moderately important, and two of those surveyed (1.7\%) indicated that it was mildly important. None said that it was not at all important.

\section{Health}

Being

When asked about self-esteem, 41 individuals each (35.7\%) said that it was almost essential and highly important in their current job, 31 people (27.0\%) responded that it was moderately important, and two of those surveyed (1.7\%) indicated that it was mildly important. None said that it was not at all important.

When questioned about self-responsibility, 80 individuals (69.6\%) said that it was almost essential in their current job, 30 respondents (28.7\%) said that it was highly 
important, two people (1.7\%) responded that self-responsibility was moderately important, three of those surveyed (2.6\%) indicated that it was mildly important, and none said that it was not at all important. In regard to questioning about character, 69 of those surveyed (60.0\%) said that it was almost essential in their current job, 30 people (26.1\%) said that it was highly important, 13 respondents (11.3\%) indicated that it was moderately important, three individuals (2.6\%) said that it was mildly important, and none reported that character was not at all important.

In response to questioning about managing feelings, 52 of those surveyed (45.2\%) said that it was almost essential in their current job, 37 people (32.2\%) said that it was highly important, 22 respondents (19.1\%) indicated that it was moderately important, four individuals (3.5\%) said that managing feelings was mildly important, and none reported that it was not at all important. When asked about self-discipline, 72 of those surveyed (62.6\%) said that it was almost essential in their current job, 34 people (29.6\%) said that it was highly important, six respondents (5.2\%) indicated that it was moderately important, three individuals (2.6\%) said that it was mildly important, and none reported that it was not at all important.

\section{Living}

When asked about healthy lifestyle choices, 20 of those surveyed (17.5\%) said that they were almost essential in their current job, 36 people (31.6\%) said that they were highly important, 35 respondents (30.7\%) indicated that it was moderately important, 17 individuals (14.9\%) said that healthy lifestyle choices were mildly important, and six people (5.3\%) reported that they were not at all important. In regard to stress management, 57 people (49.6\%) reported that it was almost essential in their current job, 
36 individuals (31.3\%) said that it was highly important, 20 of those surveyed (17.4\%) said that it was moderately important, and one person each $(0.9 \%)$ reported that stress management was mildly important and not at all important.

With regard to disease prevention, 30 people (26.3\%) reported that it was almost essential in their current job, 25 individuals (21.9\%) said that it was highly important, 39 of those surveyed (34.2\%) said that it was moderately important, 14 individuals (12.3\%) indicated that disease prevention was mildly important, and six people (5.3\%) reported that it was not at all important. When questioned about personal safety, 53 people (46.5\%) reported that it was almost essential in their current job, 34 individuals (29.8\%) said that personal safety was highly important, 21 of those surveyed (18.4\%) said that it was moderately important, four individuals (3.5\%) indicated that it was mildly important, and two people (1.8\%) reported that it was not at all important.

\section{Head}

\section{Thinking}

When asked about learning to learn, 58 people (50.4\%) reported that it was almost essential in their current job, 46 individuals (40.0\%) said that it was highly important, nine of those surveyed (7.8\%) said that it was moderately important, two individuals (1.7\%) indicated that it was mildly important, and none reported that it was not at all important. In regard to questioning about decision making, 68 persons (59.7\%) indicated that it was almost essential in their current job, 38 individuals (33.3\%) reported that it was highly important, six people (5.3\%) said that it was moderately important, two of those surveyed (1.8\%) said that decision making was mildly important, and none reported that it was not at all important. 
When asked about problem solving, 83 persons (72.2\%) indicated that it was almost essential in their current job, 25 individuals 21.7\%) reported that it was highly important, six of those surveyed (5.2\%) said that it was moderately important, one person (0.9\%) said that it was mildly important, and none reported that it was not at all important. With regard to questioning about critical thinking, 75 persons (65.2\%) indicated that it was almost essential in their current job, 29 of those surveyed (25.2\%) reported that it was highly important, 10 people (8.7\%) said that it was moderately important, one individual (0.9\%) said that it was mildly important, and none reported that it was not at all important.

In response to questioning about service learning, 35 people each (30.4\%) indicated that it was almost essential and highly important in their current job, 28 people (24.4\%) said that it was moderately important, and 11 of those surveyed (9.6\%) said that it was mildly important. The remaining six respondents (5.2\%) reported that service learning was not at all important.

\section{Managing}

When questioned about goal setting, 53 individuals (49.1\%) indicated that it was almost essential in their current job, 39 respondents (33.9\%) reported that it was highly important, 18 people (15.7\%) said that it was moderately important, and four of those surveyed (3.5\%) said that it was mildly important. The remaining individual (0.9\%) reported that goal setting was not at all important.

In regard to planning/organizing, 66 individuals (57.4\%) indicated that it was almost essential in their current job, 38 respondents (33.0\%) reported that it was highly important, nine people (7.8\%) said that it was moderately important, two of those 
surveyed (1.7\%) said that it was mildly important, and none reported that planning/organizing was not at all important. When asked about the wise use of resources, 52 individuals (45.6\%) indicated that it was almost essential in their current job, 37 respondents (32.5\%) reported that it was highly important, 18 people (15.8\%) said that it was moderately important, six of those surveyed (5.3\%) said that it was mildly important, and one person (0.9\%) reported that the wise use of resources was not at all important.

With regard to keeping records, 70 people (61.4\%) said that it was almost essential in their current job, 31 of those surveyed (27.2\%) reported that keeping records was highly important, nine people (7.9\%) indicated that it was moderately important, four individuals (3.5\%) said that it was mildly important, and no respondents reported that it was not at all important. When asked about resiliency, 53 people (46.5\%) said that it was almost essential in their current job, 37 of those surveyed (32.5\%) reported that it was highly important, 20 people (17.5\%) indicated that it was moderately important, four individuals (3.5\%) said that it was mildly important, and no respondents reported that resiliency was not at all important.

Heart

Relating

In regard to questioning about communication, 76 people (66.7\%) said that it was almost essential in their current job, 31 of those surveyed (27.2\%) reported that it was highly important, six people (5.3\%) indicated that it was moderately important, one individual (0.9\%) said that it was mildly important, and no respondents reported that it was not at all important. In response to questioning about cooperation, 74 people (64.9\%) 
said that it was almost essential in their current job, 30 of those surveyed (26.3\%)

reported that it was highly important, nine people (7.9\%) indicated that cooperation was moderately important, no respondents said that it was mildly important, and one individual (0.9\%) reported that it was not at all important.

When asked about social skills, 63 people (55.3\%) said that it was almost essential in their current job, 36 of those surveyed (31.6\%) reported that it was highly important, 11 people (9.7\%) indicated that it was moderately important, three individuals (2.6\%) said that it was mildly important, and one respondent $(0.9 \%)$ reported that it was not at all important. In regard to conflict resolution, 56 people (49.1\%) said that it was almost essential in their current job, 43 of those surveyed (37.7\%) reported that it was highly important, 13 people (11.4\%) indicated that it was moderately important, and one individual each (0.9\%) said that it was mildly important and not at all important.

With regard to accepting differences, 48 individuals (42.1\%) said that it was almost essential in their current job, 35 of those surveyed (30.7\%) indicated that it was highly important, 24 people (21.1\%) said that it was moderately important, and three persons (2.6\%) said that it was mildly important. The remaining four respondents (3.5\%) reported that it was not at all important.

\section{Caring}

In regard to questioning about concern for others, 54 individuals (47.4\%) said that it was almost essential in their current job, 38 of those surveyed (33.3\%) indicated that it was highly important, 18 people (15.8\%) said that it was moderately important, and one person $(0.9 \%)$ said that concern for others was mildly important. Three respondents (2.6\%) reported that it was not at all important. 
In response to questioning about empathy, 48 individuals (42.5\%) said that it was almost essential in their current job, 33 of those surveyed (29.2\%) indicated that it was highly important, 24 people (21.2\%) said that empathy was moderately important, five persons (4.4\%) said that it was mildly important, and three respondents (2.6\%) reported that it was not at all important. In regard to sharing, 48 individuals (42.1\%) said that it was almost essential in their current job, 31 of those surveyed (27.2\%) indicated that it was highly important, 26 people (22.8\%) said that it was moderately important, six people (5.3\%) said that it was mildly important, and three respondents (2.6\%) reported that sharing was not at all important.

Finally, when asked about nurturing relationships, 54 people (47.4\%) said that it was almost essential in their current job, 26 of those surveyed (22.8\%) indicated that it was highly important, 24 people (21.1\%) said that it was moderately important, seven individuals (6.1\%) said that it was mildly important, and three respondents (2.6\%) reported that it was not at all important (see Table 17). 
Table 17

Importance of Life Skills in Respondents' Current Jobs

\begin{tabular}{cccccccccc}
\hline $\begin{array}{c}\text { Not at all } \\
\text { important }\end{array}$ & $\begin{array}{c}\text { Mildly } \\
\text { important }\end{array}$ & $\begin{array}{c}\text { Moderately } \\
\text { important }\end{array}$ & $\begin{array}{c}\text { Highly } \\
\text { important }\end{array}$ & $\begin{array}{c}\text { Almost } \\
\text { essential }\end{array}$ \\
\hline $\mathrm{N}$ & $\%$ & $\mathrm{~N}$ & $\%$ & $\mathrm{~N}$ & $\%$ & $\mathrm{~N}$ & $\%$ & $\mathrm{~N}$ & $\%$ \\
\hline
\end{tabular}

Community

Service/

$\begin{array}{lllllllllll}\text { Volunteering } & 8 & 6.96 & 25 & 21.74 & 32 & 27.83 & 25 & 21.74 & 25 & 21.74\end{array}$

$\begin{array}{lllllllllll}\text { Leadership } & 1 & .87 & 4 & 3.48 & 16 & 13.91 & 34 & 29.57 & 60 & 52.17\end{array}$

Responsible

$\begin{array}{lllllllllll}\text { Citizenship } & 1 & .87 & 4 & 3.48 & 24 & 20.87 & 41 & 35.65 & 45 & 39.13\end{array}$

Contributions

$\begin{array}{lllllllllll}\text { to Group Effort } & 0 & .00 & 2 & 1.75 & 11 & 9.65 & 32 & 28.07 & 69 & 60.53\end{array}$

Marketable

$\begin{array}{lllllllllll}\text { Skills } & 0 & .00 & 0 & .00 & 12 & 10.43 & 35 & 30.43 & 68 & 59.13\end{array}$

$\begin{array}{lllllllllll}\text { Teamwork } & 0 & .00 & 2 & 1.75 & 10 & 8.77 & 29 & 25.44 & 73 & 64.04\end{array}$

$\begin{array}{lllllllllll}\text { Self-Motivation } & 0 & .00 & 2 & 1.74 & 3 & 2.61 & 33 & 28.70 & 77 & 66.96\end{array}$

$\begin{array}{lllllllllll}\text { Self-Esteem } & 0 & .00 & 2 & 1.74 & 31 & 26.96 & 41 & 35.65 & 41 & 35.65\end{array}$

Self-

$\begin{array}{lllllllllll}\text { Responsibility } & 0 & .00 & 3 & 2.61 & 2 & 1.74 & 30 & 26.09 & 80 & 69.57\end{array}$

$\begin{array}{lllllllllll}\text { Character } & 0 & .00 & 3 & 2.61 & 13 & 11.30 & 30 & 26.09 & 69 & 60.00\end{array}$

Managing

$\begin{array}{lllllllllll}\text { Feelings } & 0 & .00 & 4 & 3.48 & 22 & 19.13 & 37 & 32.17 & 52 & 45.22\end{array}$

$\begin{array}{lllllllllll}\text { Self-Discipline } & 0 & .00 & 3 & 2.61 & 6 & 5.22 & 34 & 29.57 & 72 & 62.61\end{array}$

Healthy

Lifestyle

Choices

$\begin{array}{llllllllll}6 & 5.26 & 17 & 14.91 & 35 & 30.70 & 36 & 31.58 & 20 & 17.54\end{array}$ 
Table 17 (continued)

Importance of Life Skills in Respondents' Current Jobs

\begin{tabular}{|c|c|c|c|c|c|c|c|c|c|c|}
\hline & \multicolumn{2}{|c|}{$\begin{array}{l}\text { Not at all } \\
\text { important }\end{array}$} & \multicolumn{2}{|c|}{$\begin{array}{c}\text { Mildly } \\
\text { important }\end{array}$} & \multicolumn{2}{|c|}{$\begin{array}{l}\text { Moderately } \\
\text { important }\end{array}$} & \multicolumn{2}{|c|}{$\begin{array}{c}\text { Highly } \\
\text { important }\end{array}$} & \multicolumn{2}{|c|}{$\begin{array}{c}\text { Almost } \\
\text { essential }\end{array}$} \\
\hline & $\mathrm{N}$ & $\%$ & $\mathrm{~N}$ & $\%$ & $\mathrm{~N}$ & $\%$ & $\mathrm{~N}$ & $\%$ & $\mathrm{~N}$ & $\%$ \\
\hline \multicolumn{11}{|l|}{ Stress } \\
\hline Management & 1 & .87 & 1 & .87 & 20 & 17.39 & 36 & 31.30 & 57 & 49.57 \\
\hline \multicolumn{11}{|l|}{ Disease } \\
\hline Prevention & 6 & 5.26 & 14 & 12.28 & 39 & 34.21 & 25 & 21.93 & 30 & 26.32 \\
\hline Personal Safety & 2 & 1.75 & 4 & 3.51 & 21 & 18.42 & 34 & 29.82 & 53 & 46.49 \\
\hline \multicolumn{11}{|l|}{ Learning to } \\
\hline Learn & 0 & .00 & 2 & 1.74 & 9 & 7.83 & 46 & 40.00 & 58 & 50.43 \\
\hline \multicolumn{11}{|l|}{ Decision } \\
\hline Making & 0 & .00 & 2 & 1.75 & 6 & 5.26 & 38 & 33.33 & 68 & 59.65 \\
\hline \multicolumn{11}{|l|}{ Problem } \\
\hline Solving & 0 & .00 & 1 & .87 & 6 & 5.22 & 25 & 21.74 & 83 & 72.17 \\
\hline \multicolumn{11}{|l|}{ Critical } \\
\hline Thinking & 0 & .00 & 1 & .87 & 10 & 8.70 & 29 & 25.22 & 75 & 65.22 \\
\hline \multicolumn{11}{|l|}{ Service } \\
\hline Learning & 6 & 5.22 & 11 & 9.57 & 28 & 24.35 & 35 & 30.43 & 35 & 30.43 \\
\hline Goal Setting & 1 & .87 & 4 & 3.48 & 18 & 15.65 & 39 & 33.91 & 53 & 46.09 \\
\hline \multicolumn{11}{|l|}{ Planning/ } \\
\hline Organizing & 0 & .00 & 2 & 1.74 & 9 & 7.83 & 38 & 33.04 & 66 & 57.39 \\
\hline \multicolumn{11}{|l|}{ Wise Use of } \\
\hline Resources & 1 & .88 & 6 & 5.26 & 18 & 15.79 & 37 & 32.46 & 52 & 45.61 \\
\hline \multicolumn{11}{|l|}{ Keeping } \\
\hline Records & 0 & .00 & 4 & 3.51 & 9 & 7.89 & 31 & 27.19 & 70 & 61.40 \\
\hline
\end{tabular}


Table 17 (continued)

Importance of Life Skills in Respondents' Current Jobs

\begin{tabular}{|c|c|c|c|c|c|c|c|c|c|c|}
\hline & \multicolumn{2}{|c|}{$\begin{array}{l}\text { Not at all } \\
\text { important }\end{array}$} & \multicolumn{2}{|c|}{$\begin{array}{c}\text { Mildly } \\
\text { important }\end{array}$} & \multicolumn{2}{|c|}{$\begin{array}{l}\text { Moderately } \\
\text { important }\end{array}$} & \multicolumn{2}{|c|}{$\begin{array}{c}\text { Highly } \\
\text { important }\end{array}$} & \multicolumn{2}{|c|}{$\begin{array}{c}\text { Almost } \\
\text { essential }\end{array}$} \\
\hline & $\mathrm{N}$ & $\%$ & $\mathrm{~N}$ & $\%$ & $\mathrm{~N}$ & $\%$ & $\mathrm{~N}$ & $\%$ & $\mathrm{~N}$ & $\%$ \\
\hline Resiliency & 0 & .00 & 4 & 3.51 & 20 & 17.54 & 37 & 32.46 & 53 & 46.49 \\
\hline Communication & 0 & .00 & 1 & .88 & 6 & 5.26 & 31 & 27.19 & 76 & 66.67 \\
\hline Cooperation & 1 & .88 & 0 & .00 & 9 & 7.89 & 30 & 26.32 & 74 & 64.91 \\
\hline Social Skills & 1 & .88 & 3 & 2.63 & 11 & 9.65 & 36 & 31.58 & 63 & 55.26 \\
\hline \multicolumn{11}{|l|}{ Conflict } \\
\hline Resolution & 1 & .88 & 1 & .88 & 13 & 11.40 & 43 & 37.72 & 56 & 49.12 \\
\hline \multicolumn{11}{|l|}{ Accepting } \\
\hline Differences & 4 & 3.51 & 3 & 2.63 & 24 & 21.05 & 35 & 30.70 & 48 & 42.11 \\
\hline \multicolumn{11}{|l|}{ Concern for } \\
\hline Others & 3 & 2.63 & 1 & .88 & 18 & 15.79 & 38 & 33.33 & 54 & 47.37 \\
\hline Empathy & 3 & 2.65 & 5 & 4.42 & 24 & 21.24 & 33 & 29.20 & 48 & 42.48 \\
\hline Sharing & 3 & 2.63 & 6 & 5.26 & 26 & 22.81 & 31 & 27.19 & 48 & 42.11 \\
\hline \multicolumn{11}{|l|}{ Nurturing } \\
\hline Relationships & 3 & 2.63 & 7 & 6.14 & 24 & 21.05 & 26 & 22.81 & 54 & 47.37 \\
\hline
\end{tabular}




\section{CHAPTER V}

\section{Summary, Conclusions, and Recommendations}

\section{Purpose}

The purpose of this study was to determine how participation in West Virginia 4-H agricultural judging teams impacts life skills development. This study intends to determine the current life skill abilities of past 4-H state judging team winners from 1995 to 2006, determine how they perceive that ability was influenced by involvement on a judging team, and compare that with the importance of the various life skills in former participants' current jobs.

\section{Objectives}

The objectives of the study were:

1. To describe how participating as a part of a West Virginia 4-H state agricultural judging team impacts the development of life skills.

2. To describe how past West Virginia state 4-H judging team participants perceive their current level of life skill development.

3. To determine past West Virginia state 4-H judging teams members perceived importance of various life skills to their current job.

4. To describe how the life skills model used in 4-H programming relates to skills needed in employment situations. 


\section{Summary}

\section{Demographics}

Almost half of the respondents to this survey (48.3\%) fell between the ages of 26 and 30. Respondents were much more likely to have a Bachelor's or Master's degree than any other level of education, with 35.1\% having a Bachelor's degree and 26.3\% having a Master's degree. Two thirds of those who participated in the study worked at agriculturally related jobs or careers, and the majority wanted to stay in their current positions for the rest of their careers.

The average respondent participated in $4-\mathrm{H}$ for 10 years. At the local level, judging team participation ranged from an average of 1.4 years on forestry judging teams to an average of 5.3 years on livestock judging teams. Time spent participating on state judging teams was similar to that at the local level, ranging from an average of 1.3 years of participation for forestry judging teams to 5.2 years on poultry judging teams. The majority of participants spent only one year competing at the national level, and none spent more than two. Those on horticulture judging teams were the most likely to compete twice at the national level, making the average length of participation 1.3 years.

\section{Judging Team Practices and Experiences}

Survey participants were influenced by a number of different people in their decision to join 4-H. The most influential in this decision were parents, who were indicated as almost essential or as highly influential by $36.0 \%$ of respondents. Other 4-H members were likely to be highly influential (45.5\%), while teachers were mostly not at all influential (58.1\%) or only mildly influential (20.0\%). 
Extension agents were the individuals most chosen as being almost essential or highly influential in the decision to join 4-H judging teams (63.0\%). Parents and 4- $\mathrm{H}$ leaders were also influential, with parents listed as almost essential or highly influential by $57.2 \%$ of the individuals and $4-\mathrm{H}$ leaders listed as almost essential or highly influential by $52.9 \%$. Teachers (54.8\%) and siblings (48.1\%) were most likely to be noted as not at all influential.

When asked to identify those who taught respondents the skills needed to compete on 4-H judging teams, the most popular choices were extension agents, parents or guardians, and other 4-H members. Extension agents were indicated by $62.1 \%$ of respondents, parents or guardians were reported by $54.3 \%$, and other $4-\mathrm{H}$ members reported by $52.6 \%$ of the respondents.

Those who participated in the study were asked to rate their experiences on a number of paired adjective continuums. Respondents were more likely to find their experiences wonderful rather than terrifying, exciting rather than boring, and a learning experience rather than a waste of time. They were also more likely to find their experiences relaxing rather than stressful, but to a lesser degree than the other pairs.

The majority (88.2\%) of respondents practiced at least once a week before their state judging contest, practicing from once a week to daily. Practice increased before national contests, with (18.7\%) practicing daily, and fewer persons (16.8\%) practicing only once a week (as opposed to $30.0 \%$ before state contests). The majority of people (81.4\%) indicated that there were no consequences for missing practice.

Participation on a 4-H judging team did have some influence on education and career choices. For its influence on completing high school, 36.8\% of respondents 
indicated that their participation was at least moderately influential. For continuing education beyond high school, 43.9\% rated their judging team experience as being moderately influential or greater. For choice of college, $47.8 \%$ said it was at least moderately influential. Judging team participation did not influence many respondents to choose a college with a judging team - only $16.8 \%$ reported that it was a moderate influence or greater. In regards to career or job choice, however, $47.8 \%$ indicated that 4-H judging team participation was at least moderately influential on their decision (see Figure 3).

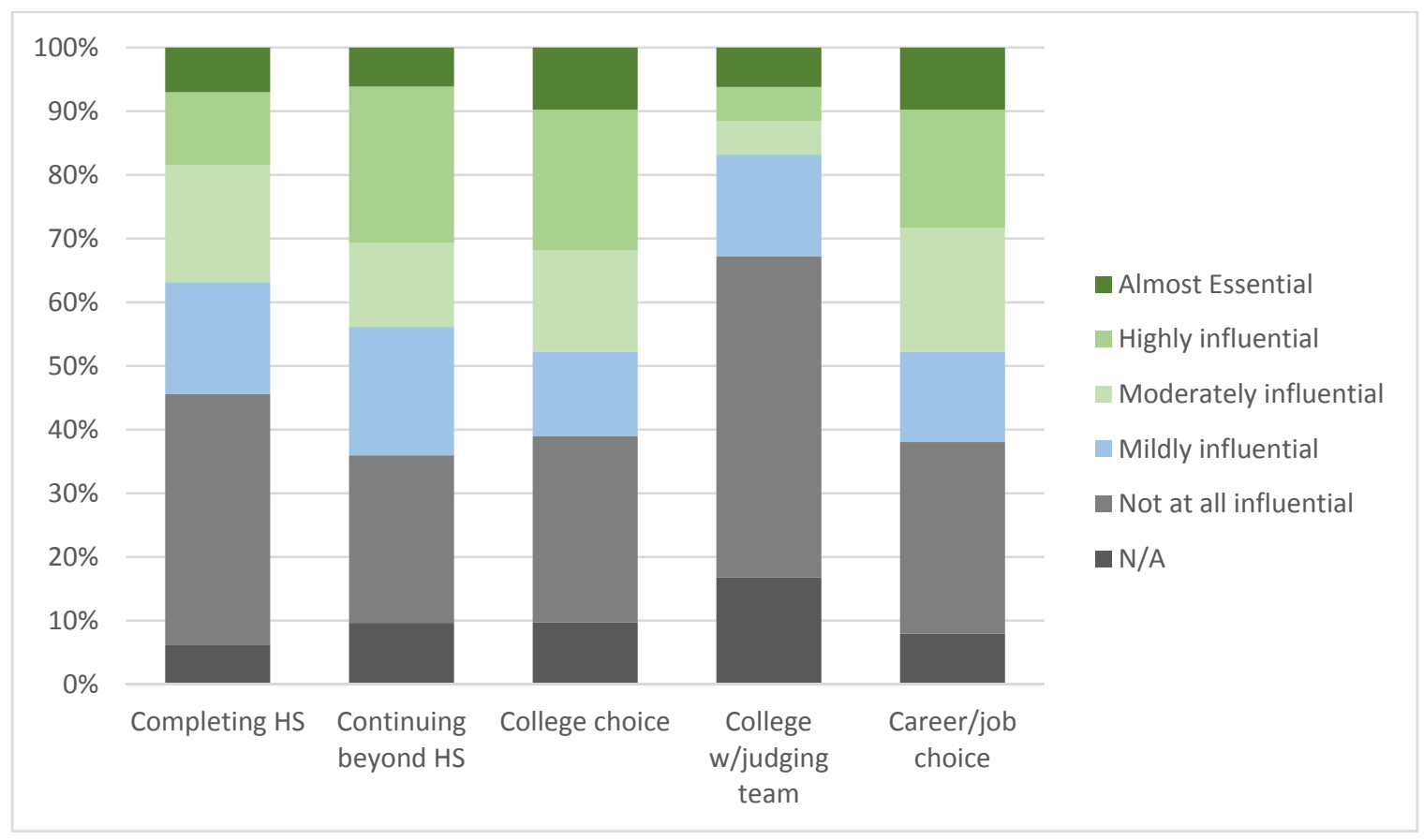

Figure 3

Judging Team Influence on Education and Career Choice

\section{Life Skills}

When rating their current skill levels in a list of 35 life skills, respondents were very likely to rate themselves as good or excellent. Even for stress management, the skill 
with the highest number of individuals rating themselves below good, $62.1 \%$ of the respondents rated their skill levels as either good or excellent. Other life skills that similarly stood out were community service/volunteering, with $32.8 \%$ of respondents rating themselves as average or below, and healthy lifestyle choices, with $31.0 \%$ of respondents rating themselves as average or below. Those skills in which people rated themselves most skilled included self-responsibility, with $62.1 \%$ of those surveyed rating themselves as excellent; character and self-motivation, both with 55.2\% people rating themselves as excellent; and marketable skills, with $51.7 \%$ of respondents rating themselves as excellent (see Figure 4). 


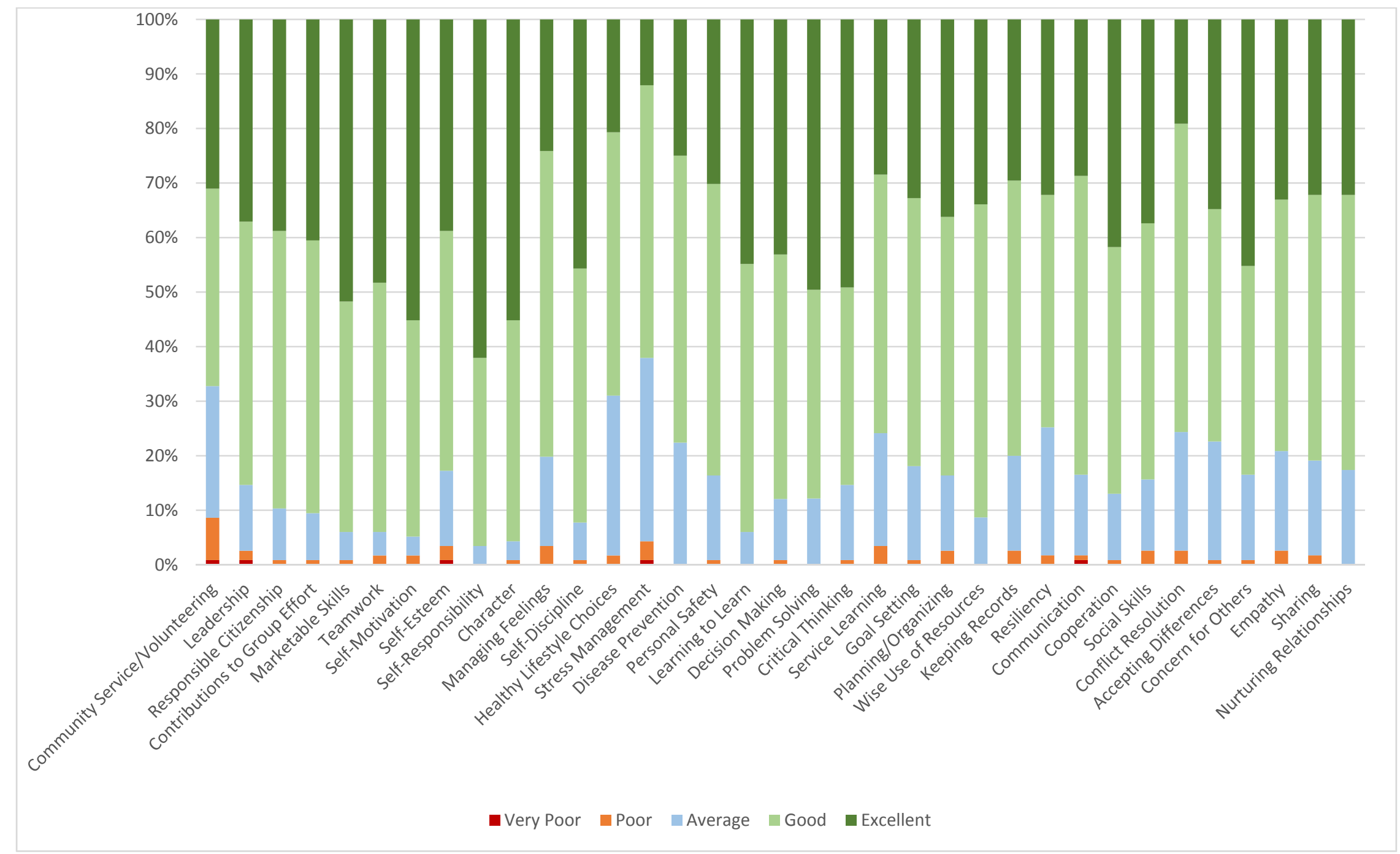

Figure 4

Current Skill Levels 
Participation on a 4-H judging team was perceived to have affected some life skills more than others. Those skills with the highest number of people rating their judging team experience as being highly influential or almost essential included learning to learn, with $81.0 \%$ of those surveyed rating $4-\mathrm{H}$ judging team participation as being either highly influential or almost essential to development of the skill; contributions to group effort, with $79.3 \%$ people indicating a rating of highly influential or almost essential; teamwork, with $79.0 \%$ people indicating a rating of highly influential or almost essential; and decision making, with $45.0 \%$ of those surveyed indicating a rating of highly influential or almost essential (see Figure 5).

Several skills were indicated to have been less influenced by 4-H judging team participation. For disease prevention, 51.3\% of those surveyed responded that their judging team experience was either mildly or not at all influential. Judging team participation was mildly or not at all effective in the development of healthy lifestyle choices for $40.9 \%$ of respondents. Personal safety had a similar amount of responses, with $35.3 \%$ of people giving a response of mildly or not at all influential (see Figure 5). 


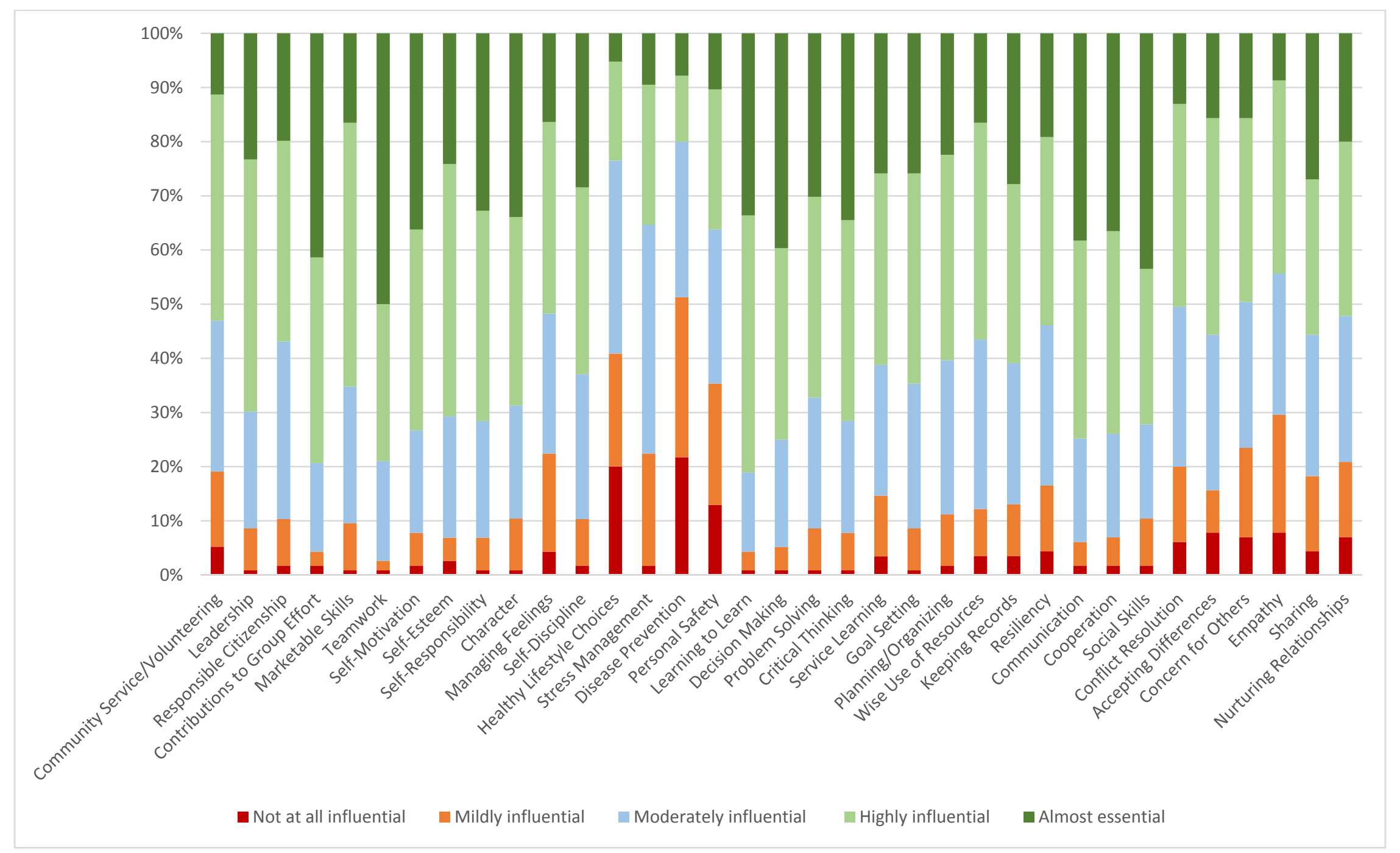

Figure 5

4-H Judging Team Influence on Development of Life Skills 
Many of the life skills were perceived to be important in respondents' current jobs. Those few life skills that stood out at all as having somewhat less importance in jobs - that is, with more than $10 \%$ of respondents indicating that they were either mildly or not at all important - were community service/volunteering (28.7\%), healthy lifestyle choices (20.2\%), disease prevention (17.5\%), and service learning (14.8\%).

The skill most often indicated as being almost essential in respondents’ current jobs was problem solving, with $72.2 \%$ of those surveyed answering to that effect. Both self-motivation and self-responsibility were also very important, with $95.7 \%(\mathrm{~N}=110)$ of respondents indicating that each skill was either highly important or almost essential (see Figure 6). 


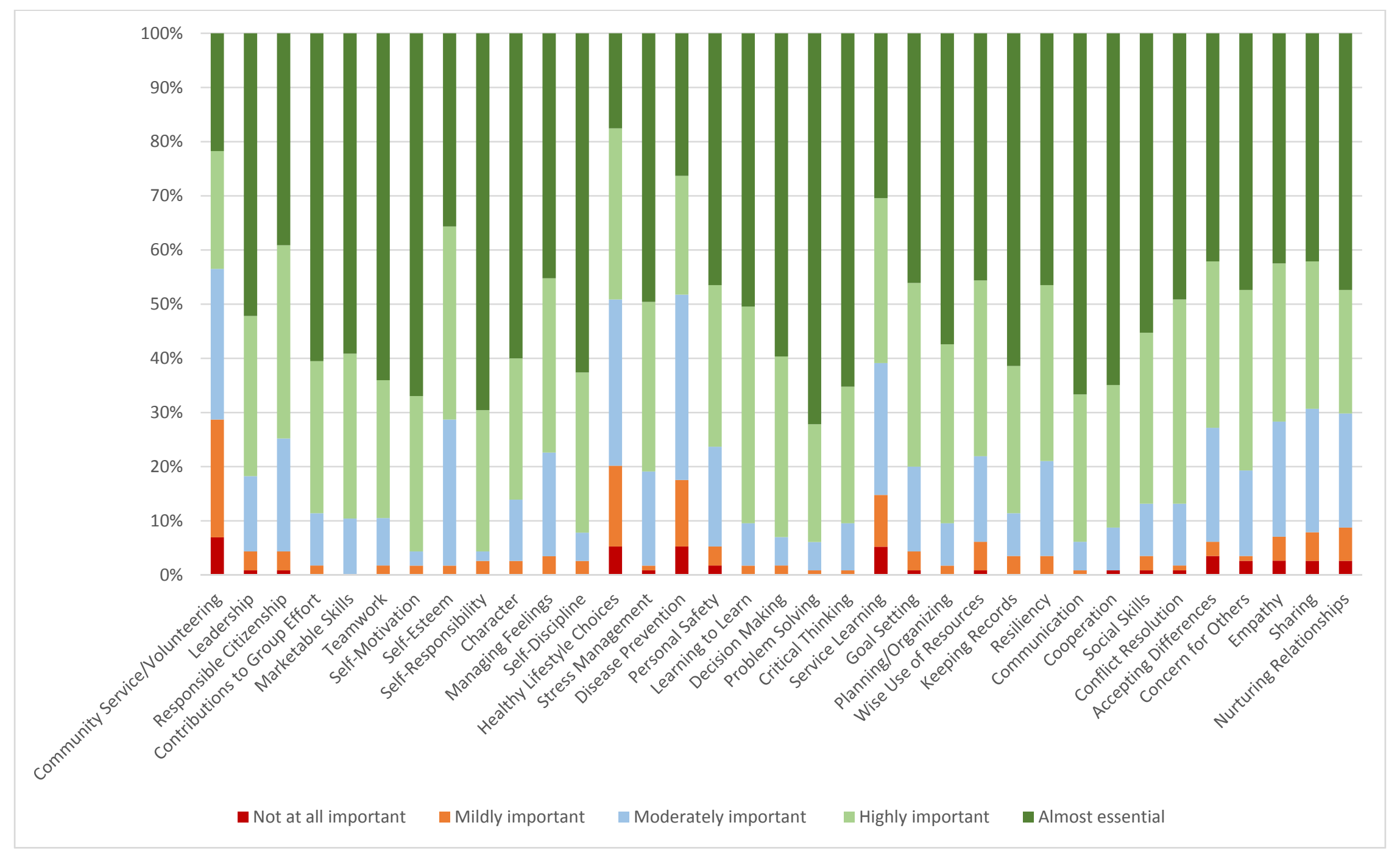

Figure 6

Life Skill Importance in Jobs 


\section{Conclusions}

Based on the findings of this study, the following conclusions were drawn:

1. Parents and other 4-H members are influential in recruiting youth to 4-H, 4-H judging teams, and in teaching the skills needed for participation on 4-H judging teams. Extension agents and 4-H leaders also influence youth after the youth have joined 4-H.

2. 4-H judging team participants come away from judging teams with a positive view of the experience.

3. Judging team participation has some influence on future choices about education and careers for roughly $40 \%$ of participants.

4. Over $90 \%$ of $4-\mathrm{H}$ judging team participants perceived their skills in all life skills to be at least average; over $60 \%$ perceived their skills to be at least good.

5. As a result of 4-H judging team participation, youths strengthened their abilities in numerous life skills, including learning to learn, contributions to group effort, teamwork, self-motivation, decision making, communication, cooperation, and social skills.

6. The life skills less likely to be influenced by $4-H$ judging team participation were often less likely to be perceived as important in jobs.

\section{Recommendations}

Based on the findings of this study, the following recommendations were made:

1. Parents and 4-H members should be encouraged in their roles as potential recruiters for 4-H and its programs and as educators for those already involved. 
2. More research is needed to determine the relationships that exist between life skills learned as a result of 4-H participation and those that are used in jobs and careers.

3. Participants on 4-H judging teams should be encouraged to participate in other 4-H programs and activities that focus on strengthening those life skills that judging teams teach less about, such as disease prevention, personal safety, healthy lifestyle choices, empathy, concern for others, and managing feelings.

4. Further research should be conducted to determine the skills employers perceive as being important in jobs. 


\section{REFERENCES}

Anderson, K. P. \& Karr-Lilienthal, L. (2011). Influence of 4-H horse project involvement on development of life skills. Journal of Extension, 49(5). Retrieved from http://www.joe.org/joe/2011october/iw2.php

Armstrong, W. A. (2010). Life skills development of youth participants in 4-H clubs and camping. (Master's Thesis). Retrieved from http://etd.fcla.edu/UF/UFE0042595/armstrong_w.pdf

Ary, D., Jacobs, L. C., \& Razavieh, A. (2002). Introduction to research in education. Belmont, CA: Wadsworth/Thomson Learning.

Astroth, K. A. (1996). Leadership in nonformal youth groups: Does style affect youth outcomes? Journal of Extension, 34(6). Retrieved from http://www.joe.org/joe/1996december/rb2.php

Boleman, C. T., Cummings, S. R., \& Briers, G. E. (2004). Parents' perceptions of life skills gained by youth participating in the 4-H beef project. Journal of Extension, 42(5). Retrieved from http://www.joe.org/joe/2004october/rb6.php

Boyd, B. L., Herring, D. R., \& Briers, G. E. (1992). Developing life skills in youth. Journal of Extension, 30(4). Retrieved from http://www.joe.org/joe/1992winter/a4.php

Dillman, D. A. (2000). Mail and internet surveys: the tailored design method. ( $2^{\text {nd }}$ ed.) New York: John Wiley \& Sons, Inc.

Everswick, M. E. (2011). An assessment of positive youth development within 4-H programs in Warren and Sussex county, New Jersey. (Master's Thesis). Retrieved from https://etda.libraries.psu.edu/paper/11525/7279

Fitzpatrick, C., Gagne, K. H., Jones, R., Lobley, J., \& Phelps, L. (2005). Life skills development in youth: Impact research in action. Journal of Extension, 43(3). Retreived from http://www.joe.org/joe/2005june/rb1.php

Flynn, A., Frick, M., \& Steele, D. (2010). Relationship between participation in 4-H and community leadership in rural Montana. Journal of Extension, 48(2). Retrieved from http://www.joe.org/joe/2010april/rb1.php

Fox, J., Schroeder, D., \& Lodl, K. (2003). Life skill development through 4-H clubs: the perspective of 4-H alumni. Journal of Extension, 41(6). Retrieved from http://www.joe.org/joe/2003december/rb2.php

Garton, M. S., Miltenberger, M., \& Pruett, B. (2007). Does 4-H camp influence life skill and leadership development? Journal of Extension, 45(4). Retrieved from http://www.joe.org/joe/2007august/a4.php 
Guthrie, L. D., \& Majeskie, J. L. (1997). Dairy cattle judging teaches critical life skills. Journal of Dairy Science, 80(8), 1884-1887.

Hendricks, P. (1996). 4-H life skills. Oklahoma State University. Retrieved from http://oklahoma4h.okstate.edu/litol/Docs/other/4H.VOL.135\%20Life\%20Skills\% 20Definitions_2012.pdf

Ladewig, H., \& Thomas, J. K. (1986). Assessing the impact of 4-H on former members. Texas A\&M University. Retrieved from http://files.eric.ed.gov/fulltext/ED282681.pdf

Lerner, R. M., \& Lerner, J. V. (2013). The positive development of youth: Comprehensive findings from the 4-H study of positive youth development. Retrieved from http://www.4-h.org/About-4-H/Research/PYD-Wave-9-2013.dwn

McCann, J. S., \& McCann, M. A. (1992). Judging team members reflection on the value of livestock, horse, meats, and wool judging programs. The Professional Animal Scientist, 8(3), 7-13.

Nash, S. A., \& Sant, L. L. (2005). Life-Skill Development Found in 4-H Animal Judging. Journal of Extension, 43(2). Retrieved from http://www.joe.org/joe/2005april/rb5.php

Potter, J. T., \& Mulroy, M. T. (1994). A tool to evaluate horse judging students perceptions of critical thinking and life skills development. NACTA Journal, 4243.

Radhakrishna, R. B., Everhart, L., \& Sinasky, M. (2006). Attitudes of 4-H participants about 4-H competitive events. Journal of Extension, 44(6). Retrieved from http://www.joe.org/joe/2006december/rb3.php

Robinson, J. P., Shaver, P. R., \& Wrightsman, L. S. (1991). Measures of personality and social psychological attitudes. New York: Academic Press.

Robinson, J. S. (2006). Graduates' and employers' perceptions of entry-level employability skills needed by agriculture, food and natural resources graduates. (Doctoral dissertation). Retrieved from https://mospace.umsystem.edu/xmlui/bitstream/handle/10355/4328/research.pdf?s equence $=3$

Rockwell, S. K., Stohler, R. F., \& Rudman, L. E. (1982). 4-H's influence on advanced training, careers and leadership roles in adulthood. Nebraska Cooperative Extension Service.

Rockwell, S. K., Stohler, R. F., \& Rudman, L. E. (1984). How 4-H Helps Career Development. Journal of Extension, 22(3). Retrieved from http://www.joe.org/joe/1984may/a1.php 
Rusk, C. P., Martin, C. A., Talbert, B. A., \& Balschweid, M. A. (2002). Attributes of Indiana's 4-H livestock judging program. Journal of Extension, 40(2). Retrieved from http://www.joe.org/joe/2002april/rb5.php

Rusk, C. P., Summerlot-Early, J. M., Machtmes, K. L., Talbert, B. A., \& Balschweid, M. A. (2003). The impact of raising and exhibiting selected 4-H livestock projects on the development of life and project skills. Journal of Agricultural Education, 44(3).

Seevers, B. S., \& Dormody, T. J. (1995). Leadership life skills development: Perceptions of senior 4-H youth. Journal of Extension, 33(4). Retrieved from http://www.joe.org/joe/1995august/rb1.php

Shurson, J. C., \& Lattner, C. L. (1991). Beyond livestock contests. Journal of Extension, 29(4). Retrieved from http://www.joe.org/joe/1991winter/rb5.php

Singletary, L., Smith, M., \& Evans, W. P. (2006). Self-perceived 4-H leader competencies and their relation to the skills youth learn through 4-H youth development programs. Journal of Extension, 44(4). Retrieved from http://www.joe.org/joe/2006august/rb2.php

True, A. C. (1928). A history of agricultural extension work in the United States 17851923. Washington, D.C.: United States Government Printing Office.

Walker, B. F. (2003). The impact of beef cattle projects on youth leadership and life skill development. (Master's Thesis). Retrieved from https://getd.libs.uga.edu/pdfs/walker_brandon_f_200612_mal.pdf

Ward, C. K. (1996). Life skill development related to participation in 4-H animal science projects. Journal of Extension, 34(2). Retrieved from http://www.joe.org/joe/1996april/rb2.php

Woloshuk, J. M., Kerns, M. J., \& Pennington, K. P. (1994). Assessing the impact of 4-H agricultural judging programs on 4-H members. Unpublished manuscript.

WVU Extension Service (n.d.). 4-H program philosophy. Retrieved from http://4hyd.ext.wvu.edu/about4h/whatis4h/4_h_program_philosophy 
APPENDICES 
APPENDIX A

Survey 


\title{
Impact of 4-H Judging Team Participation on Career Life Skills Development
}

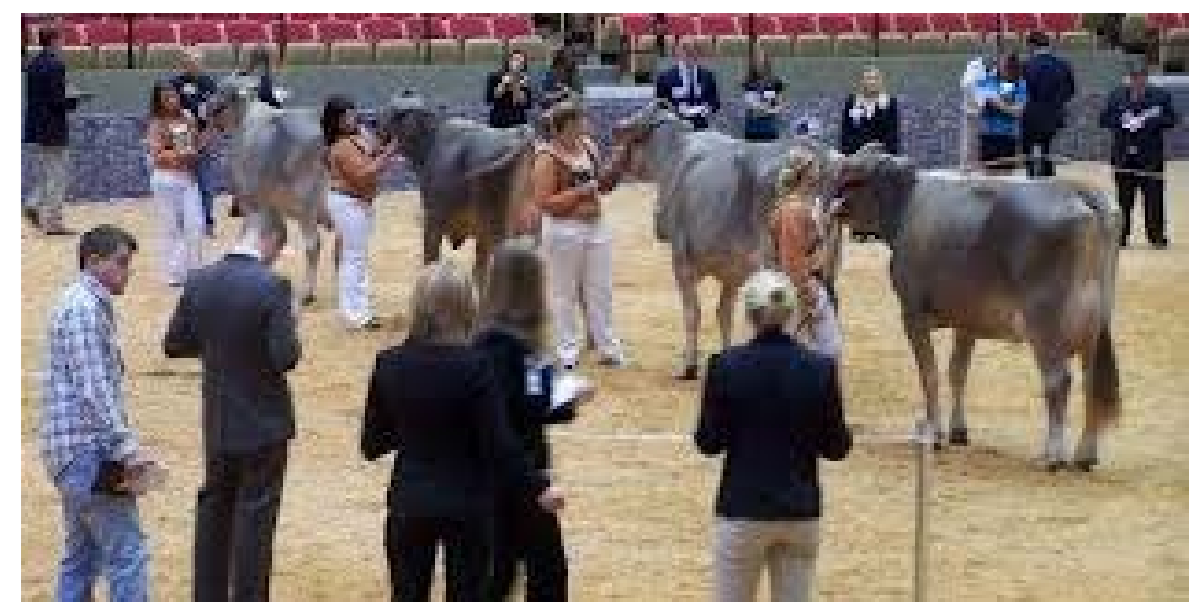

\author{
Evan Anderson \\ Graduate Student \\ Agricultural and Extension Education \\ Davis College of Agriculture, Natural Resources and Design \\ West Virginia University \\ Morgantown, WV 26505
}

2014 
Dear Past State 4-H Judging Team Winner:

As a past state 4-H judging team winner, you have experienced the importance of 4-H in your life. 4-H judging teams teach youth about agriculture and help to develop many life skills individuals need to thrive and prosper as adults. In an effort to establish the effects of 4-H judging teams in members' lives, it is important we look to former 4-H members to gain their perspective of how 4-H has impacted their lives. To reach that goal, your assistance is vital. Please consider your time spent with 4-H judging teams as you complete the following questions.

1. Please indicate the level to which the following individuals or groups of individuals had on you joining 4-H and on joining a 4-H judging team. (If not applicable, please use “not at all influential.”)

\begin{tabular}{|c|c|c|c|c|c|c|c|c|c|c|}
\hline & \multicolumn{5}{|c|}{ Influence on joining 4-H } & \multicolumn{5}{|c|}{$\begin{array}{c}\text { Influence on joining a } \\
4-\mathrm{H} \text { judging team }\end{array}$} \\
\hline & 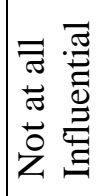 & 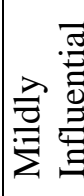 & 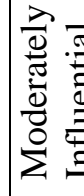 & 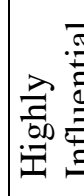 & 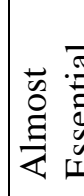 & 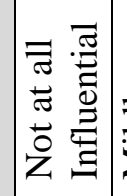 & 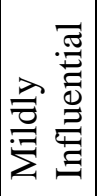 & 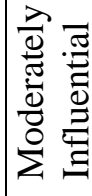 & 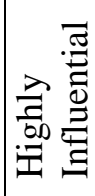 & 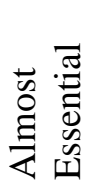 \\
\hline Parents & 1 & 2 & 3 & 4 & 5 & 1 & 2 & 3 & 4 & 5 \\
\hline Other 4-H members & 1 & 2 & 3 & 4 & 5 & 1 & 2 & 3 & 4 & 5 \\
\hline 4-H leader & 1 & 2 & 3 & 4 & 5 & 1 & 2 & 3 & 4 & 5 \\
\hline Teacher & 1 & 2 & 3 & 4 & 5 & 1 & 2 & 3 & 4 & 5 \\
\hline Brother/sister & 1 & 2 & 3 & 4 & 5 & 1 & 2 & 3 & 4 & 5 \\
\hline Extension agent & 1 & 2 & 3 & 4 & 5 & 1 & 2 & 3 & 4 & 5 \\
\hline Other (specify) & 1 & 2 & 3 & 4 & 5 & 1 & 2 & 3 & 4 & 5 \\
\hline
\end{tabular}


2. Which individual(s) or group of individuals taught you the skills needed for 4-H judging? (Check all that apply)

Parents/guardians

Other 4-H members

4-H leader

Teacher

Brother/sister

Extension agent

Other (specify)

3. Using the following adjective pairs please describe your experiences as a member of a 4-H judging team. For example, if your experiences were very stressful, you may want to circle a "1." If you felt totally relaxed and absolutely no pressure, you would circle a " 5 ." If your experiences were somewhere in between, circle the appropriate number. Continue on to the next three pairs of adjectives.

Stressful

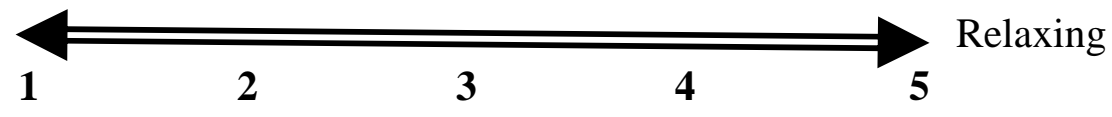

Terrifying

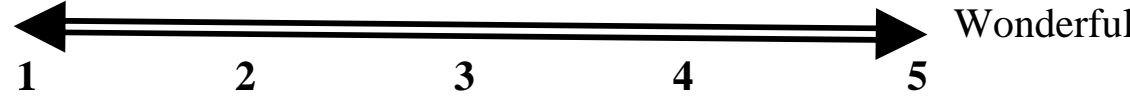

Boring
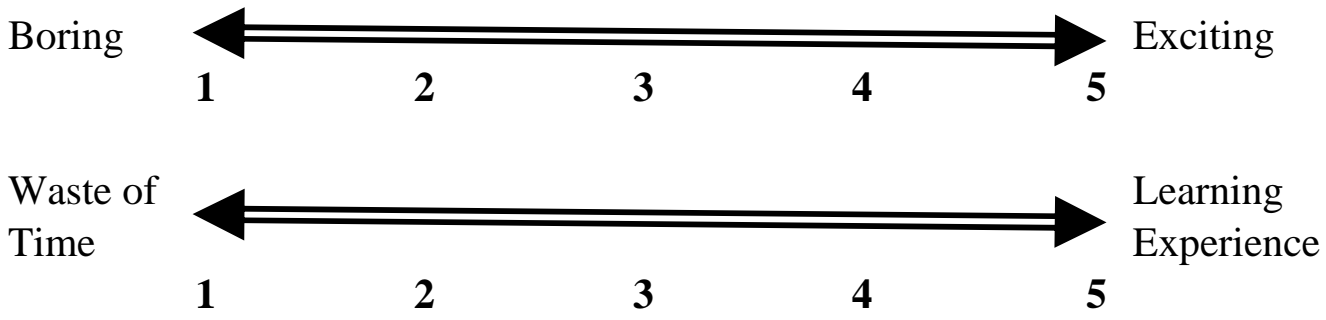
4. How frequently did your state judging team practice? (select the category that best fits)

\begin{tabular}{|c|c|c|c|c|c|c|}
\hline & $\stackrel{\vec{\nexists}}{\overrightarrow{\tilde{\Xi}}}$ & 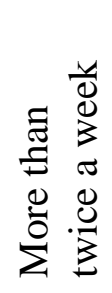 & 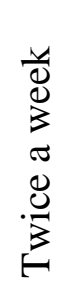 & 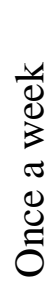 & 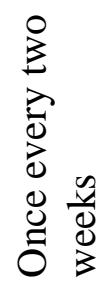 & 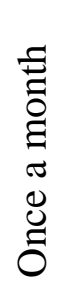 \\
\hline Before state contest & 1 & 2 & 3 & 4 & 5 & 6 \\
\hline Before national contest & 1 & 2 & 3 & 4 & 5 & 6 \\
\hline
\end{tabular}

5. Were there consequences if you missed judging practice prior to the state judging event?

No

Yes, (please specify the consequence(s))

6. How much did taking part in the 4-H judging team influence the following...?

\begin{tabular}{|c|c|c|c|c|c|c|}
\hline & 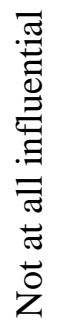 & 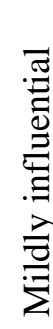 & 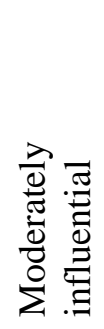 & 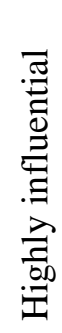 & 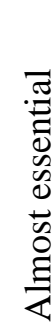 & 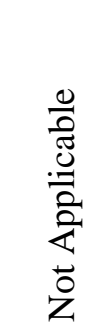 \\
\hline Completing your high school education? & 1 & 2 & 3 & 4 & 5 & N/A \\
\hline $\begin{array}{l}\text { Continuing education beyond high } \\
\text { school? }\end{array}$ & 1 & 2 & 3 & 4 & 5 & N/A \\
\hline Your choice of college? & 1 & 2 & 3 & 4 & 5 & N/A \\
\hline Choosing a college with a judging team? & 1 & 2 & 3 & 4 & 5 & N/A \\
\hline Your choice of job or career? & 1 & 2 & 3 & 4 & 5 & $\mathrm{~N} / \mathrm{A}$ \\
\hline
\end{tabular}


7. On the following pages, please indicate your current level of ability, how influential participating in a judging team was on development, and how important the skill is in your current job for each life skill. For example, if you feel your leadership skills are good, participation in a judging team was moderately influential in developing your leadership skills, and leadership skills are highly important in your current job, circle the number 4 under "What is your current level of ability in this skill area?", the number 3 under "How influential was participation on 4-H judging teams on your development of each skill?", and the number 4 under "How important is this skill in your current job?" for the "Leadership” row of the chart. 


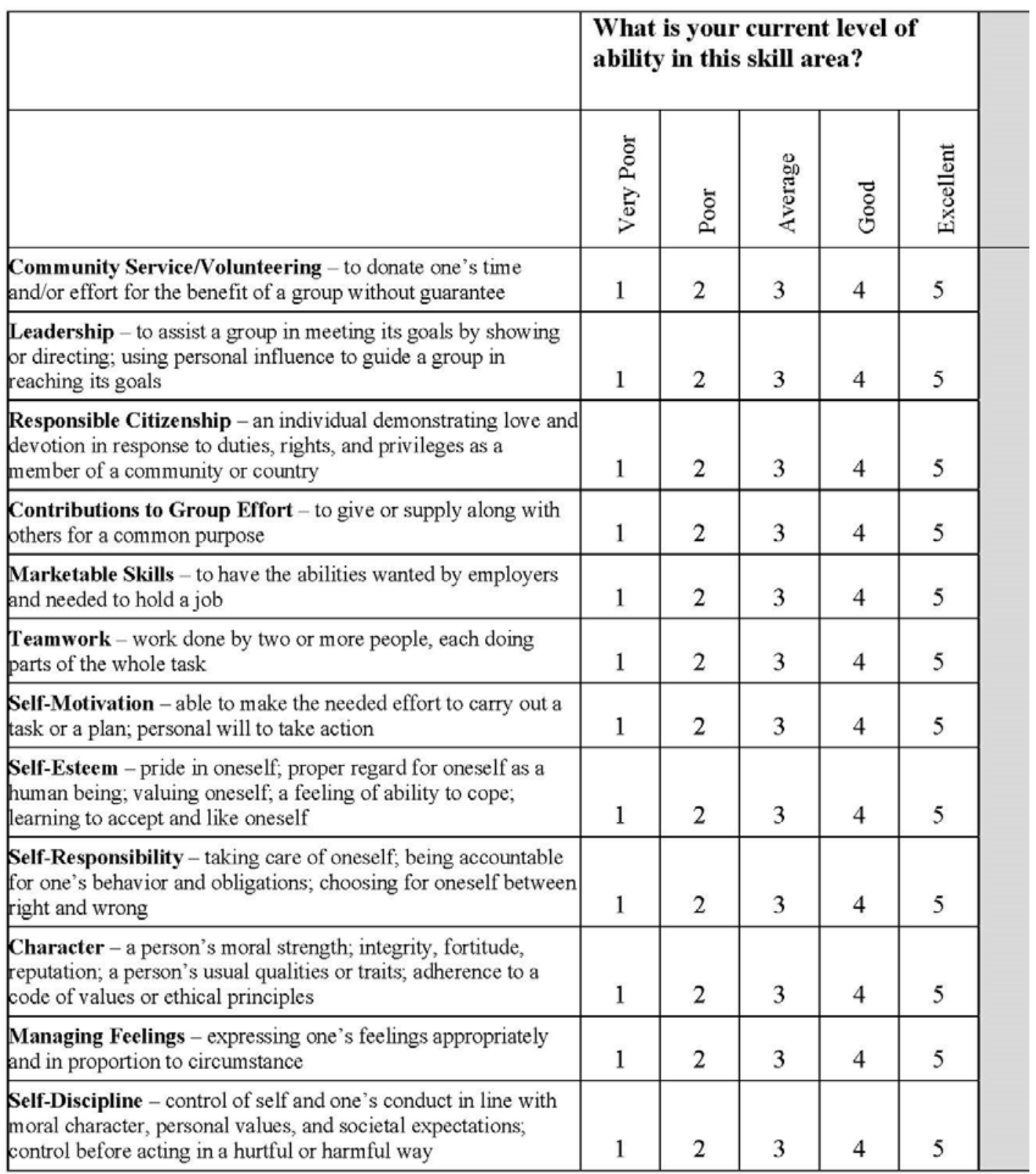




\begin{tabular}{|c|c|c|c|c|c|c|c|c|c|}
\hline \multicolumn{5}{|c|}{$\begin{array}{l}\text { How influential was participation } \\
\text { on } 4 \text {-H judging teams on your } \\
\text { development of each skill? }\end{array}$} & \multicolumn{5}{|c|}{$\begin{array}{l}\text { How important is this skill in your } \\
\text { current job? }\end{array}$} \\
\hline 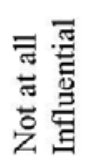 & 莺莺 & 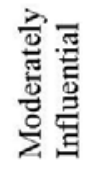 & 茎 & $\begin{array}{l}\text { 焉 } \\
\text { 焉 } \\
\text { 的 }\end{array}$ & 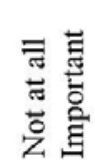 & 㟒壱 & 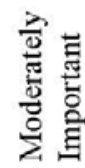 & 总焉 & 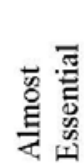 \\
\hline 1 & 2 & 3 & 4 & 5 & 1 & 2 & 3 & 4 & 5 \\
\hline 1 & 2 & 3 & 4 & 5 & 1 & 2 & 3 & 4 & 5 \\
\hline 1 & 2 & 3 & 4 & 5 & 1 & 2 & 3 & 4 & 5 \\
\hline 1 & 2 & 3 & 4 & 5 & 1 & 2 & 3 & 4 & 5 \\
\hline 1 & 2 & 3 & 4 & 5 & 1 & 2 & 3 & 4 & 5 \\
\hline 1 & 2 & 3 & 4 & 5 & 1 & 2 & 3 & 4 & 5 \\
\hline 1 & 2 & 3 & 4 & 5 & 1 & 2 & 3 & 4 & 5 \\
\hline 1 & 2 & 3 & 4 & 5 & 1 & 2 & 3 & 4 & 5 \\
\hline 1 & 2 & 3 & 4 & 5 & 1 & 2 & 3 & 4 & 5 \\
\hline 1 & 2 & 3 & 4 & 5 & 1 & 2 & 3 & 4 & 5 \\
\hline 1 & 2 & 3 & 4 & 5 & 1 & 2 & 3 & 4 & 5 \\
\hline 1 & 2 & 3 & 4 & 5 & 1 & 2 & 3 & 4 & 5 \\
\hline
\end{tabular}




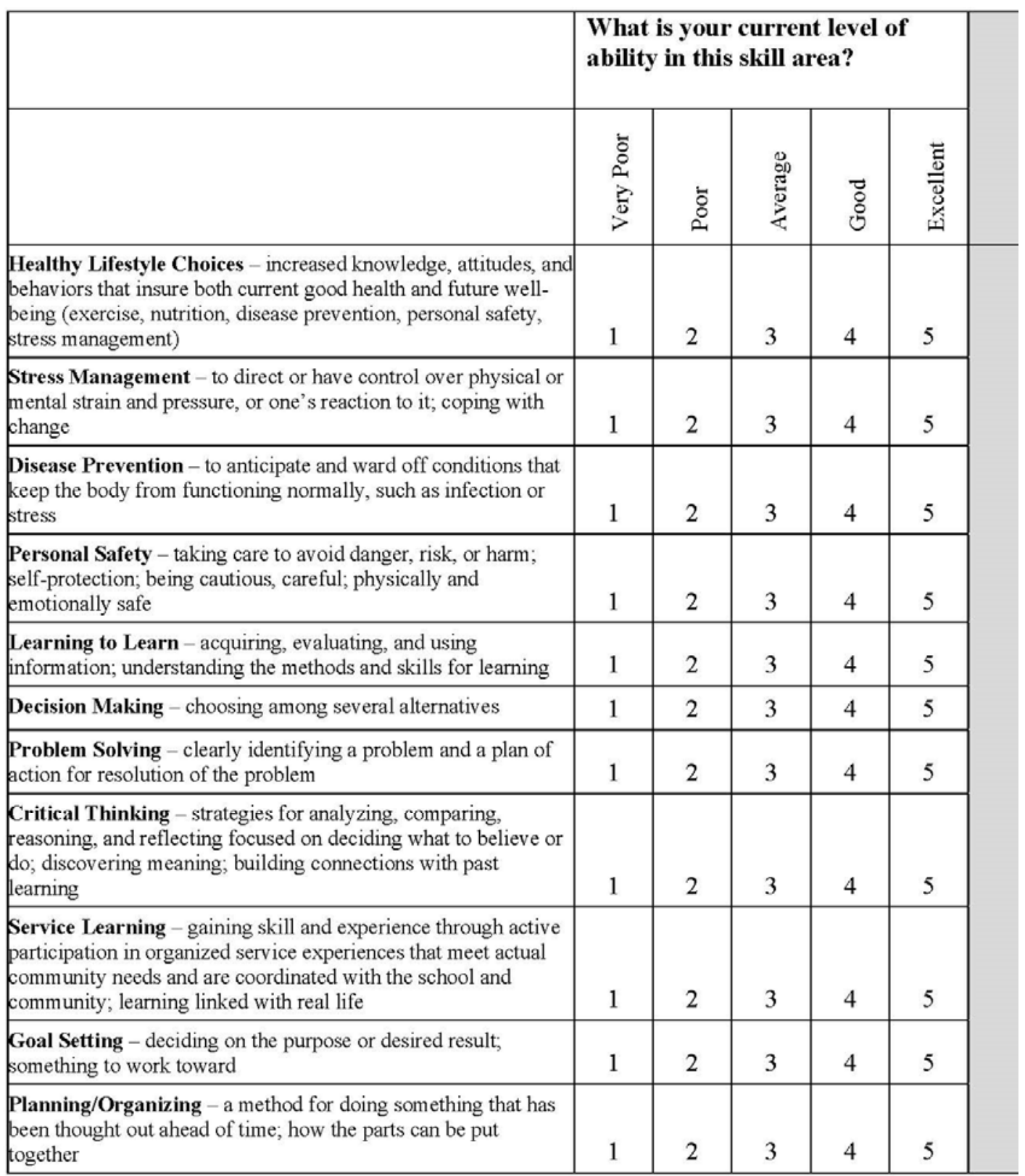




\begin{tabular}{|c|c|c|c|c|c|c|c|c|c|}
\hline \multicolumn{5}{|c|}{$\begin{array}{l}\text { How influential was participation } \\
\text { on } 4 \text {-H judging teams on your } \\
\text { development of each skill? }\end{array}$} & \multicolumn{5}{|c|}{$\begin{array}{l}\text { How important is this skill in your } \\
\text { current job? }\end{array}$} \\
\hline 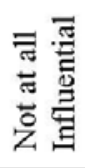 & 总䄈 & 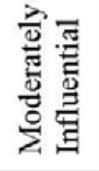 & 尝茎 & 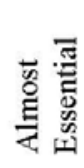 & 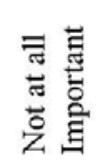 & 总䔍 & 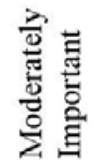 & 㤩 & $\begin{array}{l}\text { 焉 } \\
\text { 焉 } \\
\text { 离 }\end{array}$ \\
\hline 1 & 2 & 3 & 4 & 5 & 1 & 2 & 3 & 4 & 5 \\
\hline 1 & 2 & 3 & 4 & 5 & 1 & 2 & 3 & 4 & 5 \\
\hline 1 & 2 & 3 & 4 & 5 & 1 & 2 & 3 & 4 & 5 \\
\hline 1 & 2 & 3 & 4 & 5 & 1 & 2 & 3 & 4 & 5 \\
\hline 1 & 2 & 3 & 4 & 5 & 1 & 2 & 3 & 4 & 5 \\
\hline 1 & 2 & 3 & 4 & 5 & 1 & 2 & 3 & 4 & 5 \\
\hline 1 & 2 & 3 & 4 & 5 & 1 & 2 & 3 & 4 & 5 \\
\hline 1 & 2 & 3 & 4 & 5 & 1 & 2 & 3 & 4 & 5 \\
\hline 1 & 2 & 3 & 4 & 5 & 1 & 2 & 3 & 4 & 5 \\
\hline 1 & 2 & 3 & 4 & 5 & 1 & 2 & 3 & 4 & 5 \\
\hline 1 & 2 & 3 & 4 & 5 & 1 & 2 & 3 & 4 & 5 \\
\hline
\end{tabular}




\begin{tabular}{|c|c|c|c|c|c|}
\hline & \multicolumn{5}{|c|}{$\begin{array}{l}\text { What is your current level of } \\
\text { ability in this skill area? }\end{array}$} \\
\hline & $\begin{array}{l}5 \\
8 \\
2 \\
0 \\
0 \\
2\end{array}$ & $\stackrel{5}{8}$ & 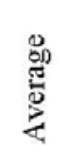 & $\begin{array}{r}7 \\
8 \\
0\end{array}$ & 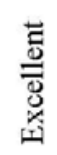 \\
\hline $\begin{array}{l}\text { Wise Use of Resources - using sound judgment; not wasteful; } \\
\text { being responsible; setting priorities }\end{array}$ & 1 & 2 & 3 & 4 & 5 \\
\hline $\begin{array}{l}\text { Keeping Records - recording selected useful information, } \\
\text { usually focused for a specific purpose }\end{array}$ & 1 & 2 & 3 & 4 & 5 \\
\hline $\begin{array}{l}\text { Resiliency - adaptability; the ability to recover after } \\
\text { experiencing misfortune or disease; coping with change; } \\
\text { overcoming problems and difficulties }\end{array}$ & 1 & 2 & 3 & 4 & 5 \\
\hline $\begin{array}{l}\text { Communication - exchange of thoughts, information, or } \\
\text { messages between individuals; sending and receiving } \\
\text { information using speech, writing, gestures, and artistic } \\
\text { expression }\end{array}$ & 1 & 2 & 3 & 4 & 5 \\
\hline $\begin{array}{l}\text { Cooperation - to work or act together for a common purpose or } \\
\text { mutual benefit }\end{array}$ & 1 & 2 & 3 & 4 & 5 \\
\hline $\begin{array}{l}\text { Social Skills - skills people use when interacting with others and } \\
\text { to behave in the accepted manner or customs of the society in } \\
\text { which they live; adapting well to one's social environment }\end{array}$ & 1 & 2 & 3 & 4 & 5 \\
\hline $\begin{array}{l}\text { Conflict Resolution - finding and applying creative and non- } \\
\text { destructive ways to resolve differences between people; getting } \\
\text { along with others }\end{array}$ & 1 & 2 & 3 & 4 & 5 \\
\hline $\begin{array}{l}\text { Accepting Differences - to recognize and welcome factors that } \\
\text { separate one person from another }\end{array}$ & 1 & 2 & 3 & 4 & 5 \\
\hline $\begin{array}{l}\text { Concern for Others - to worry about or give attention to the } \\
\text { well-being of others }\end{array}$ & 1 & 2 & 3 & 4 & 5 \\
\hline $\begin{array}{l}\text { Empathy - being sensitive to or identifying with another } \\
\text { person's situation, feelings, or motives }\end{array}$ & 1 & 2 & 3 & 4 & 5 \\
\hline Sharing - to have, use, or do together with another or others & 1 & 2 & 3 & 4 & 5 \\
\hline $\begin{array}{l}\text { Nurturing Relationships - two or more people forming a } \\
\text { connection that contributes to their mutual well-being, each } \\
\text { providing care and attention to the other person }\end{array}$ & 1 & 2 & 3 & 4 & 5 \\
\hline
\end{tabular}




\begin{tabular}{|c|c|c|c|c|c|c|c|c|c|}
\hline \multicolumn{5}{|c|}{$\begin{array}{l}\text { How influential was participation } \\
\text { on } 4 \text {-H judging teams on your } \\
\text { development of each skill? }\end{array}$} & \multicolumn{5}{|c|}{$\begin{array}{l}\text { How important is this skill in your } \\
\text { current job? }\end{array}$} \\
\hline 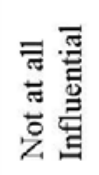 & 总焉 & 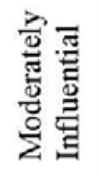 & 总竞 & 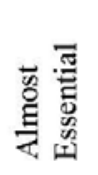 & 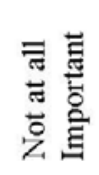 & 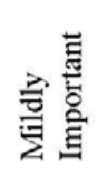 & $\begin{array}{l}\text { 总 } \\
\text { 焉 } \\
\text { 总产 }\end{array}$ & 忿 & 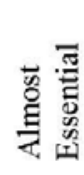 \\
\hline 1 & 2 & 3 & 4 & 5 & 1 & 2 & 3 & 4 & 5 \\
\hline 1 & 2 & 3 & 4 & 5 & 1 & 2 & 3 & 4 & 5 \\
\hline 1 & 2 & 3 & 4 & 5 & 1 & 2 & 3 & 4 & 5 \\
\hline 1 & 2 & 3 & 4 & 5 & 1 & 2 & 3 & 4 & 5 \\
\hline 1 & 2 & 3 & 4 & 5 & 1 & 2 & 3 & 4 & 5 \\
\hline 1 & 2 & 3 & 4 & 5 & 1 & 2 & 3 & 4 & 5 \\
\hline 1 & 2 & 3 & 4 & 5 & 1 & 2 & 3 & 4 & 5 \\
\hline 1 & 2 & 3 & 4 & 5 & 1 & 2 & 3 & 4 & 5 \\
\hline 1 & 2 & 3 & 4 & 5 & 1 & 2 & 3 & 4 & 5 \\
\hline 1 & 2 & 3 & 4 & 5 & 1 & 2 & 3 & 4 & 5 \\
\hline 1 & 2 & 3 & 4 & 5 & 1 & 2 & 3 & 4 & 5 \\
\hline 1 & 2 & 3 & 4 & 5 & 1 & 2 & 3 & 4 & 5 \\
\hline
\end{tabular}


8. What do you feel was the most useful attribute or skill you gained from participation in a 4-H judging program?

9. How many years were you a 4-H member (between the ages of 9 and 21)?

10. Please indicate how many years you competed on $4-\mathrm{H}$ judging teams at the local, state, and national levels.

\begin{tabular}{|l|l|l|l|}
\hline & \multicolumn{1}{|c|}{ Local } & State & National \\
\hline Livestock Judging & & & \\
\hline Poultry Judging & & & \\
\hline Dairy Cattle Judging & & & \\
\hline Forestry Judging & & & \\
\hline Horse Judging & & & \\
\hline Land Judging & & & \\
\hline Homesite Evaluation & & & \\
\hline Horticulture Judging & & & \\
\hline
\end{tabular}

11. What is your current age?

$21-25$

26-30

31-35

$36-40$ 
12. What is the highest level of education you have received?

Some High School

High School/GED

Technical School: Area of emphasis

Some College

Associate’s Degree: Degree earned

Bachelor's degree: Degree earned

Master's degree: Degree earned

Doctorate: Degree earned

Other Professional Degree (Dentist, doctor, lawyer, veterinarian, etc.):

Degree earned

13. In what type of work are you currently employed? (Please be specific)

14. Is your current position directly related to agriculture?

Yes

No

15. Do you want to spend the remainder of your career in your current position?

Yes

No (Please explain your ideal position) 


\section{Comments:}

If you have any questions about this survey, please contact:

Evan Anderson at eander13@mix.wvu.edu or

Dr. Deborah Boone at debby.boone@mail.wvu.edu or 304-293-5450.

\section{Thank you fox youx time!}


APPENDIX B

Initial Mailing Cover Letter 
February 27, 2014

Dear Past 4-H Judging Team Particpants:

As a past state 4- $\mathrm{H}$ judging team winner, you have experienced the importance of $4-\mathrm{H}$ in your life. 4-H judging teams teach youth about agriculture and help to develop many life skills individuals need to thrive and prosper as adults. In an effort to establish the effects of 4-H judging teams in members' lives, it is important we look to former 4-H members to gain their perspective of how 4-H has impacted their lives. To reach that goal, your assistance is vital.

My name is Evan Anderson, a graduate student at West Virginia University. I am working with my advisor Dr. Deborah Boone and Dr. Jean Woloshuk to conduct a study on lifeskill development among winners of state 4-H agriculture judging contests who went on to compete nationally between the years of 1995 and 2006. This study will attempt to gather information on the factors that encourage youth to join 4-H and participate on 4-H judging teams, life-skill development that may have occurred due to involvement in judging teams, and the importance of life skills on current careers. The results of this study will be used to prepare a thesis to partially fulfill the requirements for a Master of Science degree in Agricultural and Extension Education.

Participation in this research study is completely voluntary and all information you provide will be held as confidential as possible. The questionnaire should take approximately fifteen minutes of your time to complete. You may skip any question you do not feel comfortable answering and may stop at any point and submit a partially completed survey. You will notice a number at the top left-hand side of the return envelope. This number will be used to identify nonrespondents for follow-up mailings and will be destroyed before the data are analyzed. The results of this survey will be reported in a summary format and individual responses will be not be identifiable.

The Institutional Review Board (IRB) at West Virginia University has approved this study and the acknowledgement of this research is on file. If you have questions or concerns about completing the survey or participating in the study, please contact me at eander13@mix.wvu.edu or my advisor Dr. Deborah Boone at debby.boone@mail.wvu.edu or 304-293-5450.

Place the completed questionnaire in the enclosed postage-paid self-addressed return envelope and drop it in the mail. As an incentive, we will be drawing two names to each receive a $\$ 100$ Walmart gift card. If you would like your name to be included in the drawing, please fill out the slip included in this envelope and return it with your survey. Please return your completed survey by Monday, March 17, 2014. Thank you in advance for your participation in this study. We sincerely appreciate your time and assistance.

Sincerely, 
APPENDIX C

Incentive Opt-In Slip 
If you would like your name to be included in a drawing for one of two \$100 Walmart gift cards, please fill out the information below. Your participation in this drawing is optional, and all information received in relation to it will be destroyed once the drawing is complete.

\begin{tabular}{|l|l|}
\hline Name: & \\
\hline Address: & \\
\hline $\begin{array}{l}\text { City, State, } \\
\text { and Zip } \\
\text { Code }\end{array}$ & \\
\hline
\end{tabular}


APPENDIX D

Follow-Up Post Card 
Dear Past 4-H Judging Team Participant:

You were recently sent a questionnaire about your experiences as a former member of a West Virginia state 4-H judging team. If you have completed the survey thank you very much; it is critical to my research. If you have not yet filled out and returned the survey, please do so by April 30, 2014! Your input is very important and will help us to learn more about the impact that $4-\mathrm{H}$

judging teams have on participants' lives.

If you have questions or concerns about completing the survey or participating in the study, please contact me at eander13@mix.wvu.edu or my advisor Dr. Deborah Boone at debby.boone@mail.wvu.edu or 304-293-5450. Thank you for your assistance.

Sincerely.

Agricultural and Extension Education

P.O. Box. 6108

Morgantown, WV 26506 
APPENDIX E

Second Mailing Cover Letter 
$<$ Date $>$

Dear $<$ Name $>$,

Three weeks ago you were sent a questionnaire and we have not yet received a response. Your input is highly valuable as a past state $4-\mathrm{H}$ judging team winner.

4-H judging teams teach youth about agriculture and help to develop many life skills individuals need to thrive and prosper as adults. In an effort to establish the effects of 4-H judging teams in members' lives, it is important we look to former 4-H members to gain their perspective of how 4-H has impacted their lives. To reach that goal, your assistance is vital.

My name is Evan Anderson, a graduate student at West Virginia University. I am working with Drs. Deborah Boone and Jean Woloshuk to conduct a study on life-skill development among winners of state 4-H judging contests who went on to compete nationally between the years of 1995 and 2006. This study will attempt to gather information on the factors that encourage youth to join 4-H and participate on 4-H judging teams, on life-skill development that may occur due to involvement in judging teams, and on the influence participation in judging teams has on career choice and development. The results of this study will be used to prepare a thesis to partially fulfill the requirements for a Master of Science degree in Agricultural and Extension Education.

Participation in this research study is completely voluntary and all information you provide will be held as confidential as possible. The questionnaire should take approximately fifteen minutes of your time to complete. You may skip any question you do not feel comfortable answering and may stop at any point and submit a partially completed survey. You will notice a number at the top left-hand side of the return envelope. This number will be used to identify nonrespondents for follow-up mailings and will be destroyed before the data are analyzed. The results of this survey will be reported in a summary format and individual responses will be not be identifiable.

The Institutional Review Board (IRB) at West Virginia University has approved this study and the acknowledgement of this research is on file. If you have questions or concerns about completing the survey or participating in the study, please contact me at eander13@mix.wvu.edu or my advisor Dr. Deborah Boone at debby.boone@mail.wvu.edu or 304-293-5450.

Place the completed questionnaire in the enclosed postage-paid self-addressed return envelope and drop it in the mail. As an incentive, we will be drawing two names to each receive a $\$ 100$ Walmart gift card. If you would like your name to be included in the drawing, please fill out the slip included in this envelope and mail it with your survey. Please return your completed survey before $<$ Date $>$. Thank you in advance for your participation in this study. I sincerely appreciate your time and assistance.

Sincerely, 
APPENDIX F

Second Follow-Up Post Card 
Dear Past 4-H Judging Team Participant:

You were recently sent a questionnaire about your experiences as a former member of a West Virginia state 4-H judging team. Due to a mailing glitch the deadline for its return has been extended to April 8, 2014. If you have not yet filled out and returned the survey, please do so! Your input is very important and will help us to learn more about the impact that 4-H judging teams have on participants' lives.

If the person to whom the packet was addressed no longer lives at this address, please forward to them or send us their current address. If you have questions or concerns about completing the survey or participating in the study, please contact me at eander13@mix.wvu.edu or my advisor Dr. Deborah Boone at debby.boone@mail.wvu.edu or 304-293-5450. Thanks you for your assistance.

Sincerely.

\author{
Agricultural and Extension Education \\ P.O. Box. 6108 \\ Morgantown, WV 26506
}




\section{APPENDIX G}

Responses to Open-Ended Questions 
Note: The use of brackets [ ] denotes where an individual's name was redacted.

Other individuals who influenced joining 4-H and 4-H judging teams.

Neighbor

neighbor

FFA Advisor

Teacher from another school

Farm

Show livestock at fair

Wanted to show livestock at the county fair

older/former 4-Hers

Other individuals who taught the skills needed for 4-H judging.

Neighbor [WVU Extension Agent]

neighbor

individuals I show with

Judging coach

Judging Coach

[Instructor]

Volunteer

Community members

Community members

County Judging Coach/Collegiate Coach/Area Dairy Farmers

FFA Advisor

Teacher from another school / family friend

Team coaches (parent volunteers) also members of the WVU collegiate judging team

Judging Coach, was NRCS employee

Soil Scientist/Community Leader

Forester

[WVU Professor]

Horse trainer

Horse Trainer

guide books, horse riding instructor

Coach (Judging Team)

Retired Extension Agent

Volunteers who hosted our group @ their farms.

former 4-Hers

Past 4-H member that coached out judging team.

Land judging coach - Soil Scientist

Land Judge Coach 


\section{Consequences for missing judging team practice prior to state judging events.}

additional menial labor

can't remember

Why belong if you can't make practice

Teacher was disappointed

But we never missed.

Verbal assault

Could potentially lose your position if there were more than one team.

If you were not accountable for your attendance or keeping up w/reasons you could be

kicked off the team

Sometimes owed an extra set of reasons

learning valuable info pertaining to the judging

I did poorly in competition

Your spot on a team could be taken by another member.

You didn't win

not making team

I don't think we were allowed to go to the competition

often participants did not align w/ team requirements failure to attend practice would put

you on the incomplete team/ individual competition

Important knowledge missed

You may loose [sic] your place on team to alternate

There was not a formal punishment, but missing judging practice had an effect on

judging performance.

Risk of not getting enough experience to make the team

I don't remember but I am sure we were strongly encouraged to attend

\section{Most useful attribute or skill gained from participation on a 4-H judging team.}

small team dynamics; dependability; teamwork

teamwork

social/communication skills - speaking in front of people

Attention to details

leadership

Critical Thinking

Learning to engage and meet new people.

Knowledge of land classes

Public Speaking/Self Confidence

Communication

Participating in judging helped me overcome my fear of public speaking

critical thinking skills

Value of hard work

Travel and dealing with other people closely

Self-esteem - Self accomplishment 
Getting out and being involved, learning how to communicate with other people Teamwork, cooperation, gaining self-confidence through learning \& striving.

Working with a group

Leadership, public speaking

How to interact with people

Being goal oriented

Cooperation

Conviction of one's own decisions

Learning to Learn

The ability to gain knowledge, apply it, and teach it

Teamwork

Confidence - Building my own voice \& expressing it.

public speaking confidence

By far it was public speaking (oral reasons)

Team work

Problem solving \& being able to make quick, accurate decisions

Knowledge of farming and Food for Farm

Team building, communication, conflict resolution

Discipline from practicing

A sense of belonging

I don't remember much from that time, but I am sure my speaking skills improved slightly.

Broadening my horizons, being open to travel \& move around

The ability to think things through

Study Skills

independent learning; ability to read, understand and apply

Public Speaking

Teamwork/Group Effort

teamwork

Exposure to differences \& similarities

Self-motivation

Communication, team building

Forming my own opinion and backing up that opinion w/facts \& observations

Public speaking skills, Communication skills

Team work

Hard work and dedication

Self Confidence

communication skills, leadership qualities

competition at different levels, performing under pressure

Self Confadience [sic]

Not second guessing choices

Decision Making

You get to enteract [sic] with others

Critical Thinking

Work ethic

Critical Thinking 
The smallest detale [sic] counts

teamwork

Team work

Social Skills

Teamwork, communication, decision making

Public speaking

Self-discipline

Team work

Team work \& sharing information

Public Speaking (Speaking in front of someone)

Communication - overcome fear w/others (talked to strangers)

Decision making / critical evaluation

Public speaking

Teamwork

evaluation of stock \& public speaking

Sense of pride in accomplishments.

Teamwork \& Self Motivation

learning to do public speaking

Social interaction

General knowledge of Horticulture - influenced my future career interests

Teamwork; improving skill/ability for the good of the judging team.

working as a team; practice makes perfect

Quick decision-making - identifying attributes, prioritizing (both what to work on next, \& individual items)

Decision Making

Team work

Responsibility for self and others

Friendship, having measurable goals - studying, practicing and winning

Confident decision making

Collecting my thought and putting into meaningful reasons

Public Speaking, Decision Making

The ability to share the knowledge I gained with others.

Public speaking - Oral Reasons

teamwork, leadership, \& social skills

people skills

Social skills

teamwork

Quality of products you produce

Knowledge, public speaking

Lifelong friendships, studying/practices and seeing winning results

Helped me when I got into the poultry industry

Decision Making

Giving Reasons Public Speaking

Decision Making

Dedication

ability to communicate thoughts - visions 
Working together

The ability to learn new skills and master those skills.

Learned ecology, farming, house considerations

Learning to set goals, work for them and achieve them.

Communication

\section{Highest degrees earned.}

Master of Science / management

MA education

Reading Specialist

Systems Engineering, M.I.T.

Med

Animal \& Nutritional Sciences

Pharmd (Pharmacist)

Animal Science Crop \& Soil Science / VA. Tech

MBA

Communication - 2004

Animal Science \& Criminal Justice

DVM

Business

Forestry

Ag. Business

Animal \& Poultry Science

Natural Resource Mgmt.

Doctor of Osteopathic Medicine/Physician

MS Speech Language Pathology

Doctor

Forestry Science

DVM

Pursuing degree in educational administration

Doctor of Osteopathy (D.O.)

Safety Management

Bachelor's Science of Nursing

Bachelor of Science in Agriculture/Animal \& Vet. Science

BA in EL ED

Animal \& Nutritional Science

Ag Science

social work

BA Urban Policy \& Planning

Msc. Social Anthropology

BS CpEEE Ms CS

B.S. Ag Business

BS in Biology

AAS, Veterinary Technology 
B.S. Ag. And B.A.

Integrated Marketing Communications

Masters of Ag. \& Extension Ed

DVM

MS - Economics (WVU)

X-ray tech \& LPN

R.B.A. Crime \& Society

Highway maintenance, hobby farmer

Elementary Education

Doctor of Pharmacy (PharmD)

Criminal Justice

Agriculture

Public Administration

DPT

Agriculture

2008 BS in Agriculture

associates in natural science / associates in Education

Safety Management

BA degree

Business Admin - Accounting

Animal \& Nutritional Sciences

of Science in Ag. w/major in Ag \& Environmental Ed., Animal \& Nutritional Sciences

and minor in Ag Business Management

Animal \& Nutritional Science

CAN

Agriculture Science

History (WVWC)

Animal Science from WVU

Agriculture

Horticulture

Political Science/ Legal Studies

Masters of Occupational Therapy

Rural medicine; family practice

MBA

Bachelor of Science in AGEE

Elementary Ed./Leadership studies

Business Technology

Juris Doctorate

Masters of Agribusiness

Professional Accountancy

BS

B.S. of Dental Hygiene

Animal and vet science

Auto mechanics

Animal and Poultry Science

Ag equipment technition [sic] 
Master of Accounting \& IT / Master of Ag. Forestry \& Consumer Sciences

Animal \& Nutritional Sciences

Agribusiness Management

MS in Crop \& Soil Science at UGA

Social Work \& Public Administration

B.S. Animal Science

$\mathrm{PhD}$ Chemical Engineering

Bachelor of Science in Animal Science.

Doctor of Veterinary Medicine

\section{Current type of work.}

Banking

teacher

Teacher

Investment Management

Educational Consultant

Feed Mill Quality Assurance in a vertically integrated poultry company

CVS Retail Pharmacist

Production Ag - Cash Crops \& Beef Cattle \& Seed Production

Education Publishing Sales

Executive Producer - Television News

Communications officer @ a sheriff's dept (911 dispatcher)

Veterinarian

truck driver

Emergency Room RN

Construction

Avigen Turkeys Inc. Lab Tech

Farming

Forestry Technician (Recreation)

Electrical Construction

Resident Physician in Family Medicine

Speech therapist at an elementary school

Physician

Extension Education

Veterinarian

Chemical technician

4-5 grade teacher

Maternal-Child Health Physician

Health Care - Registered Nurse

Stay at home mom

Teacher

Optician at eye doctors office (nothing available in my field)

School bus driver

Veterinary Technician 
Social Worker

City Planner - City of Charles Town

Early Childhood Education (Early Head Start Teacher) / out of state

Software Engineering

Animal Nutritionist

Electronics

Pharmacy Technician

not employed, but manage my own private horse farm

Federal Government - Treasury Dept. Inspector General's Office of Counsel (Legal

Advice to Internal Investigations/Auditing)

Direct sales/stay at home mom

Ag Ed Teacher

Production Agriculture

Cost Analyst supporting the US Navy

Health Care Manager

Oil \& Gas

Currently a Cash Office Associate/Keyholder at Belk Dept. Store

I am a legal assistant for the Randolph County Prosecuting attorney's office and the Magistrate Court coordinator

4th Grade General Education Teacher

retail pharmacist

Armed Security Guard

I am currently disabled due to Chrone's disiese [sic]

WVU Extension Agent

Stay home mom

Physical Therapist

Forman for a Corporation Building Natural Gas Compressor Station

Dairy \& Beef Farmer

oil field (lab \& MET \& Tech)

Banking

Healthcare, nursing assistant / Nursing School Student

Safety, Compliance \& Training Manager in Coal Ind.

Agricultural teacher

Grad school student in Ministry

Staff support - legal

Landscaping/Horticulture

Masters Student Animal Physiology at WVU

Biology Technician for Physiology Dept at WVU Medical Bio Research

State Extension Livestock Specialist/Assistant Professor

unemployed due to having another baby

Supervisor for construction company

Assist living/Dementia unit

Veterinary Assistant/ Artificial Insemination tech for cattle

Federal Law enforcement Dept. of Justice

Animal Processing Facility - Supervisor

construction \& mechanics 
Teaching instructor

Law Enforcement Officer

West Virginia Department of Agriculture - Forest Health

Geospatial analyst/ human geographer

I'm an Occupational Therapist at a nursing home.

Medical doctor working in (Martinsburg) Berkeley Medical Center and Jefferson

Memorial

Beer Brewing, Restaurant Management

WV Supreme Court - South Branch Valley Drug Court Adult Probation Officer

Material Handler at RR Donnelly

3rd Grade Teacher

Office Assistant - Supreme Court

Judicial Clerk

Marketing department w/an insurance company

Accounting. I have my CPA.

7th Grade Science Teacher

Health Care - Public Health - Dentistry

Broiler Service Tech - Pilgrim's

cabinetry

Construction/farming

Agricultural supply and feed mill technician

Farm \& Trucking

Owner \& Operator of Beef and Grain Farms

1. Part-time Sanitarian/Health Inspector at County Health Dept. - Complete food rest. Insp., collect water \& milk samples, issue permits for wells \& septics for new homes, investigate rabies 2 . Stay at home mom with 2 children 3. Cattle and Sheep Farmer

Cattle farm, manage a poultry farm

Compliance Officer

West Virginia Conservation Agency

Owner/Agent - State Farm Insurance / Co-Owner - Bar H Cattle

Finishing up MS, looking for $\mathrm{PhD}$ programs

Dairy Farm operation / Herd Manager

Wellness coach

Dairy Feed Sales/ Nutrition

University Professor

Department of Defense contractor/finance

Jr. Research Specialist

\section{Ideal jobs.}

stunt man

Want to work more directly with students again

management within current organization

Wish to Farm for Myself In the Future

Not For Profit Admin. 
Not sure at this point but I would like to find a position that allows me to get back to my agriculture roots

police officer \& farmer

Buy timber for a sawmill

Would like to find a job with my degree and to be out with people more

Plan to complete training and advance in career

4-H extension agent or Full time farmer

Recently accepted into Family Nurse Practitioner Program, plan to pursue a career as an FNP

My kids are very young now but I imagine that when they are older I would like to work for USDA Farm Service Agency, NRCS, Farm Bureau, Farm Credit, or some other Agriculture-related position.

Would like to find a career more closely related to my degree

I want to work in an environmental type area, I enjoy planning but I don't currently get to work with environmental aspects, issues or planning

I'd like a position with more room for initiative and integration of gardening and other science into the curriculum.

Research in a lab

Commissioner at the Commodity Futures Trading Commission

Non-profit marketing/development

Training Horses

I would prefer to be a farmer $=$ )

I want to eventually become a K-9 operator

WVU Extension Agent

Own my own business

Stay home mom \& farm

plan to get into the library as a Library Media Specialist

Would like a Masters and work in research with plants.

Professor in Animal or Dairy Science

No sure. My job is based on research grants. However, my job will/is hard on my health physical \& mental.

would love to stay home with my kids but need to work to support them

Farming Full Time

I would like to be more directly involved in farming. Ideally a farm consultant.

Gain a leadership position, or education/training

Would like to move up in company

owning own business

Numerous reasons - low pay! Would like to remain in Forest Health field

Entrepreneur in Fermented Beverages

A leadership position

Pursue Principal position

Queen of a small island nation. Actually - I am undecided.

Mid-level Provider - PAC

Research agronomist

Working as a large animal veterinarian 
APPENDIX H

Comments 
Just kidding about the stuntman thing, but I don't know what I want to be when I grow up. At this point, I will likely stay in the finance field.

Thanks for your interest in the topic and for following up with us. I'm happy to chat further if you like.

Hope my information was helpful. Good luck as you complete your Masters Program.

I know this will be later than March 17th because I didn't receive it untill [sic] the 18th but try to help you out anyways. Judging was the best experience in 4-H by far. I would recommend it to any 4 -Her

4-H as a whole played an enormous part in shaping my life and forming me as a responsible adult. I am grateful for the exposure to new places, people, cultures, and activities participating in events like judging competitions provided.

Sorry for the delay in getting this back. I hope you can still use it. 4-H and judging played an important role in helping shape me.

I'm not sure if I gave you the exact \# of yrs for the yrs competed in judging. It's been a while, sorry. Best of luck!

I received this survey on March 20, 2014. Due to the mail service this probably will not help you.

Thanks for letting me be a part of this!

Dairy judging is an excellent avenue for teaching and re-inforcing [sic] life skills such as decision making, self confidence, and team membership. I will always look upon my judging experiences fondly and be grateful for the opportunities afforded to me as a judging team member. Winning is not everything, it is the road to competition that leaves the lasting impression.

It was my involvement in 4-H that led me into education as well as helped me maintain and manage 300 cows. I feel that 4-H and 4-H Judging provides life skills for young people for the common good. Sincerely,

Judging was a great introduction to career paths \& schools (colleges). It brought me more life lessons \& team building experience than what I thought it would - I was learning without being aware of it at the time. Also, the exposure of different cities \& cultures impacted me in such a way that it influence me to be more comfortable to try new things. 
As I was answering the questions I had a little bit of trouble differentiating in my mind between my memories of 4-H judging teams and FFA judging teams. The two seem to run together at times.

I enjoyed every minute I spent on judging teams (high school \& collegiate) \& am very grateful I had the opportunity \& support to do so!

Very well thought out survey but could have been a little more concise. Shortening it a bit may get you more back. $=$ )

My best wishes for your work and the future of 4-H Judging Teams in West Virginia. Not a lot of judging team opportunities were available in my county. I would have liked more opportunities.

I was a reluctant participant because my parents forced me to be part of the team. My dad was a coach, but I didn't want to look at another dairy cow. I enjoyed the travel to Nationals and the ag technology I saw along the way. But I didn't really care about the competition, and that part was a waste of my time.

Biggest benefit of judging was getting exposed to new people, distant places, and a better understanding of how much bigger the world was than WV.

Question \#3 - better word choice for me would be intense. Overall, I had difficulty differentiating what skills/qualities I developed from being a member of a judging team versus a $4-\mathrm{H}$ member in general.

Dairy judging is a tremendous experience for youth. Oral reason participation, travel, \& exposure to new ideas, etc. are all positive benefits. The skill of dairy judging is important but please consider how the National Dairy Challenge has evolved to offer the same skills on a greater level of thinking and reasoning. I do not believe 4-H as a whole is as strong as it once was and that is unfortunate. Too much emphasis is placed on livestock exhibitions and less emphasis on project books. Please look at how other states have transformed their 4-H agricultural programs to better capture the open mindedness of the youth so they can participate in personal growth and better adjust to society to make positive contributions. Keep providing opportunity and the cream will keep rising to the top. None of my comments are meant to be negative to numerous positive benefits 4- $\mathrm{H}$ has provided over the years but 4- $\mathrm{H}$ must continue to adapt for today and tomorrow.

After I was too old to be a 4-Her I became a project leader for at least 4 more years with the market rabbit/chicken projects, and then on to be an all-star. 4-H has overall been the most influential in my life. I would never have had the confidence, the leadership skills, or the desire to learn and teach, without this program. I can never thank all those who supported me, and taught me, enough. Thank for choosing me to participate in your study.

Had a wonderful time with wonderful people 
Being on the team, especially preparing for the National Level was extremely tough and I had to put in a lot of work however it was some of the most amazing experience of my childhood. "three \& won"!

We would love to see results. We currently have are children in 4-H. Good luck Evan =)

I judged dairy cattle throughout my 4-H years and 1 year in college. I enjoyed the experience especially getting to see the different dairy operations and facilities

Good luck with your research. My involvement in judging teams was not as important to my life as 4-H in general was. Young people underestimate the number of doors 4-H can open for their future.

Thank you for contacting me about your study! I look forward to the results \& publication.

Noted 2 years participation each in FFA local and state dairy products judging, land judging, and homesite evaluation. Noted an associate's degree "Asso. Of Arts Degree in Ag. Ag \& Environmental Ed." Noted position is directly related to agriculture - "I work w/sheep - study the pituitary"

I really miss being in 4-H. But still get to have fun with it my kids are in 4- $\mathrm{H}$ and clover buds now

4-H was the best years of my life and being on the judging team made it even better. Meeting people from across the country

4-H was and is important I enjoy my time in and will encourage my daughter to join

Sorry this is late - was mailed to my parents address.

My current address: [ ] Please feel free to contact me for additional comment/input. Horticulture judging was a highlight of my 4-H experience and of my life. And thank you for sending me this survey!

I enjoyed being in 4-H. The life skills \& social skills I have today have been molded by my entire 4-H experience as a whole rather than just my judging team experience.

I have so many memories re: 4-H experiences and has been highly influential; I'll carry on the tradition w/my children. I can't say enough good things about what 4-H did for me and my siblings

Thank you for contacting me for this, I apologize for the delayed response. Being on a $4-\mathrm{H}$ judging team was fun \& a good learning experience. Please contact me should you need any more info.

Some of my best memories as a child are related to 4-H and FFA. Growing up on the family farm and having responsibilities taught me a lot about life. Having the experience 
to show livestock for 4-H and FFA at the fair and building friendships has helped me to be a well rounded person and develop who I am today.

My survey was not delivered until 3-17-14. Hope this helps. Good Luck!

Some of my best memories as a child come from 4-H and FFA. Growing up on a farm teaches responsibility and life lessons. Good things come to those who work hard, put in long hours, show dedication and determination. Judging teams and showing livestock were very important in my life while growing up. I am looking forward to seeing my children involved in agriculture activities in the near future with 4-H as well as FFA.

I also participated in FFA judging contests for 4yr of high school. Livestock, poultry, and homesite. Went to national 1yr in Poultry Judging and several yr of state contests for the others. Gave me the chance to see a lot of the country and meet a lot of people.

4-H and 4-H Activities help build \& develop life-long skills in many sectors of life. Best of luck on your research! 
VITA

Evan H. Anderson

Education:

Professional

Experience:
May 2003

August 2014

May 2008

June 2008 -

March 2009

March 2009 -

October 2010

March 2011 -

October 2011

May 2012 -

August 2012

August 2012 -

May 2014
Bachelor of the Arts

Psychology

Goucher College

Baltimore, MD

Bachelor of Science

Horticulture

West Virginia University

Morgantown, WV

Master of Science

Agricultural and Extension Education

West Virginia University

Morgantown, WV

Intern

West Virginia University

Organic Research Farm

Morgantown, WV

Greenhouse Assistant

West Virginia University Greenhouse

Morgantown, WV

Farmer - Owner/Operator

Provider Gardens CSA LLC

Morgantown, WV

Contracted Horticulturalist

Potomac Headwaters RC\&D

Martinsburg, WV

Plant Pathology Assistant

West Virginia University

Morgantown, WV

Graduate Assistant

West Virginia University

Agricultural \& Extension Education

Morgantown, WV 